\title{
Making the Most of Mentors: Recruitment, Training, and Support of Mentors for Adolescent Girl Programming-Toolkit
}

Miriam Temin

Population Council

Eva Roca

Follow this and additional works at: https://knowledgecommons.popcouncil.org/departments_sbsr-pgy

Part of the Family, Life Course, and Society Commons, and the Gender and Sexuality Commons How does access to this work benefit you? Let us know!

\section{Recommended Citation}

Temin, Miriam and Eva Roca. 2019. "Making the Most of Mentors: Recruitment, Training, and Support of Mentors for Adolescent Girl Programming-Toolkit." New York: Population Council. 


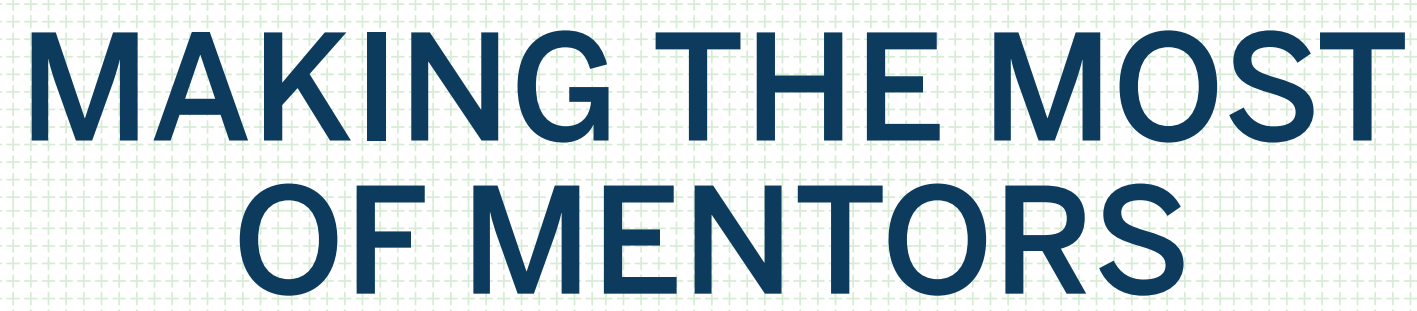

Recruitment, Training, and Support of Mentors for Adolescent Girl Programming 
The Population Council helps strengthen the capacity of different actors to design, implement, and evaluate effective, scalable programs that build the health, social, economic, and cognitive assets of adolescent girls. We work with institutions that range from large multilateral and bilateral organizations and governments to small community-based organizations and national networks.

The Population Council is committed to expanding programming on the ground for girls, anchored in evidence, in partnership with community practitioners, and with the needs of specific segments of girls at the center.

For more information on evidence-based approaches to adolescent programming and an overview and links to tools and videos, please visit: popcouncil.org/girl-centered-program-resources.

Suggested citation: Population Council. 2019. Making the Most of Mentors: Recruitment, Training, and Support of Mentors for Adolescent Girl Programming. New York. 


\section{Contents}

Acknowledgments

Page 2

Acronyms 3

Why Are Mentors Important to Adolescent Girl Programming? $\quad 4$

$\begin{array}{ll}\text { Mentor Profile, Recruitment, and Compensation } & 7\end{array}$

Mentor Training and Retention 23

Forming Community-based Groups and Delivering Core Content 77

$\begin{array}{ll}\text { Monitoring and Evaluation } & 103\end{array}$

$\begin{array}{ll}\text { Models of Sustainability } & 127\end{array}$

Appendices 131

Frequently Asked Questions $\quad 132$

Population Council Program Descriptions 135

Links to Full Curricula from Programs Included in Mentor Toolkit $\quad 139$

Additional Resources and Readings $\quad 141$ 


\section{Acknowledgments}

This Mentor Toolkit was produced by Eva Roca and Miriam Temin, with substantive input from Natalie Jackson and additional contributions from Karen Austrian. Our deep thanks to the staff of the many Population Council programs who provided insights and materials for this toolkit. The materials were originally used in:

- Abriendo Oportunidades (Opening Opportunities)

- Adolescent Girls Empowerment Program (AGEP)

- Adolescent Girls Initiative-Kenya (AGI-K)

- Bangladesh Association for Life SKills, Income, and Knowledge for Adolescents (BALIKA)

- Biruh Tesfa (Bright Future)

- Filles Eveillées (Girls Awakened)

- GirlsRead!

- Nisikilize Tujengane (NISITU) (Listen to Me, Let's Grow Together)

- Safe and Smart Savings

Particular gratitude goes to the members of the Mentor Toolkit Advisory Group: Sigma Ainul, Sajeda Amin, Karen Austrian, Kamruzzaman Bhuiyan, Ludivine Cicolella, Annabel Erulkar, Cecilia Garces, Pamela Nyirenda, Mercy Nzioki, and Silvia Tum. We also thank the members of the Adolescent Girls' Programming Community of Practice and many others who contributed to developing the resources included here. 


\section{Acronyms}

$\begin{array}{ll}\text { AGEP } & \text { Adolescent Girls Empowerment Program } \\ \text { AGI-K } & \text { Adolescent Girls Initiative-Kenya } \\ \text { AO } & \text { Abriendo Oportunidades (Opening Opportunities) } \\ \text { BALIKA } & \text { Bangladeshi Association for Life Skills, Income, and Knowledge for Adolescents } \\ \text { FAWEZA } & \text { Forum for African Women Educationalists of Zambia } \\ \text { FE } & \text { Financial Education } \\ \text { GBV } & \text { Gender-based Violence } \\ \text { HIV/AIDS } & \text { Human Immunodeficiency Virus/Acquired Immunodeficiency Syndrome } \\ \text { HR } & \text { Human Rights } \\ \text { MCPs } & \text { Multiple Concurrent Partnerships } \\ \text { NGO } & \text { Nongovernmental Organization } \\ \text { NISITU } & \text { Nisikilize Tujengane (Listen to Me, Let's Grow Together) } \\ \text { SRH } & \text { Sexual and Reproductive Health } \\ \text { SS } & \text { Safe Space } \\ \text { STIS } & \text { Sexually Transmitted Infections } \\ \text { TOT } & \text { Training of Trainers } \\ \text { VAWG } & \text { Violence Against Women and Girls }\end{array}$




\section{Why are mentors important to adolescent girl programming?}

Community-based programs for adolescent girls are increasingly centered around clubs or groups. Programs delivered using this approach, sometimes called "safe spaces," use mentors to support girls to build assets'-such as valuable relationships, skills, and knowledge-and to prepare them to make and act on decisions about their lives. Effective programs have linked girls to friends and mentors, and enabled them to access resources.

For decades, the Population Council has been conducting and testing programs in different regions using this model. A growing body of evidence shows that assetbuilding can boost girls' life chances by improving their health, educational status, livelihoods, and safety.

Mentors are an important part of many effective programs for girls, yet little information is available about the practical aspects of developing and supporting a successful mentor cadre. Perceptions about girl-group mentors and their roles vary tremendously. The definition of a mentor's role will depend on the goals and ambitions of the program. Some programs aim to deliver basic skills and information; mentor roles in such programs may center on creating an engaging environment for participants to learn and apply the material. Other programs strive to create wide-ranging change in community norms about girls and gender; mentors in these programs may be expected to conduct activism and deep community engagement in their role as change agents.

In response to the evolving evidence base and to help inform program practices, the Population Council has developed tools to support different aspects of groupbased programming for girls that has a particular emphasis on mentoring. Many recommendations in this toolkit are based on proven strategies. However, it is worth noting that while these tools are often used in the context of studies and evaluations, impact evaluations have not tested different approaches to mentoring in isolation from other program elements. Nevertheless, the aspects of mentoring

\footnotetext{
1 "Assets" are the human stock girls use to reduce risk and expand opportunity. Social assets include trusted relationships with others; cognitive assets include problem solving skills; economic assets include budgeting skills; and civic assets include identity cards. An asset-building approach considers the whole girl rather than building her skills in one sector. For more information: https://ssir.org/articles/entry/how_to_give_adolescent_ girls_voice_choice_and_control
} 
described here were all featured in programs that underwent impact evaluations and were generally found to have positive effects on girls.

The content of this toolkit comes from a variety of Population Council programs. It includes materials from community-based group programs for girls aged 7-24 years. The resources presented here were developed and adapted for use in countries around the world, including Bangladesh, Burkina Faso, Ethiopia, Guatemala, Kenya, Mexico, and Zambia; in both urban and rural contexts; and with in- and out-of-school girls, married girls, girls in domestic work, and others. Specific details about the programs and links to the resources are provided in the Appendices. While these programs focused on girls who were often underserved by "youth" programs in their communities, the tools can also be useful for other types of programs, for example those that work with boys' and girls' groups that use mentors.

This toolkit is designed to be practical and user-friendly for program planners, practitioners, mentor trainers, and mentors themselves. It includes insights from years of Population Council experience, pulling together lessons, tips, and specific tools that can be adapted and used to find, train, monitor, support, and evaluate mentors. Inside the toolkit you will find:

- Experiences from the Population Council's decades of work in adolescent girl programming

- Mentor recruitment and training strategies

- Exercises used by mentors to facilitate program sessions

- Mentor-retention strategies

- Monitoring and evaluation tools

- Models for sustainability

The information provided in this toolkit is grouped into four main content types:

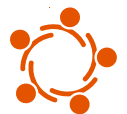

Activities are actions, presentations, and games that can be used during a program session or a mentor training.

Case Studies describe how Population Council programs use mentor resources.

(25) Guides provide insights and context.

Tools are forms, agendas, and templates that can be adapted to a program's needs. 
Each resource also identifies one of three primary users: program planner, mentor supervisor, or mentor. However, many of the resources will be applicable to more than one user group. Most essential, all resources contained in the toolkit are intended to be used as examples that users can adapt for the context where they work. Adaptations to local needs, languages, and illustrative examples also may be warranted. A key step is for users to understand the relevance of each resource-not only the aims of the specific activity or tool, but also how it is relevant to girls' lives.

The purpose of this toolkit is to share materials that can be adapted to fit the needs of different programs. We encourage users to photocopy individual pages and modify them by hand if only minor changes are needed. For more extensive customization, users may copy content and build upon the material by adding program logos and modifying the text to fit the needs of specific programs. Editable files of the tools found in this toolkit may be downloaded at https://knowledgecommons.popcouncil.org/departments_sbsr-pgy/630/ Please credit the Population Council when using any of these materials.

For more information on evidence-based approaches to adolescent programming and an overview and links to tools and videos, please visit: popcouncil.org/girl-centered-program-resources. 


\section{CHAPTER 1}

\section{Mentor profile, recruitment, and compensation}

\begin{tabular}{llr} 
GUIDE & The Mentor Model & Page 10 \\
GUIDE & Mentor Selection Criteria & 12 \\
GUIDE & Mentor Recruitment & 13 \\
TOOL & Mentor Advertisement & 14 \\
CASE STUDY & Adolescent Girls Empowerment Program: Mentor Recruitment & 16 \\
GUIDE & Recruitment: Interview and Selection & 17 \\
TOOL & Mentor Interview Score Sheet & 19 \\
TOOL & Mentor Service Contract & 20 \\
GUIDE & Mentor Compensation & 22 \\
& & \\
\hline
\end{tabular}




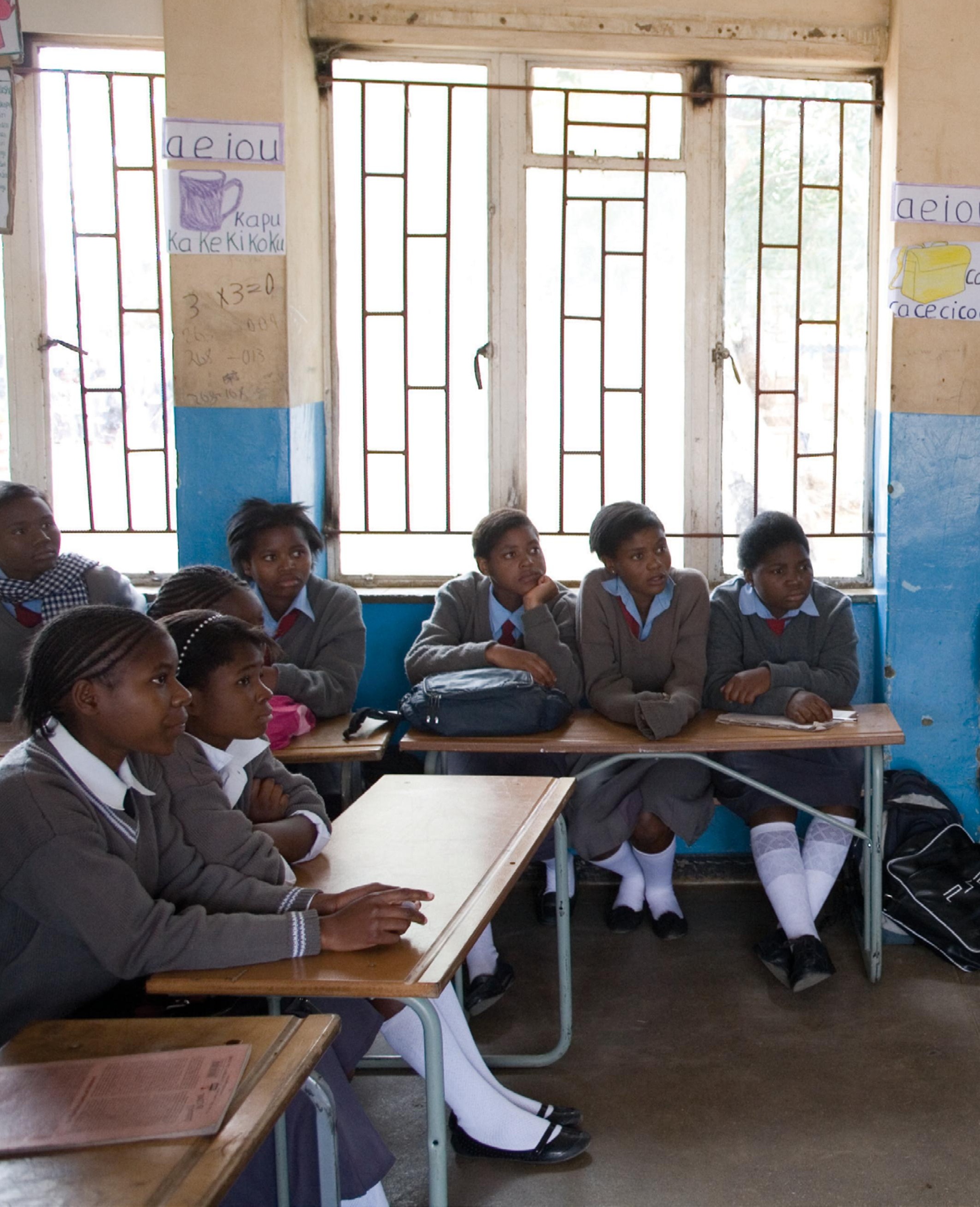




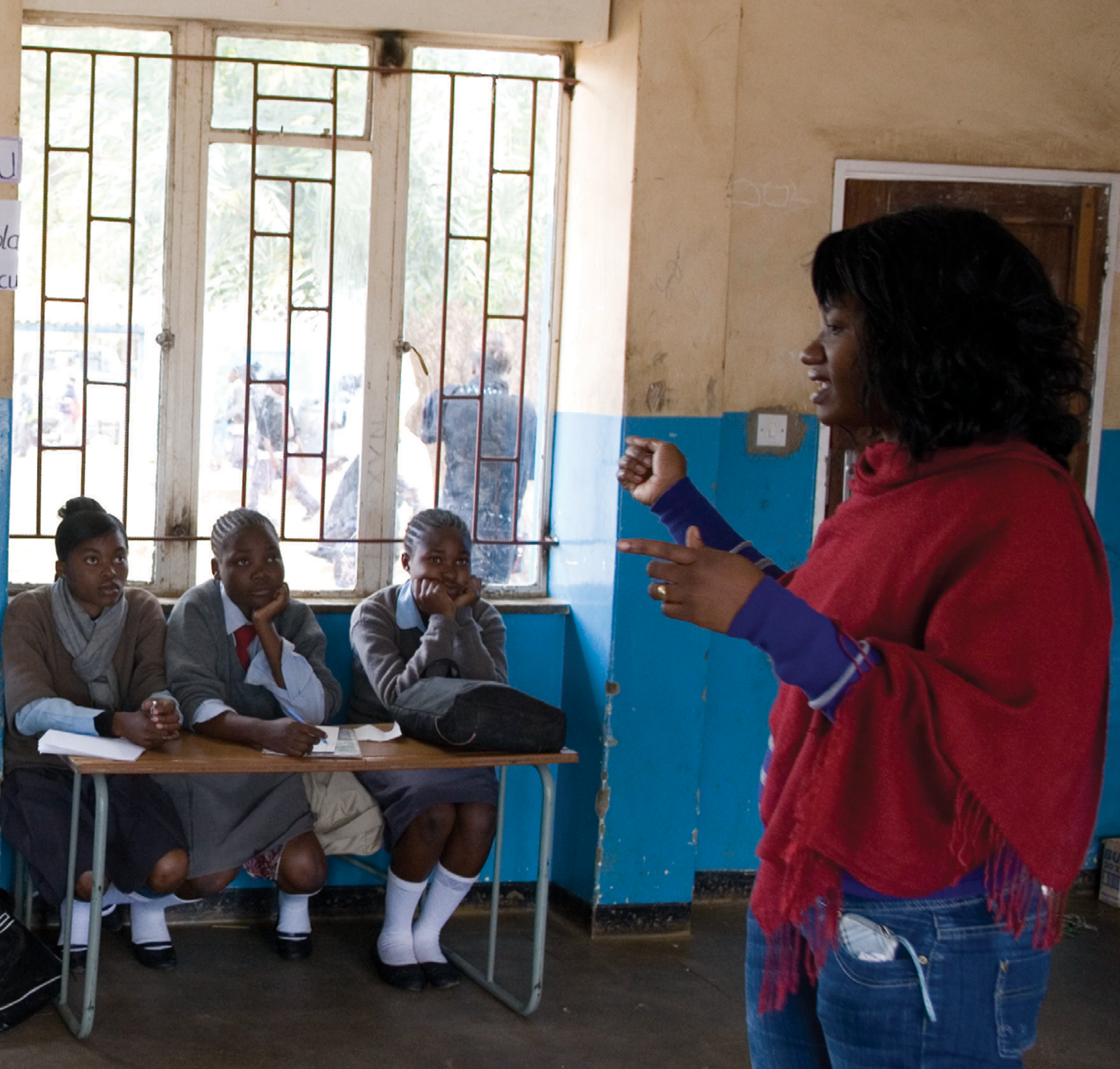


Mentors will usually be the main point of contact between program staff and girls, their families, and the community. Mentors can be vital when they fill critical needs girls have for social support and positive role models. Mentors have a multidimensional role that is new for many programs, and they require training and support.

This section describes the qualities of a good mentor; key mentor responsibilities; how to find and select mentors; and mentor pay.

\section{THE MENTOR MODEL}

The mentor model described in this toolkit differs in important ways from widely used peer educator and teacher-led models. In most programs, mentors' primary responsibility is to deliver the core content of the program; a secondary role may be to serve as a role model and community resource for girls. Mentors also may serve as an intermediary between the girls in a program and resources in a community, helping connect the girls to community resources. Mentors often play a role in helping mediate conflict with parents, employers, or other gatekeepers.

In the mentor model, mentors are females who are slightly older than girls in the program (e.g., a 20-year-old mentor works with a group of 10-14-year-old girls), while peer educators are generally the same age as the girls.

Peer-education programs tend to elevate outstanding members of the group to a leadership position. In contrast, the mentor model gives disadvantaged but promising older girls or young women an opportunity to lead. ${ }^{2}$

Teacher-led programs also differ. Teachers are often much older, sometimes have higher socioeconomic status or come from distant communities, and have a position of authority over girls rather than a relationship that fosters trust and sharing of private and sensitive information. Teachers may relay information to girls as if they are in a classroom rather than fostering participation through interactive methods recommended in girl groups.

\section{What qualities make a good mentor?}

\section{Choosing the right mentors is key to successful program} implementation. Experience indicates that a critical mentor characteristic is that they are local, coming from and living in the community they serve. Why is this important?

- Being local should increase mentors' ability to understand and respond to challenges girls face and enable girls to identify with them.

- Being in the community makes it more likely that parents and guardians will trust mentors and allow girls to participate, and ensures mentors are accessible to girls if they need them outside of regular meeting times.

2 https://knowledgecommons.popcouncil.org/departments_sbsr-pgy/583/ 
- Recruiting locally is an investment in female leadership, enabling local older girls and young women with leadership potential to gain and exercise skills that would otherwise be neglected.

- It may challenge community norms about what girls and young women can do, providing positive alternative role models for girls in a community and eventually giving girls and young women more "voice" in household and community decision-making. ${ }^{3}$

Recruiting mentors locally may also come with challenges. For example, as products of the same social environment, mentors may uphold some of the same ideas and norms a program hopes to tackle, particularly around sensitive issues such as sexual and reproductive health ( $\mathrm{SRH}$ ) and gender inequality. Open communication, training, and discussing the guiding values for the program are critical steps to equip mentors to deliver the messages a program wants to impart. Additionally, local mentors can help deliver these messages in a way that will be culturally acceptable.

\section{What are ideal mentor characteristics?}

\section{The profile of the mentor should correspond to girls who are in the program-in other words,} mentors should be young enough and similar enough to the girls they are working with to be relatable, yet old enough to be role models. It is best if mentors are not only from the same community as the girls in the program, but also representative of the segment of girls in the program. For example, if married girls are the main participants, mentors also should be married; migrant girls should be paired with a migrant mentor. In the same way that girls benefit from being in groups with girls like them, they also thrive when they can relate to their mentor.
- Mentors should be people the girls feel they can learn from. Most mentors in programs described in this toolkit are between 18 and 30 years of age, and meet education and literacy requirements like having finished a certain amount of schooling (usually at least a few years of secondary school). Most programs require that mentors can read, write, and communicate effectively in the local language.

- Program participants may have their own ideas about what makes a good mentor. For example, participants in a program in Burkina Faso suggested that the most important characteristics of a good mentor are to be discreet, trustworthy, attentive, polite, and welcoming. ${ }^{4}$

- These criteria are flexible; each program must adapt to the local situation. For example, programs may need to use mentors who don't "match" the girls if not enough mentors can be found who meet the original criteria. Mentors do not have to start out as ideal candidates-it can be beneficial to train promising young women who have not yet had the opportunity to lead. In recruiting mentors, you can extend a chance to thrive to young people who have otherwise been overlooked but have a desire to work with girls. Mentors should not just be drawn from the pool of high achievers who typically participate as leaders. 


\section{MENTOR SELECTION CRITERIA}

The following is a sample list of qualifications that can be used as criteria for selecting mentors; the list also specifies what is needed to be a teacher or a community mentor, whose roles differed in the program that originated this tool. The tool also lists the steps for selecting mentors.

\section{Qualifications/requirements for both teacher and} community mentors

- Literate/can read and write

- Respected in the community, serving as a role model to young women

- Possesses leadership qualities

- Experience working with the community and vulnerable groups

- Experience with training and/or facilitation of groups

- Basic knowledge of sexual and reproductive health preferred

- Willing and flexible to attend to girls' concerns outside the safe space hours

- Committed to improving the situation of girls in her community

- Fluent in English and the local language(s) of the community

- Experience using technology such as smart phones or tablets an added advantage

\section{Criteria for teacher mentors}

- Female teacher at program school-but not Grade 7 teacher

- Must have completed Grade 12 and have teaching certification

\section{Criteria for community mentors}

- Female volunteer between the ages of 20 and 40 residing in the same community as the school (or close by)

- Must have completed Grade 12

\section{Steps for selecting mentors}

- Short-list mentors: 3 individuals per category

- Develop interview schedule with local partner

- Call candidates for interviews

- Conduct interviews by panel from school (if school-based) or community (if communitybased): 2-3 members and local partner

- Select candidate

- Inform relevant local partner

- Invite for training (letter will be provided by local partner) 


\section{MENTOR RECRUITMENT}

Once a program has identified the types of mentors needed, how can a program team find them?

Even the most distressed communities will usually have a few young women who have completed some secondary school and have the potential to be a good mentor.

The best approach to find mentor candidates depends on the context and where people go to learn about new opportunities. For example, the Filles Eveillées program in Burkina Faso used a public announcer to broadcast information about mentor positions using a loudspeaker mounted on a car that drove around relevant communities. Interested candidates with the appropriate qualifications were invited to submit applications and resumes. ${ }^{5}$

Other methods used to identify mentors include:

- Radio announcements or posters with the announcement in prominent places around the community like clinics, schools, and council offices, or distributed during community events.

- Sharing the job description with key community leaders. ${ }^{6}$

- Peer referrals or recruiting using recommendations from the girls themselves.

- A Population Council tool called the Girl Roster $^{\mathrm{TM}} 7$ that collects community-level population information can help identify potential mentors (see Box).

- After a program is running in a community, former participants may graduate into a mentor role, an approach called "cascading leadership."

\section{The Population Council's Girl Roster ${ }^{\mathrm{TM}}$}

The Population Council's Girl Roster ${ }^{\mathrm{TM}}$ tool was developed to equip program staff to gather and use information about program communities. The Roster is conducted in three steps:

1. Program staff visit every household in a set geographic area to conduct a brief survey with an adult to collect basic information on all girls in the household.

2. Survey results are compiled and automatically sorted to produce a visual snapshot of the total number of girlsorganized by important characteristics such as age and schooling status.

3. Staff use these snapshots to plan their programs, beginning with the question of which girls to recruit and what strategies they will use to recruit them.

5 https://knowledgecommons.popcouncil.org/departments_sbsr-pgy/581/

6 https://knowledgecommons.popcouncil.org/departments_sbsr-pgy/553/

7 https://knowledgecommons.popcouncil.org/departments_sbsr-pgy/468/ 


\section{MENTOR ADVERTISEMENT}

The mentor advertisement

should include a brief program description, job description and qualifications, and procedure for applying. ${ }^{8}$ The job description is helpful for reminding the mentor what her responsibilities are, and also setting boundaries for what the expectations of the job are. This advertisement should be customized with the logos of partners, with relevant information added to the blank spaces as specified.

\section{Advertisement}

Female Mentors Wanted!

[Name of program]

[Name of partner 1]

[Name of partner 2] and partners seek to recruit

female volunteers between the ages of and to work as mentors for

[Name of program] over a period of years.

The program will implement a social, health, and economic asset-building program for vulnerable adolescent girls in [Country]

Girls will join a group of about $\underline{\text { [Number: 25-30] }}$ girls that meets $\underline{\text { [Frequency, usually } 1 \mathrm{X} \text { per week] }}$ in their community, under the guidance of a female mentor. During their group meetings, girls will be trained on:

[Program description. For example: health and financial education; building relationships with girls in the community]

Mentors are sought to facilitate the girls' groups.

Applications must include: Name, age, residence/location, education, relevant work experience, phone number.

The deadline for receiving applications is: [Date]

Applications should be addressed to:

Mentor Application

[Program name]

[Address]

8 https://knowledgecommons.popcouncil.org/departments_sbsr-pgy/552/ 


\section{Job Description}

- Attend initial mentor training of trainers (ToT).

- Recruit girls into the program according to predetermined guidelines. This will include recruiting girls from certain ages and characteristics.

- Prepare for and facilitate weekly group meetings.

- Each mentor will be responsible for [Number] groups, each with $\underline{\text { [Number] }}$ girls. The group meetings are to be engaging, interactive, and dynamic. Mentors will have a core set of training content to cover.

- Training will include sessions on, at a minimum:

[Core package. For example: financial education; sexual and reproductive health; life skills; gender-based violence.]

- Identify an appropriate meeting place and time for each group meeting, including alternate venues for [Community considerations. For example: the rainy season. ]

- Organize meetings with parents, spouses, and community members as appropriate, to be done in conjunction with staff from [Name of partner]

- Conduct home visits when girls miss more than two consecutive meetings.

- Attend [Frequency] mentor meetings/refresher trainings.

- Complete weekly and monthly group activity reporting forms.

- It is anticipated that the mentor will be required to spend [Number. For example: 30-40 hours/month.] of her time.

\section{Qualifications and Requirements}

- Female between the ages of and residing in the same community as the girls in her group

- Literate

- Respected in the community, serving as a role model to young women

- Possesses leadership qualities

- Experience working with the community and vulnerable groups

- Experience with training and/or facilitation of groups

- Basic knowledge of sexual and reproductive health preferred

- Willing to carry out duties listed above

- Willing and flexible to attend to girls' concerns outside the Safe Space hours

- Committed to improving the situation of girls in her community

- Fluent in the official language and the language(s) of the community 


\section{ADOLESCENT GIRLS EMPOWERMENT PROGRAM: MENTOR RECRUITMENT}

The Adolescent Girls Empowerment Program (AGEP) was conducted over two years to support more than 11,000 vulnerable adolescent girls aged 10-19 years in rural and urban Zambia. As facilitators of all the training for girls, it was important that AGEP mentors had the education, skills, and commitment to run weekly group meetings.

In an attempt to find the best candidates, the program team developed a mentor job description and shared it with key community leaders as well as posting it in public spaces such as clinics, schools, and government offices in the program sites. To apply, interested candidates wrote a cover letter with personal details, work experience, and reasons for their interest in the position. When available, they attached their curriculum vitae.

After receiving applications, the program team shortlisted mentor candidates and conducted professional interviews to assess knowledge, skills, background, motivation to work with girls, and personal values around girls' accessing sexual and reproductive health information and services. After scoring the interviews, the top 35 candidates at each site received an invitation to attend an eight-day residential training of trainers (ToT).

During the ToT, the program team observed candidates in action and evaluated their performance on the critical selection criteria. After the ToT, about 70 percent of the candidates were confirmed as AGEP mentors, 15 percent were selected as alternate mentors (in case confirmed mentors dropped out), and 15 percent were not confirmed. This vetting process helped screen for mentors who performed well "on paper" or in the interview but stumbled in practice at the training. Once confirmed and running weekly meetings, mentors continued to receive training and technical support through monthly mentor meetings and a one-time five-day refresher training.

AGEP administered a mentor quality assessment that showed that girls in groups with mentors who had more progressive attitudes about adolescent sexuality and contraceptive use were less likely to be pregnant. This reemphasizes the importance of conducting a careful assessment of mentor values as part of the recruitment process.

For more information: Adolescent Girls Empowerment Programme: Research and Evaluation Mid-Term Technical Report. 2016. https://knowledgecommons.popcouncil.org/departments_ sbsr-pgy/553/ 


\section{RECRUITMENT: INTERVIEW AND SELECTION}

When it comes to mentor recruitment, it is good practice to interview and train more mentors than the program needs; some mentors may not meet performance expectations during the training, and others may drop out mid-program or be unable to carry out their duties. Also, more mentors will be needed if the program grows. ${ }^{9}$

While it is important to have a mentor job description that lays out what a mentor is expected to do, mentors may do even more than is expected of them. The mentor interview is a good opportunity to set expectations for the work. In addition, some programs have mentors rewrite their job description after several months to better reflect their duties.

A contract outlining the organization's expectations for the mentor can also be useful for both the mentor and program staff to hold the mentor accountable for what she has signed on to do. Having a document both the mentor and the program can reference in case of any problems (mentor underperformance or the addition of new duties) is important, particularly since this may be the first experience with formal community work for most mentors.

Mentors should be evaluated using a set of objective criteria, not just whether they seem likable and want the job (though those are important factors too).

\section{Mentor candidate interview questions}

1. Why are you interested in becoming a mentor for our program?

2. How old are you?

3. Where do you live? And how long have you lived there?

4. What grade did you complete and from where/ what school? And do you have any additional training and/or qualifications?

5. Have you done community work before? If so, what, where, and when?

6. Do you have experience working with adolescent girls or any other vulnerable groups in the community?

7. Do you have experience facilitating any kind of life skills, gender, and sexual and reproductive health (SRH) lessons in schools or the community? If so, what, where, and when?

8. What are some of the $\mathrm{SRH}$ issues that girls aged 10-17 years should not know about? Ask for reasons for anything mentioned.

9. When should adolescent girls start learning about SRH? Ask for reasons.

10. Are you currently committed to other work/ programs?

11. What would you do if a girl in your safe space group comes to you and tells you that she is pregnant and cannot continue with her education?

12. What do you think should be done to encourage girls to stay longer in school and to complete their education? 


\section{RECRUITMENT: INTERVIEW AND SELECTION (continued)}

13. What would you do if a girl in your safe space group does not attend the group meetings for two weeks in a row?

14. How would you rate your skills using technology such as smart phones or tablets? (Rate from 0 to 3 ) $\mathrm{O}=$ no experience, $1=$ little experience, $2=$ being fairly experienced, $3=$ being very experienced. (This question will not be relevant for most programs)

\begin{tabular}{|l|l|l|l|l|}
\hline & 0 & 1 & 2 & 3 \\
\hline RATING & & & & \\
\hline
\end{tabular}

15. What is your current availability for this position? How many hours per week would you be able to commit to the mentor position knowing that meetings will take place in the (morning/afternoon/ evening) on (days of the week)?

16. Are you available to attend a (number of days) training in (location and date)?

17. Do you have any questions about the program? 


\section{MENTOR INTERVIEW SCORE SHEET}

This score sheet may be used during a mentor interview and uses points for a range of criteria including appropriate age and location, level of education, and experience. Criteria that are important in the program context may be added. For example, a program that expects mentors to report attendance or other information via mobile phones may want mentors to be familiar with mobile phone use.

Name of candidate

Name of interviewer

Date of interview

\begin{tabular}{|c|c|c|c|}
\hline Criteria & Points & Score & Comments \\
\hline $\begin{array}{l}\text { Appropriate age and location:__to__years } \\
\text { old; lives in the community }\end{array}$ & 20 & & \\
\hline $\begin{array}{l}\text { Education and communication: Education } \\
\text { level completed; ability to communicate in } \\
\text { English and/or relevant local language; years } \\
\text { of relevant experience }\end{array}$ & 20 & & \\
\hline $\begin{array}{l}\text { Knowledge of work: Experience doing } \\
\text { community work; experience facilitating } \\
\text { lessons whether in the community or in the } \\
\text { classroom }\end{array}$ & 10 & & \\
\hline $\begin{array}{l}\text { Knowledge of life skills and sexual and } \\
\text { reproductive health (SRH); Experience } \\
\text { working with adolescent girls and } \\
\text { vulnerable groups }\end{array}$ & 10 & & \\
\hline $\begin{array}{l}\text { Values on sexual health: Level of comfort } \\
\text { when talking about SRH and girls accessing } \\
\text { SRH services }\end{array}$ & 20 & & \\
\hline $\begin{array}{l}\text { Adaptability and social outlook: Consider } \\
\text { maturity of views re: scenarios presented, } \\
\text { ability to work independently, flexibility in } \\
\text { outlook }\end{array}$ & 10 & & \\
\hline $\begin{array}{l}\text { Personality: Consider mental alertness, first } \\
\text { impression, mannerisms, and behavior }\end{array}$ & 5 & & \\
\hline $\begin{array}{l}\text { Give the candidate a paragraph to read } \\
\text { aloud }\end{array}$ & 5 & & \\
\hline TOTAL POINTS & 100 & & \\
\hline
\end{tabular}

The candidate is: $\square$ suitable $\square$ unsuitable

General comments:

Name of the interviewer

Signature Date 


\section{MENTOR SERVICE CONTRACT}

The service contract formalizes the agreement a program has with each mentor, based on the job description advertised. A contract should include details on pay, working hours, duties, and penalties for breaking specific rules.

Work agreement between:_[Lead organization]

and [Program name]

for [Program name]

\section{BACKGROUND}

The [Lead organization]

in partnership with_[Partner organization]

through funding from [Partner organization] will be implementing a [Duration] program in [Number and names of communities] The funds will enable

[Organization name]

to engage [Program name]

Mentors will be based in communities to spearhead implementation of program activities. The Program Mentors will report to the $[$ [Title/Name of mentor] based in their respective communities.

\section{SERVICE CONTRACT DETAILS}

Engagement Duration: This Service Agreement is entered between the mentor and [Lead organization] and the Mentor during [Exact dates or program start and end]

Monthly Allowance: The Mentor will be paid a [Frequency; e.g., monthly] allowance of [Stipend amount] for the duration of the contract to cover transport, communication, and lunch costs. The allowance will only be paid upon the facilitation of [Frequency; e.g., weekly] safe space groups and completion of [Frequency; e.g., monthly] activity reports and safe space participant attendance registers.

Working Hours: The Mentor will be expected to work up to [Number] hours each month over a period of [Number] years. This will include running weekly safe space groups for [Duration of each meeting] each and some additional time for home visits, attending a [Frequency; e.g., monthly] mentor meeting and other supportive activities.

Reporting: The Mentor will report to the Supervisor based in the community. If for any reason, the Mentor is unable to carry out duties, the Mentor is required to inform the Supervisor.

Termination of Contract: Either party can terminate the contract by giving onemonth notice. In the event that either party fails to meet the stipulated terms in this agreement without valid justification, the agreement can be terminated without notice. 


\section{SPECIFIC FUNCTIONS}

The Mentor will perform the following functions:

- Recruit girls' into the program according to predetermined guidelines and in close collaboration with the Supervisor.

- Prepare for and facilitate group meetings (frequency indicated on this contract).

- Manage [Number] of safe space meetings per week made up of about [Number; e.g., 10-15] girls each.

- Facilitate interactive and dynamic group meetings in safe spaces.

- Ensure timely and complete coverage of set curriculum for safe spaces which will include sessions on [e.g., Education benefits, financial education, sexual and reproductive health, life skills, gender and gender-based violence]

- Secure and maintain a meeting location in consultation with the Supervisor.

- Organize community meetings with the girls' parents and other community members in collaboration with the Supervisor.

- Conduct home visits when girls miss more than two consecutive meetings in collaboration with the Supervisor.

- Attend [Frequency] mentor meetings run by the Supervisor.

- Attend refresher training as may be invited by the Supervisor.

- Complete [Frequency; e.g., weekly or monthly] group activity reporting forms.

- Update attendance data on a [Frequency; e.g., weekly] basis.

- Take custody of the program assets and documents supplied by the program.

- Undertake other program duties as may be assigned by the Supervisor.

\section{MENTOR PENALTIES}

The following penalties will apply if any of the rules are broken by the mentor:

- If a mentor misses her safe space meeting without permission or making prior arrangements with a fellow mentor to cover the meeting for her during her absence, [Amount of money] _ will be deducted from the mentors' stipend for each meeting missed. Regular performance evaluation will be conducted each quarter by [Lead organization]

- In the event that the mentor is caught falsifying her attendance records or lying about conducting program activities, she will be suspended along with her stipend until a review is conducted.

\section{OBLIGATIONS}

In this agreement [Organization name]

an all-inclusive [Frequency; e.g., monthly] will be limited to pay, through the [Mechanism, e.g., bank account] stipend of [Amount] only.

Signed on behalf of [Organization name]

Executive Director:

Date:

Program Mentor:

Date:

Witness:

Date: 


\section{MENTOR COMPENSATION}

Mentors are not volunteers and their important hard work should be compensated appropriately. Paying mentors makes it more likely they will be dedicated to the program and do quality work. It also serves as a demonstration that the work they are doing is valuable and creates a livelihood opportunity for young women in the community. Conversely, trying to save money by not paying mentors can lead to higher turnover and increase training costs, reducing the sustainability of the program. Failing to pay mentors suggests their work is not valuable nor valued. ${ }^{10,11,12}$

Wages vary across programs depending on the location and the expectations of mentors (in terms of time commitment and duties); however, programs should always pay mentors a similar amount to wages in the community for comparable work, such as government extension or community health workers. The range of stipends that Population Council programs have given in recent years is between $\$ 40$ to $\$ 150$ USD monthly for up to 40 hours of work. Across programs surveyed as part of the preparation for this toolkit, mentors within a particular program were paid similar amounts, though in some settings they received bonuses for leading additional groups. Some programs provide additional compensation, such as bicycles, payment for transport, lunch, rain boots and raincoats, holiday bonuses, phone credit and internet bundles for phones, and salary raises for each year as a mentor (e.g., a 5-10 percent increase).
Payment linked to fulfilling the responsibilities laid out in the mentor's contract is important, but detailed contracts can also cause complaints by mentors when they are asked to do tasks that fall outside their regular responsibilities. Finding a balance between having clear expectations for mentors' responsibilities while not overly constraining what small additional tasks may help them complete their work but not require more pay can be a challenge that is worth addressing in advance. Some programs include provisions to reduce mentors' pay if they miss sessions or falsify records, though in practice this is hard to enforce. ${ }^{13}$

Mentors also value nonfinancial benefits, such as certificates after completing mentor training, the experience of mentoring, acquiring new skills, and recognition or awards for exceptional commitment or performance. For example, the Abriendo Oportunidades program in Guatemala offers mentors the opportunity to participate in special training on topics of interest, such as human rights and social research. ${ }^{14}$ The social status of being a mentor in the community can also be an incentive for mentors.

Methods of mentor payment take various forms. Most programs require mentors to open bank accounts-the first one for many mentors-and deposit monthly stipends after they turn in their monthly reports. Programs may also want to consider mobile-phone-based money transfers to pay mentors where they are available. Cash payments are discouraged because they can put mentors at risk of theft.

\footnotetext{
10 https://knowledgecommons.popcouncil.org/departments_sbsr-pgy/578/

11 https://knowledgecommons.popcouncil.org/departments_sbsr-pgy/583/

12 https://knowledgecommons.popcouncil.org/departments_sbsr-pgy/579/

$13 \mathrm{https}$ ://knowledgecommons.popcouncil.org/departments_sbsr-pgy/552/

${ }^{14}$ https://youtu.be/thexSWHguA
} 
CHAPTER 2

Mentor training and retention

CASE STUDY

GUIDE

TOOL

TOOL

TOOL

TOOL

ACTIVITY

ACTIVITY

ACTIVITY

ACTIVITY

ACTIVITY

ACTIVITY

ACTIVITY

ACTIVITY

TOOL

ACTIVITY

ACTIVITY

CASE STUDY
GirlsRead!: Mentor Training and Monthly Meetings

Page 27

Nuts and Bolts of Training

Initial Training-of-Trainers Agenda

29

Training-of-Trainers Agenda: Facilitating Groups and Community Engagement

Daily Evaluation Form

Monthly Mentor Meeting Agenda

Training Presentation: What Is a Mentor?

Training Presentation: Basic Facilitation Skills

50

Facilitation Skills

54

Training Methodologies

56

The Mentor's Role in Teaching and Learning 60

Training Presentation: Introduction to Counseling

62

Mentor Training Session on Gender-based Violence and Human Rights 65

Mentor Training Session on Working with Girls with Disabilities

68

Refresher Training-of-Trainers Agenda

69

Mentor Refresher Training

74

Candle-Lighting Ceremony: Conclusion of Mentor Training

75

BALIKA: Enhancing Mentor Capacity with Weekly Mock

Demonstration Sessions 


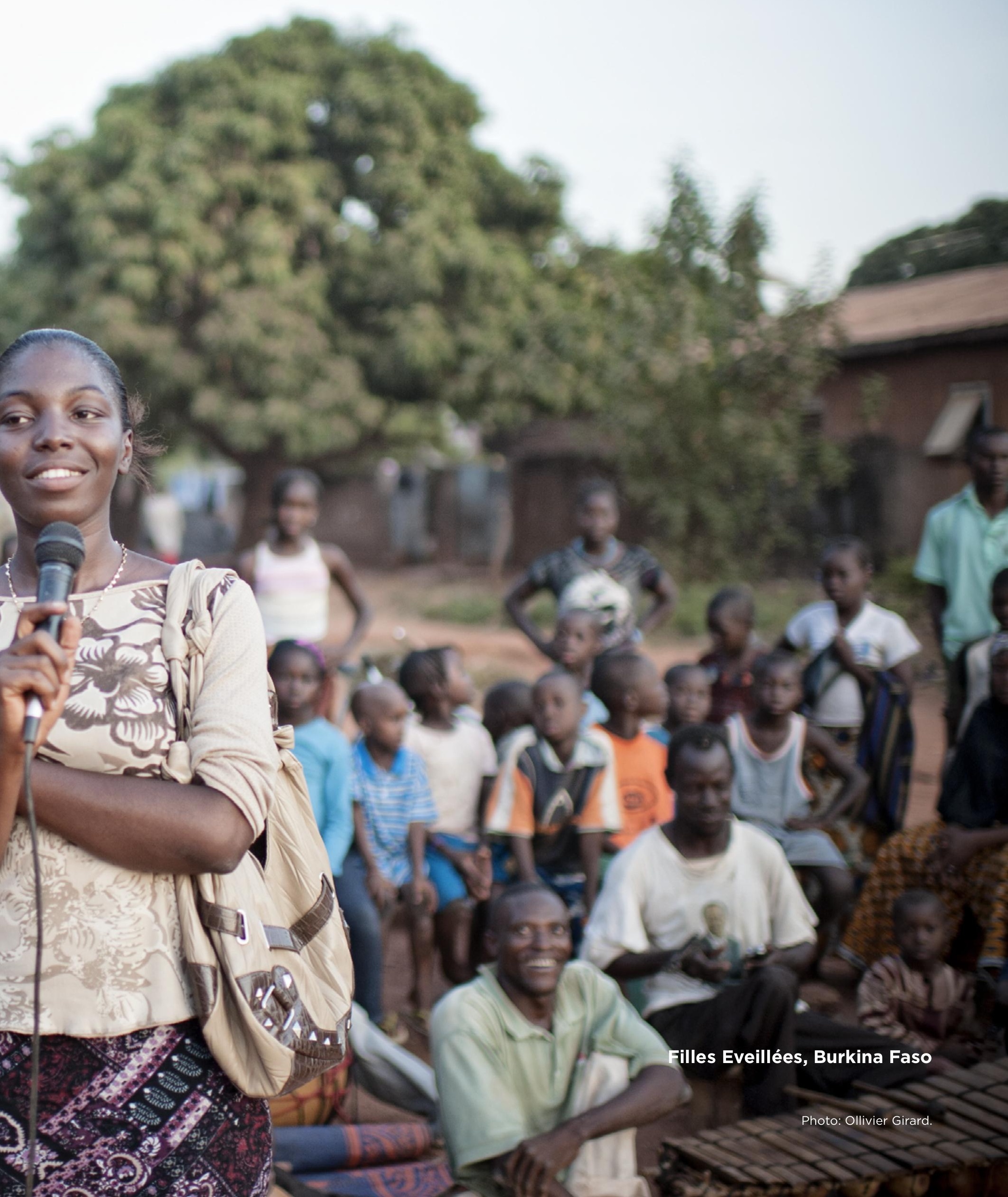


Adequately training-and retraining-mentors to fulfill their roles is vital for a successful program. Mentors receive training in curricula they will deliver, as well as how to function as a mentor. Mentors need to be comfortable with the program material and practice new teaching and facilitation techniques. Many mentors-in-training are expected to teach material that is unfamiliar to them; their training is an opportunity to impart key values, particularly around sensitive subjects like sexual and reproductive health.

Training is not a one-time event; mentors need ongoing support, coaching, and opportunities for continuous learning. Most programs provide refresher trainings as the program progresses, and some have weekly or monthly meetings with program staff so mentors can ask questions, share experiences, gain support, and practice new skills.

Mentors can help each other thrive when they have a space to share challenges and successes on a regular basis. For example, providing opportunities for mentors to get together and practice facilitating sessions with each other builds social capital and helps them motivate, learn from, and support each other. This also helps build their social networks. ${ }^{15}$

The following section provides examples of how Population Council programs have handled training. Included are sample agendas for trainings of different lengths, and presentations and activities used.

15 https://knowledgecommons.popcouncil.org/departments_sbsr-pgy/583/ 


\section{GIRLSREAD!: MENTOR TRAINING AND MONTHLY MEETINGS}

GirlsRead! Zambia tested the use of e-reader technology, girls' groups led by female mentors, and community engagement of parents, school administrators, and community leaders to improve girls' literacy and agency, and through these pathways to contribute to a reduction in HIV risk. The program was implemented with Grade 7 girls in three sites in Zambia at 36 government schools reaching over 2,000 girls over a two-year period. The GirlsRead! program used mentor pairs-a community mentor and a teacher mentor-at each school to lead the weekly safe space meetings.

The training and ongoing support of GirlsRead! mentors was critical to program success. After undergoing a rigorous recruitment process, the selected candidates attended a six-day residential training of trainers (TOT) where they learned about the program design and rationale; their role as GirlsRead! mentors; the empowerment curricula topics; nonformal, interactive facilitation techniques; values clarification exercises related to girls' rights to access sexual and reproductive health (SRH) information and services; and how to use the e-reader and facilitate e-reader curriculum sessions.

The training focused on building GirlsRead! mentors' technical capacity to facilitate weekly sessions effectively-addressing both the empowerment and e-reader components of the program-while also teaching mentors tools and techniques to build trusting relationships with the girls, parents, community members, and school administrators. Practical sessions were central to the training as well, with mentors facilitating the GirlsRead! curricula in front of peers and the program team, followed by a constructive feedback session. The ToT experience created the foundation of a safe and supportive environment for the mentors to learn and grow over the duration of the program.

After the ToT, mentors returned to their communities and started running weekly GirlsRead! sessions. At the end of each month, mentors came together with the program team at the district level to share updates from the previous month including successes, challenges, and proposed solutions. Mentors also submitted activity reports and received monthly stipends at this time, motivating regular participation. Beyond the program management and administrative components, these meetings allowed mentors to receive: ongoing technical assistance and training on critical topics from the empowerment curriculum; tips on how to troubleshoot problems with e-readers and the electronic data attendance application; and guidance on how to handle referrals and report emerging gender-based violence (GBV) or SRH issues. The monthly mentor meetings expanded mentors' knowledge and skills, provided technical and emotional support, and enhanced the monitoring of mentors' performance beyond the initial TOT and regular monitoring visits from program staff.

For more information: GirlsRead! Zambia: DREAMS Innovation Challenge. 2018. Brief. https://knowledgecommons.popcouncil. org/departments_sbsr-pgy/614/ 


\section{NUTS AND BOLTS OF TRAINING}

Early in a program, an initial mentor training is typically conducted. This training can last from four days to two weeks, and usually includes the curriculum to be delivered, topics including group management skills, and discussion of mentor responsibilities such as home visits or community meetings.

Programs that require mentors to use tools such as mobile phones or tablets also train mentors in these skills at this time. Mentors for BALIKA (Bangladeshi Association for Life Skills, Income, and Knowledge for Adolescents) ${ }^{16}$, for example, received training in mobile phone servicing, photography, and basic first aid. Trainings should be interactive and provide opportunities for mentors to role-play and practice the skills they will use in the program.

The appropriate length of the initial training will be determined by the amount and type of material mentors are expected to master, and the mentors' level of familiarity with the content and approaches. For example, the BALIKA program included four days of training on basic life skills and three days on gender issues. ${ }^{17,18}$
In the Filles Eveillées program in Burkina Faso, training initially lasted three days. When mentors requested more time for an in-depth discussion of the curriculum and facilitation techniques, trainings were extended to four days. ${ }^{19}$

Opportunities for mentors to learn and practice their skills often follow an initial training. These opportunities usually take place during refresher trainings held two to three months after a program starts, and during weekly or monthly meetings with site coordinators. During these monthly or weekly meetings, mentors submit their attendance data, discuss successes and challenges, and have brief trainings relevant to upcoming sessions. ${ }^{20}$

A preset agenda can help program staff structure a mentor training.

16 https://www.popcouncil.org/balika

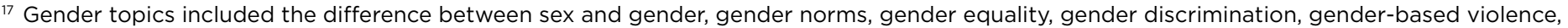
and the consequences of child marriage.

18 https://knowledgecommons.popcouncil.org/departments_sbsr-pgy/557/

${ }^{19}$ https://knowledgecommons.popcouncil.org/departments_sbsr-pgy/581/

${ }^{20}$ https://knowledgecommons.popcouncil.org/departments_sbsr-pgy/552/ 


\section{INITIAL TRAINING-OF-TRAINERS AGENDA}

This tool provides a sample agenda from an initial 8.5-day training with 35 mentor participants. This is an example of training for a curriculum that is school-based and includes health and financial education. Workshop objectives were to understand the program concepts; gain accurate information on life skills, sexual and reproductive health, and financial management; acquire facilitation skills using interactive methods; and build confidence in offering guidance and social support to girls during safe space meetings.

[Program name] Roll out mentors' initial training-of-trainers agenda

Training Period: 8.5 days

Date: Site:

Participants:

Venue: Facilitators:

Objectives:

The overall objective of the training-of-trainers workshop is to build mentors' capacity to facilitate the implementation of safe spaces and effectively deliver health, life-skills, and financial-education curricula to the girls in the program.

The specific objectives of the workshop are to enable participants to:

- Acquire comprehensive understanding of the concepts of the program.

- Acquire accurate information on life skills, sexual and reproductive health, and financial management.

- Acquire the skills to facilitate a range of interactive methodologies to be used during the safe space sessions.

- Acquire the skills to offer guidance and social support to girls during safe spaces meetings.

\section{Expected outcome:}

Confident, competent safe space mentors with skills to implement safe space activities and deliver health, life-skills, and financial-education curricula. 


\section{INITIAL TOT AGENDA (continued)}

Day 1

\begin{tabular}{|c|c|c|c|}
\hline Time & Session & Objectives & Facilitator \\
\hline $16.00-16.15$ & $\begin{array}{l}\text { Welcome, Participant } \\
\text { introductions/ } \\
\text { icebreaker }\end{array}$ & & \\
\hline $16.15-16.45$ & Pretest questionnaire & $\begin{array}{l}\text { - To obtain a baseline level of participants' knowledge, atti- } \\
\text { tudes, and skills regarding the issues to be } \\
\text { covered in the training }\end{array}$ & \\
\hline $16.45-17.00$ & Objectives & - To clarify workshop objectives & \\
\hline $17.00-17.15$ & Ground rules & - To agree on the ground rules for the workshop & \\
\hline $17.15-17.30$ & $\begin{array}{l}\text { Participant expecta- } \\
\text { tions }\end{array}$ & - To share expectations for the training & \\
\hline $17.30-18.30$ & Program overview & $\begin{array}{l}\text { - To familiarize mentors with the program and explain the } \\
\text { program objectives }\end{array}$ & \\
\hline
\end{tabular}

Day 2

\begin{tabular}{|c|c|c|c|}
\hline Time & Session & Objectives & Facilitator \\
\hline $8.00-8.15$ & $\begin{array}{l}\text { Energizer/ } \\
\text { Housekeeping }\end{array}$ & $\begin{array}{l}\text { - To provide participants with the experience of the energizers } \\
\text { from the Energizer Manual/other suggested energizers }\end{array}$ & \\
\hline $8.15-8.30$ & Feedback on Day 1 & - To provide an ongoing evaluation of the workshop & \\
\hline $8.30-10.30$ & $\begin{array}{l}\text { Information Session } \\
\text { What Is a Mentor? }\end{array}$ & $\begin{array}{l}\text { To help participants understand the qualities of a mentor and } \\
\text { the importance of being a role model } \\
\text { To discuss the difference between a mentor and peer } \\
\text { educator } \\
\text { To look over the mentor job description and emphasize the } \\
\text { role of mentors }\end{array}$ & \\
\hline $10.30-11.00$ & \multicolumn{2}{|r|}{ TEA BREAK } & \\
\hline $11.00-13.00$ & $\begin{array}{l}\text { "Why Girls } \\
\text { Programming?"- } \\
\text { Asset-Building } \\
\text { Approach }\end{array}$ & $\begin{array}{l}\text { - To introduce a framework of thinking about programs as } \\
\text { building assets (opportunities and skills) for girls }\end{array}$ & \\
\hline $13.00-14.00$ & \multicolumn{2}{|r|}{ Lunch Break } & \\
\hline $14.00-14.30$ & $\begin{array}{l}\text { Introduction to } \\
\text { training methodology }\end{array}$ & $\begin{array}{l}\text { - To familiarize mentors with the tools to be used during the } \\
\text { program (both curricula) } \\
\text { - A step-by-step guide to using the Health and Life skills } \\
\text { curriculum } \\
\text { - A step-by-step guide to using the Financial Education } \\
\text { curriculum } \\
\text { - Emphasis on using an integrated approach for the two } \\
\text { curricula for all safe-spaces programs }\end{array}$ & \\
\hline $14.30-16.00$ & $\begin{array}{l}\text { Information Session } \\
\text { Facilitation Skills }\end{array}$ & $\begin{array}{l}\text { - } \quad \text { Participants learn different types of facilitation skills } \\
\text { - } \quad \text { Participants understand how to apply these skills during } \\
\text { safe-space sessions } \\
\text { - } \quad \text { Participants practice delivering sessions using different skills }\end{array}$ & \\
\hline $16.00-16.30$ & \multicolumn{2}{|r|}{ TEA BREAK } & \\
\hline \multirow[t]{2}{*}{$16.30-17.30$} & $\begin{array}{l}\text { Information Session } \\
\text { Reproductive Anatomy } \\
\text { and Physiology }\end{array}$ & - $\quad$ Participants understand body anatomy and physiology & \\
\hline & \multicolumn{2}{|r|}{ WRAP UP } & Team \\
\hline
\end{tabular}


Day 3

\begin{tabular}{|c|c|c|c|}
\hline Time & Session & Objectives & Facilitator \\
\hline $8.00-8.15$ & Energizer/Housekeeping & $\begin{array}{l}\text { To provide participants with the experience of } \\
\text { energizers from the Energizer Manual/other } \\
\text { suggested energizers }\end{array}$ & \\
\hline $8.15-8.30$ & Feedback on Day 2 & - $\quad$ To provide an ongoing evaluation of the workshop & \\
\hline $8.30-10.30$ & $\begin{array}{l}\text { Training Topic } \\
\text { Team Work (Health and } \\
\text { Life-Skills Curriculum } \\
\text { Session) }\end{array}$ & $\begin{array}{l}\text { - To familiarize mentors with sessions in the curriculum } \\
\text { - } \quad \text { To increase awareness of the training topic } \\
\text { - To practice how to apply facilitation skills } \\
\text { facilitation skills applied }\end{array}$ & \\
\hline $10.30-11.00$ & \multicolumn{2}{|r|}{ TEA BREAK } & \\
\hline $11.00-13.00$ & $\begin{array}{l}\text { Introduction to the } \\
\text { "Anchor, Add, Apply, } \\
\text { Away" approach to } \\
\text { curriculum } \\
\text { Assignment Session: } \\
\text { Participants are assigned } \\
\text { topics from the program }\end{array}$ & $\begin{array}{l}\text { - Participants understand the four A's and learn how to } \\
\text { apply them when delivering sessions in the curriculum } \\
\text { Participants are divided into four groups and each } \\
\text { group is designated a session to prepare and present }\end{array}$ & \\
\hline $13.00-14.00$ & \multicolumn{2}{|r|}{ LUNCH } & \\
\hline $14.00-16.00$ & $\begin{array}{l}\text { Training Topic } \\
\text { Self-Esteem (Health and } \\
\text { Life-Skills Curriculum } \\
\text { Session) }\end{array}$ & $\begin{array}{l}\text { - To familiarize mentors with sessions in the curriculum } \\
\text { - } \quad \text { To increase awareness of the training topic } \\
\text { - } \quad \text { To practice how to apply facilitation skills } \\
\text { - } \quad \text { go get feedback from mentors on session delivery and } \\
\text { facilitation skills applied } \\
\text { - Participants identify the } 4 \text { A's in the session }\end{array}$ & \\
\hline $16.00-16.30$ & \multicolumn{2}{|r|}{ TEA BREAK } & \\
\hline $16.30-18.30$ & $\begin{array}{l}\text { Information Session } \\
\text { Growing-Up-Sexuality } \\
\text { Continuum }\end{array}$ & $\begin{array}{l}\text { - To provide participants with comprehensive } \\
\text { information on the physical and emotional changes } \\
\text { experienced at different stages in life } \\
\text { - Participants understand and describe emotional and } \\
\text { physical changes that occur at puberty } \\
\text { - Participants feel more comfortable discussing physical } \\
\text { and emotional changes at puberty }\end{array}$ & \\
\hline & & WRAP UP & \\
\hline
\end{tabular}

Day 4

\begin{tabular}{|c|c|c|c|}
\hline Time & Session & Objectives & Facilitator \\
\hline $8.00-8.15$ & Energizer/Housekeeping & $\begin{array}{l}\text { To provide participants with the experience } \\
\text { of energizers from the Energizer Manual/other } \\
\text { suggested energizers }\end{array}$ & \\
\hline $8.15-8.30$ & Feedback on Day 3 & $\begin{array}{l}\text { - To provide an ongoing evaluation of the } \\
\text { workshop }\end{array}$ & \\
\hline
\end{tabular}




\section{INITIAL TOT AGENDA (continued)}

\begin{tabular}{|c|c|c|}
\hline $8.30-10.30$ & $\begin{array}{l}\text { Practical Session } \\
\text { Participants present } \\
\text { their topics: } \\
\text { - Team 1: Session 4- } \\
\quad \text { Intro Section } \\
\text { Practical session group } \\
\text { feedback }\end{array}$ & $\begin{array}{l}\text { - Participants practice facilitation skills and familiarize } \\
\text { themselves with the safe space curriculum } \\
\text { Participants identify facilitation skills used to } \\
\text { effectively facilitate } \\
\text { Participants discuss challenges encountered during } \\
\text { facilitation }\end{array}$ \\
\hline $10.30-11.00$ & \multicolumn{2}{|r|}{ TEA BREAK } \\
\hline $11.00-13.00$ & $\begin{array}{l}\text { Practical Session } \\
\text { Participants present } \\
\text { their topics: } \\
\text { - Team 2: Session 5- } \\
\quad \text { Intro Section } \\
\text { Practical session group } \\
\text { feedback }\end{array}$ & $\begin{array}{l}\text { - Participants practice facilitation skills and familiarize } \\
\text { themselves with the safe space curriculum } \\
\text { Participants identify facilitation skills used to } \\
\text { effectively facilitate } \\
\text { - Participants discuss challenges encountered during } \\
\text { facilitation }\end{array}$ \\
\hline $13.00-14.00$ & \multicolumn{2}{|r|}{ LUNCH BREAK } \\
\hline $14.00-16.00$ & $\begin{array}{l}\text { Information Session } \\
\text { Basic information on } \\
\text { HIV and AIDS }\end{array}$ & $\begin{array}{l}\text { - Participants understand HIV and AIDS and the } \\
\text { difference between the two } \\
\text { Participants understand modes of transmission of HIV } \\
\text { and social factors contributing to the spread of HIV } \\
\text { such as multiple concurrent partnerships (MCPS) } \\
\text { - Participants understand some of the } \\
\text { preventive measures of HIV }\end{array}$ \\
\hline $16.00-16.30$ & \multicolumn{2}{|r|}{ TEA BREAK } \\
\hline \multirow[t]{2}{*}{$16.30-17.30$} & $\begin{array}{l}\text { Practical Session } \\
\text { Participants present } \\
\text { their topics: } \\
\text { - Team 3: Session 2- } \\
\text { Reproductive } \\
\text { Health } \\
\text { Practical session group } \\
\text { feedback }\end{array}$ & $\begin{array}{l}\text { - Participants practice facilitation skills and familiarize } \\
\text { themselves with the safe space curriculum } \\
\text { Participants identify facilitation skills used to } \\
\text { effectively facilitate } \\
\text { - Participants discuss challenges } \\
\text { encountered during facilitation }\end{array}$ \\
\hline & \multicolumn{2}{|r|}{ WRAP UP } \\
\hline
\end{tabular}

Day 5

\begin{tabular}{|c|c|c|c|}
\hline Time & Session & Objectives & Facilitator \\
\hline $8.00-8.15$ & Energizer/Housekeeping & $\begin{array}{l}\text { - To provide participants with the experience of energizers } \\
\text { from the Energizer Manual/other suggested energizers }\end{array}$ & \\
\hline $8.15-8.30$ & Feedback on Week 1 & To provide an ongoing evaluation of the workshop & \\
\hline $8.30-10.30$ & $\begin{array}{l}\text { Information Session } \\
\text { Effective Communication }\end{array}$ & $\begin{array}{l}\text { - To help participants learn effective communication skills, } \\
\text { including nonverbal communication, verbal encourage- } \\
\text { ment, simple language, and clarification. }\end{array}$ & \\
\hline $10.30-11.00$ & & Tea Break & \\
\hline $11.00-13.00$ & $\begin{array}{l}\text { Practical Session } \\
\text { Participants present their } \\
\text { topic: } \\
\text { - Team 4: Session 1- } \\
\text { HIV/AIDS and STIs } \\
\text { Practical session group } \\
\text { feedback }\end{array}$ & $\begin{array}{l}\text { Participants practice facilitation skills and familiarize } \\
\text { themselves with the safe space curriculum } \\
\text { Participants identify facilitation skills used to effectively } \\
\text { facilitate } \\
\text { - Participants discuss challenges encountered during } \\
\text { facilitation }\end{array}$ & \\
\hline
\end{tabular}




\begin{tabular}{|c|c|c|}
\hline $13.00-14.00$ & \multicolumn{2}{|r|}{ LUNCH } \\
\hline $14.00-16.00$ & $\begin{array}{l}\text { Information Session } \\
\text { Introduction to Counseling }\end{array}$ & - To help participants identify effective counseling skills \\
\hline $16.00-16.30$ & \multicolumn{2}{|r|}{ TEA BREAK } \\
\hline \multirow[t]{2}{*}{$16.30-18.30$} & $\begin{array}{l}\text { Information Session } \\
\text { Conflict Management }\end{array}$ & $\begin{array}{l}\text { - } \quad \text { Participants understand why conflicts arise } \\
\text { - } \quad \text { Eonditions leading to conflicts } \\
\text { - Ways to deal with conflict situations: response styles and } \\
\text { - } \quad \text { Strategies for managing conflicts }\end{array}$ \\
\hline & & WRAP UP \\
\hline
\end{tabular}

\section{Day 6}

\begin{tabular}{|c|c|c|c|}
\hline Time & Session & Objectives & Facilitator \\
\hline $8.00-8.15$ & Energizer/Housekeeping & $\begin{array}{l}\text { - To provide participants with the experience of energizers } \\
\text { from the Energizer Manual/other suggested energizers }\end{array}$ & \\
\hline $8.15-8.30$ & Feedback on Day 5 & - To provide an ongoing evaluation of the workshop & \\
\hline $8.30-10.30$ & $\begin{array}{l}\text { Information Session } \\
\text { Values clarification in } \\
\text { Sexual and Reproductive } \\
\text { Health (SRH) for } \\
\text { adolescent girls }\end{array}$ & $\begin{array}{l}\text { - To address mentors' knowledge, attitudes, and behaviors } \\
\text { regarding SRH for adolescent girls } \\
\text { - To provide an overview of the reality on the ground for } \\
\text { adolescent girls and SRH } \\
\text { - To enhance awareness of adolescent girls' SRH rights in } \\
\text { [Country] }\end{array}$ & \\
\hline $10.30-11.00$ & \multicolumn{2}{|r|}{ TEA BREAK } & \\
\hline $11.00-13.00$ & $\begin{array}{l}\text { Information Session } \\
\text { Contraceptives }\end{array}$ & $\begin{array}{l}\text { - To understand different contraceptive methods } \\
\text { and how they work } \\
\text { - To describe different contraceptive methods } \\
\text { - To clear myths and misconceptions regarding } \\
\text { contraceptive methods }\end{array}$ & \\
\hline $13.00-14.00$ & \multicolumn{2}{|r|}{ LUNCH } & \\
\hline $14.00-16.00$ & $\begin{array}{l}\text { Information Session } \\
\text { Unsafe Abortion }\end{array}$ & $\begin{array}{l}\text { By the end of the session, participants should be able to; } \\
\text { - Define abortion } \\
\text { - } \quad \text { Describe five complications of unsafe abortion } \\
\text { - Understand the laws about abortion in } \\
\text { - } \quad \text { Clarify their values concerning abortion } \\
\text { - Describe how stigma affects individual and societal } \\
\text { views and reactions to abortion }\end{array}$ & \\
\hline \multicolumn{4}{|l|}{$16.00-16.30$} \\
\hline \multirow[t]{2}{*}{$16.30-18.30$} & $\begin{array}{l}\text { Information Session } \\
\text { Working with Parents and } \\
\text { Critical Adults }\end{array}$ & $\begin{array}{l}\text { - Participants identify critical adults in the life of an } \\
\text { adolescent girl } \\
\text { Participants learn different strategies of successfully } \\
\text { engaging the parents and critical adults of the } \\
\text { adolescent girls } \\
\text { - } \quad \text { Participants learn how to communicate with adults } \\
\text { - Participants practice delivering talking points to the } \\
\text { parents and critical adults }\end{array}$ & \\
\hline & \multicolumn{2}{|r|}{ WRAP UP } & \\
\hline
\end{tabular}




\section{INITIAL TOT AGENDA (continued)}

Day 7

\begin{tabular}{|c|c|c|c|}
\hline Time & Session & Objectives & Facilitator \\
\hline $8.00-8.15$ & Energizer/Housekeeping & $\begin{array}{l}\text { - To provide participants with the experience of } \\
\text { energizers from the Energizer Manual/other } \\
\text { suggested energizers }\end{array}$ & \\
\hline $8.15-8.30$ & Feedback on Day 6 & $\begin{array}{l}\text { - To provide an ongoing evaluation of the } \\
\text { workshop }\end{array}$ & \\
\hline \multirow[t]{2}{*}{$8.30-10.30$} & $\begin{array}{l}\text { Information Session (FE Curriculum) } \\
\text { Introduction to Financial Education: } \\
\text { Why Financial Education for } \\
\text { adolescents? }\end{array}$ & $\begin{array}{l}\text { - To introduce the concepts of Financial } \\
\text { Education and why it is particularly important } \\
\text { for adolescent girls }\end{array}$ & \\
\hline & \multicolumn{2}{|r|}{ TEA BREAK } & \\
\hline $11.00-13.00$ & $\begin{array}{l}\text { Information Session (FE curriculum) } \\
\text { Introduction to Financial Education: } \\
\text { Do girls have money? }\end{array}$ & $\begin{array}{l}\text { To build participants' understanding of } \\
\text { concepts in financial education for } \\
\text { adolescents }\end{array}$ & \\
\hline $13.00-14.00$ & \multicolumn{2}{|r|}{ LUNCH } & \\
\hline $14.00-16.00$ & $\begin{array}{l}\text { Training Topic (FE curriculum) } \\
\text { Applied Learning approach: Initial } \\
\text { impressions of "Dream Big" }\end{array}$ & $\begin{array}{l}\text { - To provide an overview of an Applied } \\
\text { Learning approach to training } \\
\text { Modeled Delivery \#1 of a Financial Education } \\
\text { session-and introduction of "Anchor, Add, } \\
\text { Apply, Away" approach }\end{array}$ & \\
\hline $16.00-16.30$ & \multicolumn{2}{|r|}{ TEA BREAK } & \\
\hline $16.30-17.30$ & $\begin{array}{l}\text { Training Topic (FE Curriculum) } \\
\text { Active Learning approach: Why } \\
\text { save? }\end{array}$ & $\begin{array}{l}\text { - Modeled Delivery \#2 of a Financial Education } \\
\text { session-with a focus on "anchoring" and } \\
\text { "add" techniques } \\
\text { - } \quad \text { Teams assigned Practical Sessions (4 Teams) }\end{array}$ & \\
\hline $17: 30$ & \multicolumn{2}{|r|}{ WRAP UP } & \\
\hline
\end{tabular}


Day 8

\begin{tabular}{|c|c|c|c|}
\hline Time & Session & Objectives & Facilitator \\
\hline $8.00-8.15$ & Energizer/Housekeeping & $\begin{array}{l}\text { - To provide participants with the experience of } \\
\text { energizers from the Energizer Manual/other } \\
\text { suggested energizers }\end{array}$ & \\
\hline $8.15-8.30$ & Feedback on Day 7 & $\begin{array}{l}\text { - To provide an ongoing evaluation of the } \\
\text { workshop }\end{array}$ & \\
\hline $8.30-10.30$ & $\begin{array}{l}\text { Training Topic (FE Curriculum) } \\
\text { Modeled delivery: Make a Savings } \\
\text { Plan (Session 4) }\end{array}$ & $\begin{array}{l}\text { - Modeled Delivery } 3 \text { of an FE session-with a } \\
\text { focus on "apply" and "away" techniques }\end{array}$ & \\
\hline $10.30-11.00$ & \multicolumn{2}{|r|}{ TEA BREAK } & \\
\hline $11.00-13.00$ & $\begin{array}{l}\text { Training Topic (FE Curriculum) } \\
\text { Modeled delivery: Constructive } \\
\text { Feedback }\end{array}$ & $\begin{array}{l}\text { - "Giving and taking feedback"-and a few key } \\
\text { pointers on preparing for Practice Sessions } \\
\text { - } \quad \text { Preparation time for Practical Session }\end{array}$ & \\
\hline $13.00-14.00$ & \multicolumn{2}{|r|}{ LUNCH BREAK } & \\
\hline $14.00-16.00$ & $\begin{array}{l}\text { Practical Session (FE } \\
\text { Curriculum) } \\
\text { Participants present their topics } \\
\text { - Team 1: Choose a Savings Goal } \\
\quad \text { (session 3) } \\
\text { - Team 2: Exploring Options for } \\
\quad \text { Earning Money (Session 6) } \\
\text { Practical session group } \\
\text { feedback }\end{array}$ & $\begin{array}{l}\text { - } \quad \text { Participants practice facilitation skills } \\
\text { - } \quad \text { Participants practice giving and taking } \\
\text { - } \quad \text { Participack } \\
\text { - } \quad \text { Parfectively facilitate } \\
\text { during facilitation }\end{array}$ & \\
\hline $16.00-16.30$ & \multicolumn{2}{|r|}{ TEA BREAK } & \\
\hline $16.30-18.30$ & $\begin{array}{l}\text { Practical Session (Financial } \\
\text { Education) } \\
\text { Participants present their topics } \\
\text { - Team 3: Girls Money and the } \\
\quad \text { Risky Income Cycle (Session 7) } \\
\text { - Team 4: Think About the Future, } \\
\text { Money In Money Out } \\
\quad \text { (Session 10) } \\
\text { Practical Session } \\
\text { De-Briefing }\end{array}$ & 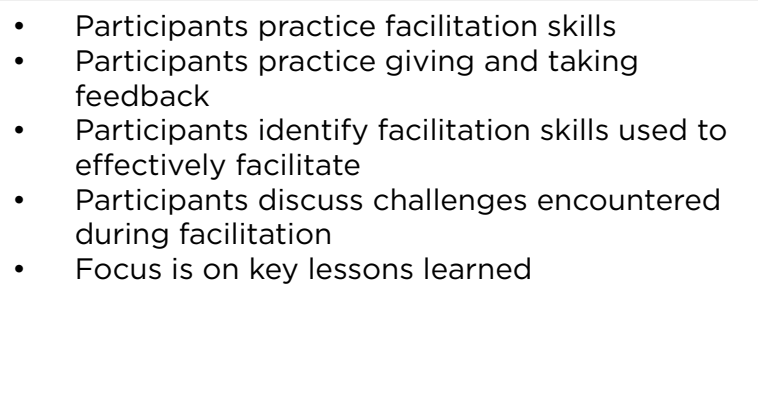 & \\
\hline & \multicolumn{2}{|r|}{ WRAP UP } & \\
\hline
\end{tabular}




\section{INITIAL TOT AGENDA (continued)}

\section{Day 9}

\begin{tabular}{|c|c|c|c|}
\hline Time & Session & Objectives & Facilitator \\
\hline $8.00-8.15$ & Energizer/Housekeeping & $\begin{array}{l}\text { - To provide participants with the experience of } \\
\text { energizers from the Energizer Manual/other } \\
\text { suggested energizers }\end{array}$ & \\
\hline $8.15-8.30$ & Feedback on Day 8 & $\begin{array}{l}\text { - To provide an ongoing evaluation of the } \\
\text { workshop }\end{array}$ & \\
\hline $8.30-10.30$ & Introduction to safety mapping & $\begin{array}{l}\text { - Participants understand the importance of } \\
\text { safety mapping for girls groups } \\
\text { Participants learn safety mapping } \\
\text { exercise }\end{array}$ & \\
\hline $10.30-11.00$ & \multicolumn{2}{|r|}{ TEA BREAK } & \\
\hline $11.00-13.00$ & $\begin{array}{l}\text { Mentor role in } \underline{[\text { Program name }]} \\
\text { (invitation delivery, intro } \\
\text { meeting, safe space meetings, } \\
\text { and girls recruitment and } \\
\text { retention) }\end{array}$ & $\begin{array}{l}\text { - Recap on the role of mentors } \\
\text { Explain the process of invitation delivery and } \\
\text { the role of mentors } \\
\text { Introduce the recruitment and retention } \\
\text { protocol } \\
\text { - Introduce the bridge model }\end{array}$ & \\
\hline $13.00-14.00$ & \multicolumn{2}{|r|}{ LUNCH BREAK } & \\
\hline $14.00-15.00$ & Monitoring and Evaluation & $\begin{array}{ll}\text { - } & \text { Introduce monitoring and evaluation tools } \\
\text { - } & \text { Registers/Attendance } \\
\text { - } & \text { Reports } \\
\text { - } & \text { Lesson plans }\end{array}$ & \\
\hline $15.00-16.30$ & Evaluation and Next Steps & $\begin{array}{l}\text { - To summarize the achievements of the } \\
\text { workshop } \\
\text { To explain what is expected of the mentors } \\
\text { going forward }\end{array}$ & \\
\hline \multirow[t]{2}{*}{$16.30-17.00$} & Post-test questionnaire & $\begin{array}{l}\text { - To measure the levels of knowledge gained by } \\
\text { participants from participating in the training }\end{array}$ & \\
\hline & Closing Ceremony & & \\
\hline
\end{tabular}




\section{TRAINING-OF-TRAINERS AGENDA: FACILITATING GROUPS AND COMMUNITY ENGAGEMENT}

This sample agenda from a 10-day training of mentors provides a different example of how to organize an introductory workshop that is slightly longer. It focuses more on community engagement because it comes from a community-based, rather than school-based, program.

This agenda includes time to discuss the research that was conducted as part of the project. The objectives of the workshop were to enable participants to acquire comprehensive understanding of the concepts of the program, to gain accurate information related to the curricula, and to gain and practice skills in participatory methods to be used in the safe space sessions.

\section{Objectives:}

The overall objective of the training is to build the capacity of mentors in facilitating safe spaces groups and effectively delivering health, life skills, financial education, and gender norms to the girls in the program. The specific objectives of the training are to enable participants to:

- Acquire comprehensive understanding of the concepts of the program.

- Acquire accurate information on the curriculum

- Acquire practical skills to facilitate a range of interactive methodologies to be used during the safe space sessions.

Expected outcome: Confident, competent mentors with skills to implement safe-space activities and deliver sessions on health, life skills, financial education, and gender norms. 


\section{TOT AGENDA: FACILITATING GROUPS AND COMMUNITY ENGAGEMENT (continued)}

Day 1

\begin{tabular}{|c|c|c|c|}
\hline Time & Session & Objectives & Facilitator \\
\hline $8.30-9.00$ & $\begin{array}{l}\text { Registration, climate } \\
\text { setting/introductions/ } \\
\text { training program and } \\
\text { training logistics }\end{array}$ & $\begin{array}{l}\text { - } \quad \text { Acquire participants' contact details } \\
\text { - } \quad \text { Share training logistics }\end{array}$ & \\
\hline $9.00-10.00$ & $\begin{array}{l}\text { Training objectives/ } \\
\text { ground rules } \\
\text { Participants' expectations }\end{array}$ & $\begin{array}{l}\text { Take participants through the training } \\
\text { objectives and training program }\end{array}$ & \\
\hline $10.00-10.30$ & & TEA BREAK & \\
\hline $10.30-11.30$ & $\begin{array}{l}\text { Brief background } \\
\text { of implementing } \\
\text { organization, program, } \\
\text { research design, and } \\
\text { objectives, including } \\
\text { intervention components }\end{array}$ & $\begin{array}{l}\text { - Gain an understanding of work of implementing } \\
\text { organization } \\
\text { Gain an understanding of the program's objective, } \\
\text { theory of change, and research and program } \\
\text { components }\end{array}$ & \\
\hline $11.30-12: 30$ & Mentorship and its roles & $\begin{array}{l}\text { - Gain understanding on what mentorship is, why } \\
\text { become a mentor, roles of a mentor, qualities and } \\
\text { responsibilities, specific roles of the mentors in the } \\
\text { program }\end{array}$ & \\
\hline $12.30-13.00$ & $\begin{array}{l}\text { Introduce the concept of } \\
\text { ice breakers and energiz- } \\
\text { er activities }\end{array}$ & $\begin{array}{l}\text { - Understand the role of using ice breakers/energizer } \\
\text { activities in groups } \\
\text { - Practice different types of activities }\end{array}$ & \\
\hline $13.00-14.00$ & & LUNCH BREAK & \\
\hline $14.00-15.00$ & $\begin{array}{l}\text { Understanding the con- } \\
\text { cept of full engagement } \\
\text { with girl participants }\end{array}$ & $\begin{array}{l}\text { Practice engagement language, develop list of } \\
\text { techniques to promote safe space for learning, } \\
\text { giving praise; practice open-ended questions versus } \\
\text { closed questions }\end{array}$ & \\
\hline $15.00-16.00$ & Team/trust building & $\begin{array}{l}\text { - Create trust and promote team work among group } \\
\text { members; practice team-building exercises }\end{array}$ & \\
\hline $16.00-16.30$ & Wrap up & - $\quad$ Participants evaluate the day's session. & \\
\hline
\end{tabular}

Day 2

\begin{tabular}{|l|l|l|l|}
\hline Time & Session & Objectives & Facilitator \\
\hline $8.00-8.30$ & Recap of previous day & $\begin{array}{l}\text { Participants refreshed on previous day's content and } \\
\text { review agenda for Day 2 }\end{array}$ & $\begin{array}{l}\text { To highlight needs of different key segments of girls } \\
\text { and how to overcome challenges of fully engaging } \\
\text { them }\end{array}$ \\
\hline 8.30-9.30 & Reading your audience & $\begin{array}{l}\text { Identify different segments of girls, develop list of } \\
\text { key stakeholders in working with different segments } \\
\text { of girls, identify challenges in working with them and } \\
\text { how to overcome them }\end{array}$ & $\begin{array}{l}\text { Working with girls/how to } \\
\text { rally for their support }\end{array}$ \\
\hline $10.30-10.45$ & Value clarification & $\begin{array}{l}\text { Texplore and clarify participants' beliefs and attitudes } \\
\text { toward reproductive health issues among } \\
\text { adolescent girls } \\
\text { Use agree, disagree, not sure model }\end{array}$ \\
\hline
\end{tabular}




\begin{tabular}{|c|c|c|}
\hline $12.00-13.00$ & $\begin{array}{l}\text { Facilitation skills-building } \\
\text { for desired change }\end{array}$ & $\begin{array}{l}\text { Understand the role of facilitation } \\
\text { Facilitation techniques } \\
\text { Qualities of a good facilitator } \\
\text { - Group work: Identify unique needs of vulnerable } \\
\text { adolescent girls } \\
\text { Highlight facilitation skills most appropriate to } \\
\text { unique needs of adolescent girls }\end{array}$ \\
\hline $13.00-14.00$ & & LUNCH BREAK \\
\hline $14.00-15.00$ & Group dynamics & $\begin{array}{l}\text { Understand challenges and how to manage groups, } \\
\text { facilitate groups, maintain girls in a group, } \\
\text { conflict resolution in working with girls/guardians } \\
\text { and community at large }\end{array}$ \\
\hline $15.00-16.00$ & Safety planning & $\begin{array}{l}\text { - Understand what a safe space is, how to identify safe } \\
\text { spaces and design safe routes to get there } \\
\text { Group work: Brainstorm on possible safe spaces in } \\
\text { the community }\end{array}$ \\
\hline $16.00-16.30$ & $\begin{array}{l}\text { Distribution of the } \\
\text { curricula for review }\end{array}$ & \\
\hline $16.30-17.00$ & & WRAP UP AND CLOSURE \\
\hline
\end{tabular}

\section{Day 3}

\begin{tabular}{|c|c|c|c|}
\hline Time & Session & Objective & Facilitator \\
\hline $8.00-8.30$ & Recap of previous day & $\begin{array}{l}\text { - Participants are refreshed on previous day's content } \\
\text { and go over agenda for Day } 3\end{array}$ & \\
\hline $8.30-9.30$ & $\begin{array}{l}\text { Setting up a referral } \\
\text { system }\end{array}$ & $\begin{array}{l}\text { - Understand what referral is and what } \\
\text { services are needed for } \\
\text { through the list of available services in the } \\
\text { community }\end{array}$ & \\
\hline $9.30-10.30$ & $\begin{array}{l}\text { Overview of Health and } \\
\text { Life Skills curriculas }\end{array}$ & $\begin{array}{l}\text { - Review the Health curriculum including } \\
\text { structure, topics, and flow of sessions } \\
\text { - Identify challenging topics }\end{array}$ & \\
\hline $10.30-11.00$ & & TEA BREAK & \\
\hline $11.00-12.00$ & $\begin{array}{l}\text { Overview of Financial } \\
\text { Education curriculum }\end{array}$ & $\begin{array}{l}\text { - Review the Financial Education curriculum, } \\
\text { including structure, topics, and flow of } \\
\text { sessions } \\
\text { - Identify challenging topics }\end{array}$ & \\
\hline $12.00-13.00$ & $\begin{array}{l}\text { Overview of Gender } \\
\text { Norms curriculum }\end{array}$ & $\begin{array}{l}\text { Review the Gender Norms curriculum including struc- } \\
\text { ture, topics, and flow of sessions } \\
\text { Identify challenging topics }\end{array}$ & \\
\hline $13.00-14.00$ & & LUNCH BREAK & \\
\hline $14.00-15.00$ & Being assertive & & \\
\hline $15.00-16.00$ & $\begin{array}{l}\text { Managing stress, anger, } \\
\text { and conflict }\end{array}$ & & \\
\hline $16.00-16.30$ & & WRAP UP & \\
\hline
\end{tabular}




\section{TOT AGENDA: FACILITATING GROUPS AND COMMUNITY ENGAGEMENT (continued)}

Day 4

\begin{tabular}{|c|c|c|c|}
\hline Time & Session & Objective & Facilitator \\
\hline $8.00-8.30$ & Recap of previous day & $\begin{array}{l}\text { Participants are refreshed on previous day's } \\
\text { content and go over agenda for Day } 4\end{array}$ & \\
\hline $8.30-9.30$ & $\begin{array}{l}\text { Know the difference } \\
\text { between needs and wants }\end{array}$ & & \\
\hline $10.30-11.00$ & & TEA BREAK & \\
\hline $11.00-12.00$ & $\begin{array}{l}\text { Exploring options for } \\
\text { earning money }\end{array}$ & & \\
\hline $12.00-13.00$ & Adolescence and puberty & & \\
\hline $13.00-14.00$ & & LUNCH BREAK & \\
\hline $14.00-15.00$ & Sexuality and behavior & & \\
\hline $15.00-16.00$ & $\begin{array}{l}\text { Young people and } \\
\text { contraceptives }\end{array}$ & & \\
\hline $16.00-16.30$ & \multicolumn{2}{|c|}{ WRAP UP AND CLOSURE } & \\
\hline
\end{tabular}

Day 5

\begin{tabular}{|c|c|c|c|}
\hline Time & Session & Objective & Facilitator \\
\hline $8.00-8.30$ & Recap of previous day & $\begin{array}{l}\text { Participants are refreshed on previous day's } \\
\text { content and go over agenda for Day } 5\end{array}$ & \\
\hline $8.30-9.30$ & Teenage pregnancy & & \\
\hline $9.30-10.30$ & $\begin{array}{l}\text { Drugs and substance } \\
\text { abuse }\end{array}$ & & \\
\hline $10.30-11.00$ & & TEA BREAK & \\
\hline $11.00-12.00$ & $\begin{array}{l}\text { Becoming a gender } \\
\text { champion }\end{array}$ & & \\
\hline $12.00-13.00$ & Learning about banks & & \\
\hline $13.00-14.00$ & & LUNCH BREAK & \\
\hline $14.00-15.00$ & Bank account & & \\
\hline $15.00-16.00$ & $\begin{array}{l}\text { Dealing with setbacks in } \\
\text { savings }\end{array}$ & & \\
\hline $16.00-16.30$ & \multicolumn{2}{|c|}{ WRAP UP AND CLOSURE } & \\
\hline
\end{tabular}

Day 6

\begin{tabular}{|l|l|l|l|}
\hline Time & Session & Objective & Facilitator \\
\hline $8.00-8.30$ & Recap of previous day & $\begin{array}{l}\text { Participants are refreshed on previous day's } \\
\text { content and go over agenda for Day 6 }\end{array}$ & \\
\hline $8.30-9.30$ & Understanding gender & & \\
\hline $9.30-10.30$ & $\begin{array}{l}\text { Understanding power and } \\
\text { status }\end{array}$ & & \\
\hline $10.30-11.00$ & \multicolumn{2}{|c|}{ TEA BREAK } & \\
\hline $11.00-12.00$ & $\begin{array}{l}\text { Understanding violence } \\
\text { against women and girls }\end{array}$ & & \\
\hline $12.00-13.00$ & An ideal community & & \\
\hline
\end{tabular}




\begin{tabular}{|l|l|l|l|}
\hline $13.00-14.00$ & & \\
\hline $14.00-15.00$ & $\begin{array}{l}\text { Review of identified } \\
\text { difficult topic }\end{array}$ & $\begin{array}{l}\text { LUNCH BREAK } \\
\text { constructive feedback }\end{array}$ & $\begin{array}{l}\text { Acquire practical skills of providing } \\
\text { constructive feedback }\end{array}$ \\
\hline $15.00-16.00$ & \multicolumn{2}{|c|}{ WRAP UP AND CLOSURE } \\
\hline $16.00-16.30$ & & \\
\hline
\end{tabular}

\section{Day 7}

\begin{tabular}{|c|c|c|c|}
\hline Time & Session & Objective & Facilitator \\
\hline $8.00-8.30$ & Recap of previous day & $\begin{array}{l}\text { - Participants are refreshed on previous } \\
\text { day's content and go over agenda for } \\
\text { Day } 7\end{array}$ & \\
\hline $8.30-10.30$ & $\begin{array}{l}\text { Assigning of practical } \\
\text { sessions and practice }\end{array}$ & $\begin{array}{l}\text { - Assignment-participants to peruse } \\
\text { Health and Life Skills, Financial Education } \\
\text { and Gender Norms curricula and note } \\
\text { questions/comments to be discussed } \\
\text { - Assign participants practical sessions- } \\
\text { assess participants' facilitation skills. } \\
\text { Divide participants into } 7 \text { teams of } 3\end{array}$ & \\
\hline $10.30-11.00$ & & TEA BREAK & \\
\hline $11.00-12.30$ & $\begin{array}{l}\text { Practical Session } \\
\text { Participants present their } \\
\text { topics: } \\
\text { Team 1: [Session title] } \\
\text { Practical session group } \\
\text { feedback }\end{array}$ & $\begin{array}{l}\text { - Participants practice facilitation skills and } \\
\text { familiarize themselves with the } \\
\text { curricula } \\
\text { - Participants identify facilitation skills } \\
\text { used to effectively facilitate } \\
\text { - Participants discuss challenges } \\
\text { encountered during facilitation }\end{array}$ & \\
\hline $12.30-13.30$ & & LUNCH BREAK & \\
\hline $13.30-14.30$ & $\begin{array}{l}\text { Practical Session } \\
\text { Participants present their } \\
\text { topics. } \\
\text { Team 2: [Session title] } \\
\text { Practical session group } \\
\text { feedback }\end{array}$ & $\begin{array}{l}\text { - Participants practice facilitation skills and } \\
\text { familiarize themselves with the } \\
\text { curricula } \\
\text { - Participants identify facilitation skills } \\
\text { used to effectively facilitate } \\
\text { - Participants discuss challenges } \\
\text { encountered during facilitation }\end{array}$ & \\
\hline $14.30-16.00$ & $\begin{array}{l}\text { Practical Session } \\
\text { Participants present their } \\
\text { topics: } \\
\text { Team 3: [Session title] } \\
\text { Practical session group } \\
\text { feedback }\end{array}$ & $\begin{array}{l}\text { - Participants practice facilitation skills and } \\
\text { familiarize themselves with the } \\
\text { curricula } \\
\text { - Participants identify facilitation skills } \\
\text { used to effectively facilitate } \\
\text { - Participants discuss challenges } \\
\text { encountered during facilitation }\end{array}$ & \\
\hline $16.00-16.30$ & \multicolumn{2}{|c|}{ WRAP UP AND CLOSURE } & \\
\hline
\end{tabular}




\section{TOT AGENDA: FACILITATING GROUPS AND COMMUNITY ENGAGEMENT (continued)}

Day 8

\begin{tabular}{|c|c|c|c|}
\hline Time & Session & Objective & Facilitator \\
\hline $8.00-8.30$ & Recap of previous day & $\begin{array}{l}\text { - Participants refreshed on previous day's } \\
\text { content and go over agenda for Day } 8\end{array}$ & \\
\hline $8.30-10.30$ & $\begin{array}{l}\text { Practical Session } \\
\text { Participants present their } \\
\text { topics: } \\
\text { Team 3: [Session title] } \\
\text { Practical session group } \\
\text { feedback }\end{array}$ & $\begin{array}{l}\text { - Participants practice facilitation skills and } \\
\text { familiarize themselves with the curricula } \\
\text { - Participants identify facilitation skills used to } \\
\text { effectively facilitate } \\
\text { - Participants discuss challenges } \\
\text { encountered during facilitation }\end{array}$ & \\
\hline $10.30-11.00$ & & TEA BREAK & \\
\hline $11.00-12.30$ & $\begin{array}{l}\text { Practical Session } \\
\text { Participants present their } \\
\text { topics: } \\
\text { Team 4: [Session title] } \\
\text { Practical session group } \\
\text { feedback }\end{array}$ & $\begin{array}{l}\text { - Participants practice facilitation skills and } \\
\text { familiarize themselves with the } \\
\text { curricula } \\
\text { Participants identify facilitation skills used to } \\
\text { effectively facilitate }\end{array}$ & \\
\hline $12.30-13.30$ & & LUNCH BREAK & \\
\hline $13.30-14.30$ & $\begin{array}{l}\text { Practical Session } \\
\text { Participants present their } \\
\text { topics: } \\
\text { Team 5: [Session title] } \\
\text { Practical session group } \\
\text { feedback }\end{array}$ & $\begin{array}{l}\text { - Participants practice facilitation skills and } \\
\text { familiarize themselves with the curricula } \\
\text { - Participants identify facilitation skills used to } \\
\text { effectively facilitate } \\
\text { - Participants discuss challenges encountered } \\
\text { during facilitation }\end{array}$ & \\
\hline $14.30-16.00$ & $\begin{array}{l}\text { Practical Session } \\
\text { Participants present their } \\
\text { topics: } \\
\text { Team 6: [Session title] } \\
\text { Practical session group } \\
\text { feedback }\end{array}$ & $\begin{array}{l}\text { - Participants practice facilitation skills and } \\
\text { familiarize themselves with the } \\
\text { curricula }\end{array}$ & \\
\hline $16.00-16.30$ & \multicolumn{2}{|r|}{ WRAP UP AND CLOSURE } & \\
\hline
\end{tabular}

Day 9

\begin{tabular}{|c|c|c|c|}
\hline Time & Session & Objectives & Facilitator \\
\hline $8.00-8.15$ & Energizer/Housekeeping & $\begin{array}{l}\text { - To provide participants with the experience } \\
\text { of energizers from the Energizer Manual/ } \\
\text { other suggested energizers }\end{array}$ & \\
\hline $8.15-8.30$ & Feedback on Day 8 & $\begin{array}{l}\text { - To provide an ongoing evaluation of the } \\
\text { workshop }\end{array}$ & \\
\hline $8.30-10.30$ & $\begin{array}{l}\text { Introduction to safety } \\
\text { mapping }\end{array}$ & $\begin{array}{l}\text { - Participants understand the importance of } \\
\text { safety mapping for girl groups } \\
\text { - } \quad \text { Participants learn safety mapping exercise }\end{array}$ & \\
\hline $10.30-11.00$ & & Tea break & \\
\hline
\end{tabular}




\begin{tabular}{|c|c|c|}
\hline $11.00-13.00$ & $\begin{array}{l}\text { Mentor roles of the } \\
\text { program: invitation } \\
\text { delivery, intro meeting, safe } \\
\text { space meetings, and girls } \\
\text { recruitment and retention }\end{array}$ & $\begin{array}{l}\text { - Recap on the role of mentors } \\
\text { Explain the process of invitation delivery and } \\
\text { the role of mentors } \\
\text { Introduce the recruitment and retention } \\
\text { protocol } \\
\text { - Introduce the bridge model }\end{array}$ \\
\hline $13.00-14.00$ & \multicolumn{2}{|r|}{ LUNCH BREAK } \\
\hline $14.00-15.00$ & Monitoring and evaluation & $\begin{array}{ll}\text { - } & \text { Introduce monitoring and evaluation tools } \\
\text { - } & \text { Registers/Attendance } \\
\text { - } & \text { Reports } \\
\text { Lesson plans }\end{array}$ \\
\hline $15.00-16.30$ & Evaluation and next steps & $\begin{array}{l}\text { - To summarize the achievements of the } \\
\text { workshop } \\
\text { To explain what is expected of the } \\
\text { mentors going forward }\end{array}$ \\
\hline \multirow[t]{2}{*}{$16.30-17.00$} & Post-test questionnaire & $\begin{array}{l}\text { - To measure the levels of knowledge gained } \\
\text { by participants from participating in the } \\
\text { training }\end{array}$ \\
\hline & \multicolumn{2}{|r|}{ CLOSING CEREMONY } \\
\hline
\end{tabular}

Day 10

\begin{tabular}{|l|l|l|l|}
\hline TIME & SESSION & OBJECTIVE & Facilitator \\
\hline $8.00-8.30$ & Recap of previous day & $\begin{array}{l}\text { Participants are refreshed on previous day's } \\
\text { content and go over agenda for Day 10 }\end{array}$ & \\
\hline $8.30-10.30$ & $\begin{array}{l}\text { Mobile phone data- } \\
\text { collection training }\end{array}$ & \multicolumn{1}{|c|}{ TEA BREAK } & \\
\hline $10.30-11.00$ & \multicolumn{1}{|c|}{ LUNCH BREAK } & \\
\hline $11.00-13.00$ & $\begin{array}{l}\text { Mobile phone data- } \\
\text { collection practice }\end{array}$ & & \\
\hline $13.00-14.00$ & \multicolumn{3}{|l|}{} \\
\hline $14.00-15.00$ & $\begin{array}{l}\text { Participant recruitment/ } \\
\text { Introductory meetings }\end{array}$ & $\begin{array}{l}\text { Participant valuation/ } \\
\text { Next steps and closure }\end{array}$ & \\
\hline $15.00-16.00$ & &
\end{tabular}




\section{DAILY EVALUATION FORM}

It may take only a few questions to learn how effective the training is. These five questions were posed to mentors at the end of each day of a multi-day training session to assess what mentors learned and valued from the training. Having trainees reflect at the end of each day allows facilitators to make changes for the following days and put more emphasis on areas that need more explanation. These questions can be printed and handed out, or each participant can answer on a post-it or index card, with responses numbered.

\section{Date:}

1. What did you enjoy most about today?

2. What did you learn during today's sessions that you anticipate using in your work?

3. Was there anything you did not understand during today's sessions? Please provide specific examples.

4. What is the most valuable thing you learned today (knowledge or skills)?

5. Is there anything else you would like us to know? 


\section{MONTHLY MENTOR MEETING AGENDA}

After an initial training, it is usually helpful to bring mentors together regularly, for example every month, to discuss with each other (and with a supervisor) what is happening in their groups and any issues they may need help with. Monthly meetings are an important time for mentors to build their skills and learn from each other. Below is a sample agenda from monthly meetings for mentor support. It includes an update on safe space meetings from the previous month, successes, challenges, suggested solutions, experiences with home visits, review of the curriculum sessions from the previous month, collection of success stories, attendance tool overview, training for upcoming sessions, and review of submission of monthly reports.

\begin{tabular}{|c|c|c|}
\hline Time & Agenda Item & Facilitator \\
\hline $9.05-9.10$ & Welcome/Introduction & \\
\hline $9.10-11.00$ & $\begin{array}{l}\text { Updates on safe space meetings from the previous month, including } \\
\text { successes, challenges, suggested solutions, and experiences with home } \\
\text { visits conducted. Record this for each session in site coordinator monthly } \\
\text { report so that we can collect feedback for all sessions from all sites. }\end{array}$ & \\
\hline $11.00-11.45$ & $\begin{array}{l}\text { Review of curriculum sessions facilitated in the previous month looking at } \\
\text { the following areas: } \\
\text { - Unclear directions in the curriculum } \\
\text { - Level of interest/engagement of girls/parents } \\
\text { - Overall understanding of the topic by the end of the session } \\
\text { - Time allocated for exercises } \\
\text { - Challenges/suggested adaptations }\end{array}$ & \\
\hline $11.45-12.10$ & $\begin{array}{l}\text { Success stories from mentors } \\
\text { - } \quad \text { Challenges faced } \\
\text { - } \quad \text { Criteria } \\
\text { - Possible follow-ups }\end{array}$ & \\
\hline $12.10-12.30$ & $\begin{array}{l}\text { Review of attendance tool } \\
\text { - Missing meetings } \\
\text { - New additions } \\
\text { - } \quad \text { Form verification (if using electronic data collection) }\end{array}$ & \\
\hline $12.30-13.00$ & BREAK & \\
\hline
\end{tabular}




\section{MONTHLY MENTOR MEETING AGENDA (continued)}

\begin{tabular}{|l|l|l|}
\hline 13:00-13:40 & Training on curriculum: Upcoming session & \\
\hline 13:40-14:10 & Community engagement meetings planning & \\
\hline 14:10-14:50 & Training on curriculum: Upcoming session & \\
\hline 14:50-15:20 & $\begin{array}{l}\text { Safe space graduation planning: Duration, structure, and guests (when } \\
\text { nearing the end of the program cycle) }\end{array}$ & \\
\hline 15:20-15:30 & Submission of monthly reports & \\
\hline 15:30-15:40 & Administrative-related matters & \\
\hline 15:40-16:00 & Any other business & \\
\hline
\end{tabular}




\section{TRAINING PRESENTATION: WHAT IS A MENTOR?}

This presentation can be used in an initial training with mentors to introduce the idea of mentoring. It covers the main components of mentoring, mentors in everyone's own lives, qualities of a good mentor, and benefits to mentors and girls. This presentation also includes an activity that describes nine principles of a successful mentoring relationship (see "Nine Acts" Cards in following section).

\section{What is Mentoring?}

-Building, maintaining, and growing a relationship of mutual responsibility and accountability.

-Sharing knowledge, skills, and experience.

-Providing guidance in developing self-awareness and skills.

- Creating an opportunity to ask questions, share concerns, and observe a more experienced professional within a safe, protected environment.

Slide 1

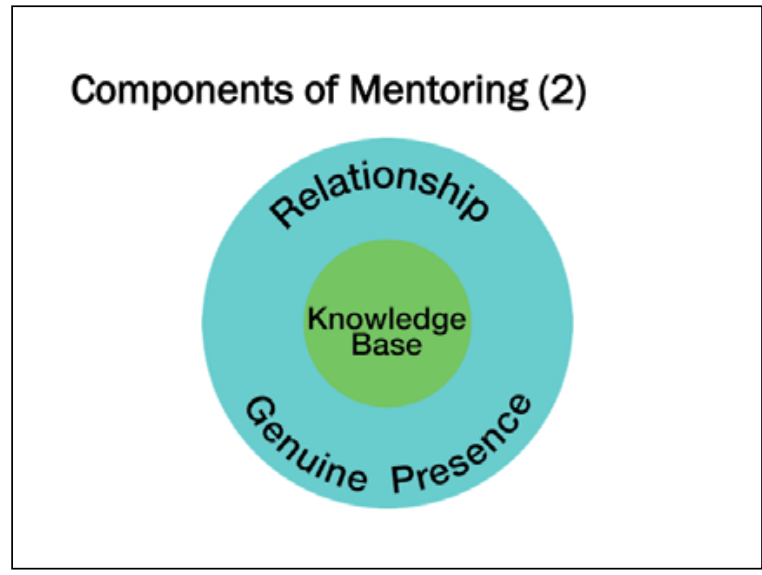

Slide 3

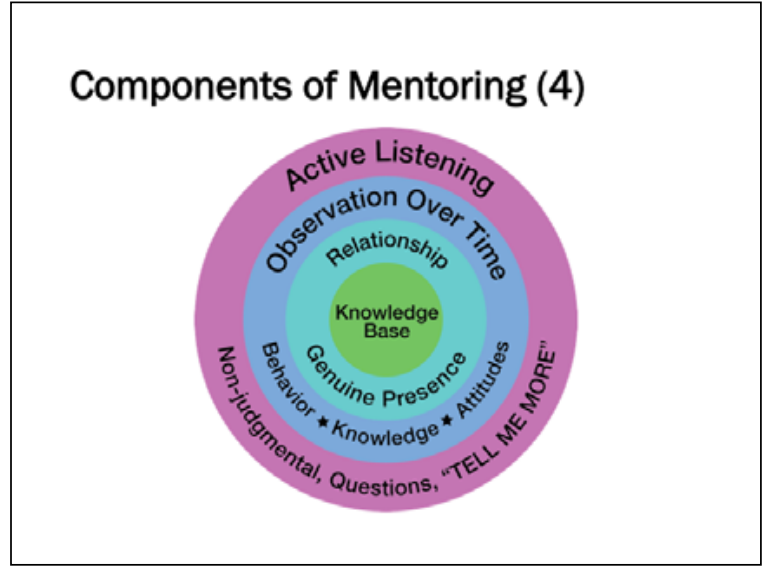

Slide 5

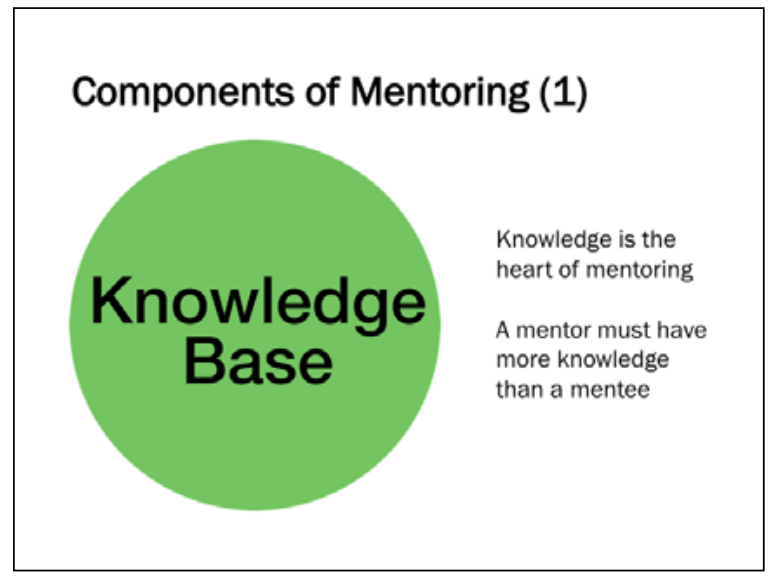

Slide 2

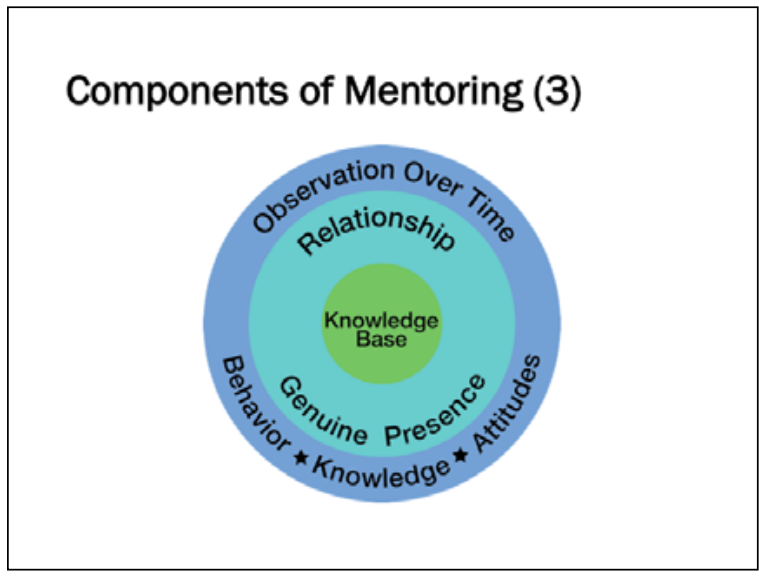

Slide 4

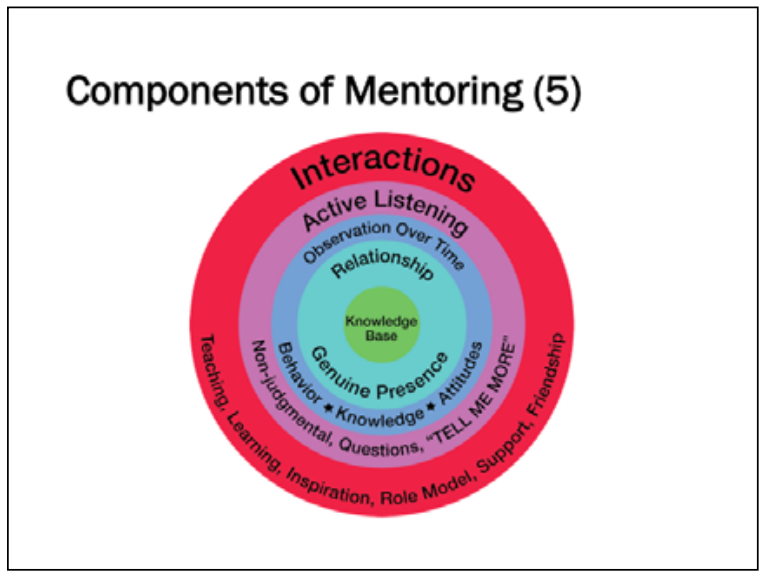

Slide 6 


\section{TRAINING PRESENTATION: WHAT IS A MENTOR? (continued)}

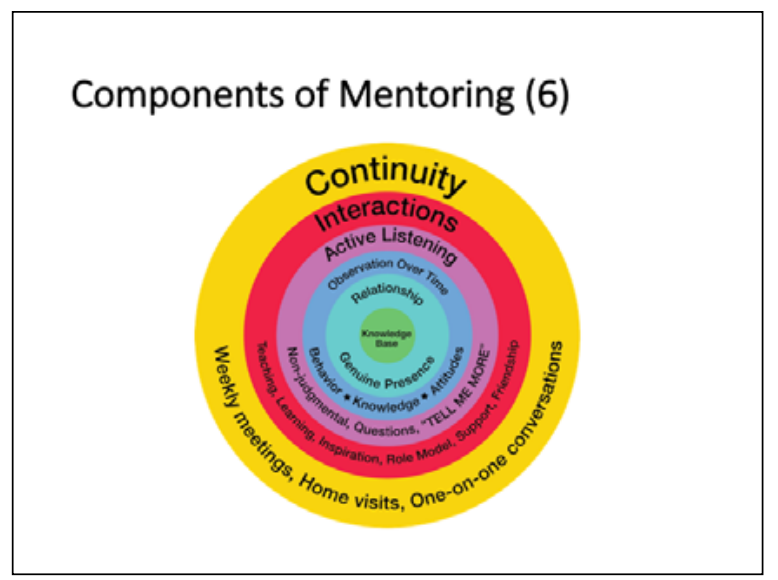

Slide 7

\section{Qualities of a Good Mentor (1)}

-Willingness to share skills, knowledge and expertise.

- Demonstrates a positive attitude and acts as a positive role model.

- Takes a personal interest in the mentoring relationship.

- Exhibits enthusiasm about the mentor position.

\section{Benefits of the Mentoring Relationship}

\section{Benefits to Mentors}

-Satisfaction and inspiration in helping your mentee define and achieve her goals and objectives

-An opportunity to improve interpersonal communication, motivation, coaching, counseling, and leadership skills

-An opportunity to impart valuable information, expertise, and wisdom to a receptive, more junior individual

\section{Mentors in Our Own Lives}

-Think about your own life. Have you ever had a mentor?

- If so, ask participants to share with the group and explain how their mentor had an impact on their lives.

- Ask the group to think about the qualities their mentors possessed and discuss.

Slide 8

\section{Qualities of a Good Mentor (2)}

- Provides guidance and constructive feedback.

- Respected by colleagues/community members.

-Values the opinions and initiatives of others.

- Trustworthy.

\section{Benefits of the Mentoring Relationship}

\section{Benefits to Mentees}

- Development of an interpersonal relationship with a caring, informed, supportive advisor

- Guidance in understanding a number of issues

-Ability to receive constructive feedback

-Direction in defining and achieving life goals 


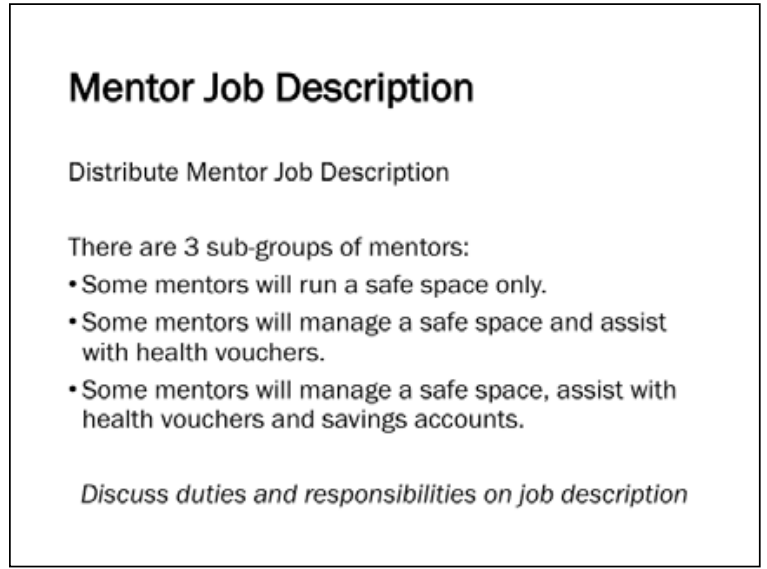

Slide 13

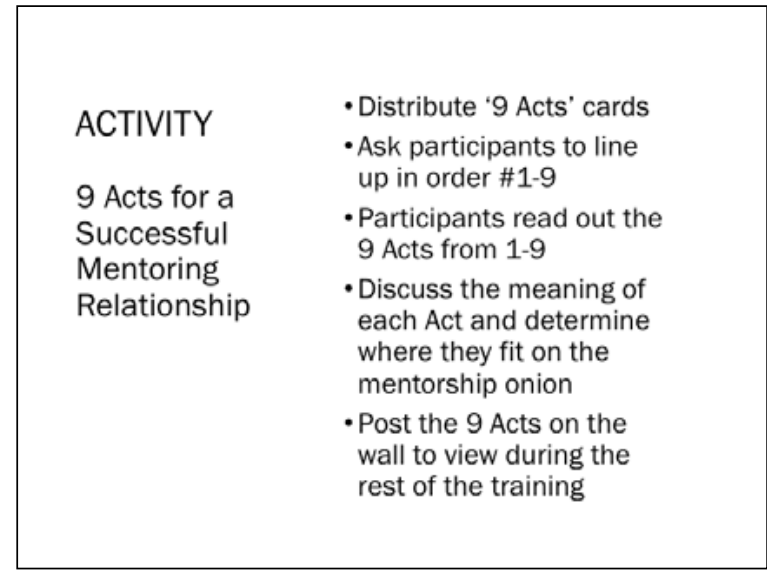

Slide 14

\section{"Nine Acts" Cards}

This describes an activity that can be done as part of mentor training outlining nine key principles of a successful mentoring relationship. Cards should be printed large enough to be visible as a reminder on the wall during the training.

\section{\#1: BE PROACTIVE}

Don't wait for the girls to contact you.

\section{\#4: BE CONFIDENT}

Each of you has something important to offer the other.

\section{\#7: BE RESPONSIVE}

Act upon what you've planned.

\section{\#2: NEGOTIATE A COMMITMENT}

Agree to have regular contact at set times.

\#5: COMMUNICATE

Share your knowledge and experience openly.

\#8: BE ACCESSIBLE

Have an open-door or open-phone policy.
\#3: ESTABLISH A RAPPORT

Learn as much as you can about one another.

\#6: BE A GOOD LISTENER

Hear what the girls are saying to you.

\section{\#9: TAKE RESPONSIBILITY}

It takes two to have a successful mentoring relationship. 


\section{TRAINING PRESENTATION: BASIC FACILITATION SKILLS}

This presentation can be used to introduce the basics of facilitation, which is a core part of mentoring and part of an introductory training. It describes the responsibilities of a facilitator, tips for working with groups, effective communication skills, group process techniques, active listening skills, and tips for dealing with difficult participants.

\section{What is Facilitation?}

Facilitation is the process where a facilitator guides the group members in meeting to share ideas, opinions, experiences, and expertise in order to achieve a common goal and agreeable plan of action

\section{The Facilitator}

- Does not evaluate ideas

- Helps the group focus its energies on a task

- Suggests methods and procedures

- Protects all members of the group from attack

- Helps find win/win solutions

- Makes sure that everyone has the opportunity to participate

- Periodically summarizes the group consensus on issues to validate and clarify the progress of the discussion

\section{Responsibilities of a Facilitator}

Some of the key responsibilities of a facilitator include the following:

- Helping the group clarify its goals or desired outcomes.

-Helping group members use the same tool at the same time on the same problem to accomplish its goals or outcomes. Sometimes this involvement means helping the group change directions and redefine its goals and desired outcomes.
Tips for working with groups

-Be aware of the physical environment and how it can influence group behavior.

-Things such as room setup, audiovisual needs, food or drink, distances between chairs, etc. If you are setting up the room, try arranging the chairs in a U-shaped semicircle, with the newsprint and the facilitator standing at the open end.

-Orient group to the timeframe and task at the beginning of each session. Make sure everyone understands the purpose of the meeting. 


\section{Tips for Working with Groups (cont.)}

-Explain the product that is expected (e.g., small group key points; group decisions, etc.)

-Develop group ground rules, or norms for operating, and use them. Examples include: We're all colleagues-let's respect each other; It's OK to disagree; Everyone participates, no one dominates; disregard $\mathrm{rank} / \mathrm{status.}$

-If you don't have a co-facilitator, select someone to write key points on the flipchart.

-If group is large, use name tents to remember everyone's name. People like being called by their first name.

\section{Effective Communication Skills for facilitators (cont.)}

- Modeling: Practice behavior that you want reflected back to you. Try to be nonjudgmental. Watch your nonverbal messages; remember to have some fun.

- Summarizing: Use paraphrasing as a method of clarifying. Check your perceptions with the group. For example: "Please correct me if I'm wrong, but I think Bob and Carmen's comments summarized our last 10 minutes quite well by stating...". It is very important to summarize at the end of key parts of the agenda and at the end of meetings.

\section{Effective Communication Skills for facilitators}

Communication skills are critical for a facilitator. How you

communicate, aside from the substance of the event, can make a difference in gaining support and moving things along efficiently and effectively. Some skill points for communicating include the following:

- Active listening: Be genuinely interested in other people's thoughts and feelings. Listen intently. Make eye contact.

\section{Communication...Critical Points}

- Active listening: Be genuinely interested in other people's thoughts and feelings. Listen intently. Make eye contact.

- Modeling: Practice behavior that you want reflected back to you Try to be nonjudgmental. Watch your nonverbal messages; remember to have some fun.

- Summarizing: Use paraphrasing as a method of clarifying. Check your perceptions with the group. For example: "Please correct me if I'm wrong, but I think Bob and Carmen's comments summarized our last 10 minutes quite well by stating...". It is very important to summarize at the end of key parts of the agenda and at the end of meetings.

\section{Communication...Critical Points (cont.)}

- Focusing attention and pacing: Keep the group on the topic and focused, using care to limit or reduce repetition. This is one of the facilitator's primary responsibilities. Stay on track!

- Recognizing progress: For example: "Nice job! We just brainstormed 36 items in that 4-minute time period."

- Waiting or Silence: Remember that sometimes the hardest thing to do is nothing.

\section{Communication...Critical Points (cont.)}

- Scanning/Observing: Nurture full participation from the group. Watch nonverbal cues in the form of body movement, facial expression, and gesture (may indicate loss of attention, confusion, or discontent)-take a break, change the pace, change the topic, etc.

- Inclusion: Make sure everyone has an equal opportunity to participate. Encourage those who have been silent to comment. For example, say in a humorous way: "I'm being rated by my client on the degree to which I get everyone to talk!" 


\section{TRAINING PRESENTATION: BASIC FACILITATION SKILLS}

\section{Body Language and Facilitation}

While we generally think of verbal skills as the most important facilitation skill, the role of nonverbal cues or body language is also critical to facilitative leadership. In a meeting, these nonverbal messages are constantly flowing from team member to facilitator and vice versa.

\section{Group Process Techniques}

Brainstorming Procedure:

Clarify the question or topic to be brainstormed.

Set a time limit.

Review the rules or post them.

Quantity, not quality, is the goal.

Defer all judgment until the process is over You are encouraged to further other people's ideas All ideas are recorded. This is a good allpurpose technique for generating a variety of options or alternatives.

\section{Group Process Techniques (cont.)}

\section{Response rounds Procedure:}

Give the group members a task/question to work on individually.

Ask members to respond one at a time. People are allowed to pass. Record responses. Repeat until people run out of responses.

Summarize each round of responses if it seems appropriate. This is good to use if you expect a moderately high level of conflict to exist when the group discusses a particular topic. It is also helpful when the majority of members share the same general opinion, or when quieter members are being pushed out of the discussion

\section{Body Language and Facilitation (cont.)}

The experienced facilitator will be careful not to send out nonverbal cues or body language that can be interpreted as negative by the receiving audience. For example, standing up leaning against a wall with your arms crossed tends to suggest a closed mind or inattentiveness. This type of body language subtly inhibits the free flow of communication.

Facilitators must also be keenly aware of the nonverbal cues given off by team members with whom they are working. Such cues can often be important indicators to test the pulse of the meeting.

\section{Group Process Techniques (cont.)} Response rounds Procedure:

Give the group members a task/question to work on individually.

Ask members to respond one at a time. People are allowed to pass. Record responses. Repeat until people run out of responses.

Summarize each round of responses if it seems appropriate. This is good to use if you expect a moderately high level of conflict to exist when the group discusses a particular topic. It is also helpful when the majority of members share the same general opinion, or when quieter members are being pushed out of the discussion

\section{Active Listening Skills}

-Maintain good eye contact

- Face the person or group head on

-Keep an open posture-don't cross arms

- Stay relaxed in your overall manner-this shows you are comfortable with the situation

- Be aware of body language and nonverbal behavior

-Listen for feeling as well as content-what is "between the lines" 


\section{PROGRAM PLANNER}

\section{Active Listening Skills (cont.)}

- Pause a few seconds before giving feedback or answering a question-take time to think about that was said

-Give the person time to correct an obvious mistake-this shows respect

- Show encouragement. Use simple gestures or phrases to show you are listening, e.g., say "Uh-huh;" nod your head

-Show support. Say, "That's good; anyone else having anything to add?"

\section{Active Listening Skills (cont.)}

•Don't "jump ahead" to complete the person's sentence-you are making an assumption that maybe incorrect

- Be aware of your own emotional response to what you are

hearing-it will affect how well you understand and can respond

- Focus your energy and attention on what is being said to you-not

on what you want to say next

\section{Dealing with Difficult participants}

\section{㴗}

Group Work:

Identify some behaviors of difficult participants and what you can do to intervene?

Plenary!

\section{Active Listening Skills (cont.)}

-Don't let the person ramble-try to help them come to their main point

-Don't turn an implication you've picked up in the conversation into a conclusion-proceed gradually

- Paraphrase or summarize what the person has said, and get agreement that you've understood completely

-Ask questions beginning with the words "what" and "how" (openended questions). Avoid questions that can be answered with a yes or no

\section{Facilitator moments}

Put on your facilitator's hat, then try to finish as many of these sentence as you can. When one group member seems to do most of the talking, I might... When an individual is silent for a long period of time, I could... When someone in the team "puts down" another member, I might... When a group seems to want to reach a decision, but appears unable to, I might... When someone comes late, I might... When group members are excessively polite and unwilling to confront each other's ideas, I might...

Take Home Message

Each mentor Tells the group - Her take home message! 


\section{FACILITATION SKILLS}

This 60-minute activity allows participants to learn about and practice a variety of facilitation skills that they will use as mentors in the program.

Time: 60 minutes

Materials: Flip chart, marker, chairs, koosh ball, rubber chicken, stretch ball, handouts

\section{Facilitator:}

\section{Objectives:}

- Participants learn different types of facilitation skills

- Participants understand how to apply these skills during safe space sessions

Process: The facilitator should prepare this session in advance by asking for at least 4 volunteers to be an audience during the session. The facilitator presents the 14 "Be's" of successful facilitation by acting out each one and having the participants guess the skill, then discuss or explain.

\section{The 14 "Be's" of Successful Facilitation}

1. Be exciting! Participants will be twice as emotional as you are. If you are excited, the participants will be twice as excited. If you are boring, the participants will be twice as bored. ACT: Facilitator appears bored while facilitating a session, e.g., facial expression is gloomy, maybe yawning and speaking in a low tone.

2. Be an elephant! An elephant has big ears and a small mouth: listen to what the participants say, let them speak. A good facilitator speaks 10 percent of the time. Ask questions, bounce questions from the participants back to the participants.

ACT: Facilitator talks throughout the session without giving a chance to any participant to say something.
3. Be neutral! Do not impose your values on the participants. The curriculum allows participants to share their values freely without the influence of the mentor's values.

ACT: Facilitator imposes her values on the participants by, for example, telling them that sex before marriage is a sin and they should all abstain from sexual activity.

4. Be prepared! Prepare by explaining the activities to others. Gather materials that you will need (be creative if you do not have the materials), and find out answers to questions you were not able to answer from the previous session.

ACT: Facilitator appears not ready during facilitation.

5. Be in eye contact!

Eye contact from all the participants means they are listening. If you are outside, make sure the sun is at the participants' backs and in your eyes.

ACT: Facilitator looks down, up, or sideways during facilitation and fidgets a lot.

6. Be honest! Answer all questions honestly. Do not feel bad if you do not know the answer to a question. Just say you do not know but you will do everything possible to find out. ACT: One participant asks the facilitator a question and she responds with false information, e.g., Can one get HIV by sharing plates, cups, or a handshake? Hmmm! I am not really sure, but yes one can get infected. 


\section{PROGRAM PLANNER}

\section{Be at the same level as the participants!}

-Sensitive discussions: If the participants laugh about the word "vagina," let them laugh about it. If they are allowed to laugh, they will be more likely to talk about it.

-Language: Do not use big words they will not know. Translate if necessary so all participants understand what you are talking about.

-Be aware of who your audience is and put yourself in their position (i.e., working with a group of vulnerable girls).

ACT: During facilitation, facilitator uses big words such as body anatomy, inflation, or surplus.

\section{Be consistent!}

It is easy to teach the best participants. Make sure you get participation from everyone. Ask quiet participants easy or simple questions to get everyone involved.

ACT: Facilitator points at the same participant for answers because she is the most active, and completely ignores those who are not participating.

\section{Be sensitive!}

Know how to handle sensitive issues, especially during discussions when participants open up and share their personal experience.

ACT: Facilitator introduces a game that allows participants to be comfortable discussing or sharing sensitive issues.

10. Be positive!

Keeping it positive maintains energy levels and makes a good environment for constructive criticism and learning. Give constructive criticism to participants in between two praise/positive points.

ACT: Facilitator should praise participants who answer correctly and also thank those who participate.

\section{Be heard!}

Volume, volume, volume! Make sure your voice is heard by all participants.

ACT: Facilitator speaks in a very low tone.

\section{Be timely!}

The curriculum allocates time for each activity, so if you do an activity for 2 hours that should be done in 20 minutes, your participants will get bored and you will miss carrying out other important activities.

\section{Be in control!}

-Participants will have so much fun they may forget they are learning. Quick energizers help control participants so everyone is paying attention to what you say.

-Remember the other "Be's" (especially 1, 5, 7, 8, $10,11,12$ ) to be in control effectively.

ACT: Facilitator introduces a quick energizer.

14. Be on track!

Do not let off-subject comments and questions from participants take you off the track of delivering the key messages of the activity. ACT: Participant asks a question that is not within the topic of discussion and tries to stray the group by focusing a bit on a different topic. Then facilitator gets the discussion on track by either answering the question or telling the group that it will be discussed in detail in another session. 


\section{TRAINING METHODOLOGIES}

\section{PART I: FACILITATION OF SAFE SPACES}

\section{Objective}

To build the capacity of mentors in facilitating the implementation of safe spaces and effectively delivering a curricula to the girls in the program

Time: 30 minutes total

Materials: Flip chart, marker, handouts, projector

Process: The facilitator explains the workshop objectives to the participants using PowerPoint and also writes the objectives on a flip chart in advance so they are stuck on the wall.

Time: 15 minutes

\section{Specific Objectives}

- Train mentors in understanding the concepts of the program.

- Equip mentors with comprehensive information about life skills, sexual and reproductive health, and financial management.

- Train mentors in facilitating a range of interactive methodologies to be used during the safe space sessions.

- Equip mentors with knowledge and skills to provide guidance and social support to girls participating in the safe space sessions.

Process: The trainer explains very briefly the experiential and highly interactive training the participants will be using during their weekly sessions with the girls as provided in the curriculum. This is a good time to invoke the old saying: "Tell me...I forget, Show me...I remember, Involve me...I understand." Explain that this training will be one of "involvement," of experiential learning.
Participatory teaching methods for building skills and influencing attitudes include the following:

- Group Discussions

- Brainstorming

- Demonstration and Guided Practice

- Role-play

- Small Groups

- Educational Games and Simulations

- Case Studies

- Storytelling

- Debates

The facilitator then divides the group into four smaller groups by having them count 1,2,3,4 and then clustering them according to their number. The groups are assigned tasks and given 15 minutes to prepare.

\section{Group 1: Role-play}

Instructions

- Decide as a group a situation to be role-played.

- Select role-players.

- Give instructions to role-players.

- Start role-play.

- Discuss what happened.

\section{Group 2: Games/simulations}

Instructions

- As a team, play a short game.

- It must be enjoyable and it does not matter who wins.

- Discuss briefly immediately after the game.

\section{Group 3: Debate}

Instructions

- Come up with a statement.

- Ask volunteers to give views.

- Ask 2-3 volunteers to present their views.

- Ask 2-3 volunteers with opposing views to present their views.

- Present the views. 


\section{Group 4: Storytelling}

Instructions

- Ask a volunteer in your group to tell a simple and clear story highlighting one or two points.

- The story must be relevant to the lives of participants.

- The story must be interesting.

Then briefly discuss the story.

PART II: PARTICIPATORY TEACHING

Objective

To introduce and familiarize mentors with the tools to be used during the program and provide a step-bystep guide to using the curriculum

Time: 60 minutes total

Materials: Flip chart, marker, curriculum (1 copy for each participant)

Process: Groups make presentations and then facilitator explains after each group presents

Time: 30 minutes

Process: The facilitator introduces the Health and Life Skills curriculum and takes the participants through the curriculum step by step.

Time: 30 minutes

Hand-out Material: Participatory Teaching Methods: Each of the teaching methods can be used to teach Life Skills. 


\section{TRAINING METHODOLOGIES (continued)}

Handout on participatory methods for teaching Life Skills

\begin{tabular}{|c|c|c|c|}
\hline Method & Description & Benefits & Process \\
\hline $\begin{array}{l}\text { Discussion (in } \\
\text { small or large } \\
\text { groups) }\end{array}$ & $\begin{array}{l}\text { The group examines } \\
\text { a problem or topic } \\
\text { of interest with } \\
\text { the goal of better } \\
\text { understanding of an } \\
\text { issue or skill, reaching } \\
\text { the best solution, or } \\
\text { developing new ideas } \\
\text { and directions for the } \\
\text { group. }\end{array}$ & $\begin{array}{l}\text { Provides opportunities for } \\
\text { participants to learn from one } \\
\text { another and practice turning to one } \\
\text { another in solving problems. } \\
\text { Enables participants to deepen } \\
\text { their understanding of the topic } \\
\text { and personalize their connection } \\
\text { to it. } \\
\text { Helps develop skills in listening, } \\
\text { assertiveness, and empathy. }\end{array}$ & $\begin{array}{l}\text { 1. Decide how to arrange seating } \\
\text { for discussion } \\
\text { 2. Identify the goal of the } \\
\text { discussion and communicate it } \\
\text { clearly } \\
\text { 3. Pose meaningful, open-ended } \\
\text { questions } \\
\text { 4. Keep track of discussion progress }\end{array}$ \\
\hline Brainstorming & $\begin{array}{l}\text { Participants actively } \\
\text { generate a broad } \\
\text { variety of ideas about } \\
\text { a particular topic or } \\
\text { question in a given, } \\
\text { often brief period of } \\
\text { time. Quantity of ideas } \\
\text { is the main objective } \\
\text { of brainstorming. } \\
\text { Evaluating or debating } \\
\text { the ideas occurs later. }\end{array}$ & $\begin{array}{l}\text { - Allows participants to generate } \\
\text { ideas quickly and spontaneously. } \\
\text { Helps participants use their } \\
\text { imagination and break loose from } \\
\text { fixed patterns of response. } \\
\text { Good discussion starter because } \\
\text { the group can creatively generate } \\
\text { ideas. } \\
\text { It is essential to evaluate the pros } \\
\text { and cons of each idea or rank ideas } \\
\text { according to certain criteria. }\end{array}$ & $\begin{array}{l}\text { 1. Designate a leader and a } \\
\text { recorder } \\
\text { 2. State the issue or problem and } \\
\text { ask for ideas } \\
\text { 3. Participants may suggest any } \\
\text { idea that comes to mind } \\
\text { 4. Do not discuss the ideas when } \\
\text { they are first suggested } \\
\text { 5. Record ideas in a place where } \\
\text { everyone can see them } \\
\text { 6. After brainstorming, review the } \\
\text { ideas and add, delete, categorize }\end{array}$ \\
\hline Role-play & $\begin{array}{l}\text { Role-play is an informal } \\
\text { dramatization in which } \\
\text { people act out a } \\
\text { suggested situation. }\end{array}$ & $\begin{array}{l}\text { Provides an excellent strategy } \\
\text { for practicing skills; experiencing } \\
\text { how one might handle a potential } \\
\text { situation in real life; increasing } \\
\text { empathy for others and their point } \\
\text { of view; and increasing insight into } \\
\text { one's own feelings. }\end{array}$ & $\begin{array}{l}\text { 1. Describe the situation to be role- } \\
\text { played } \\
\text { 2. Select role-players } \\
\text { 3. Give instructions to role-players } \\
\text { 4. Start the role-play } \\
\text { 5. Discuss what happened }\end{array}$ \\
\hline Small group & $\begin{array}{l}\text { For small group } \\
\text { work, a large group is } \\
\text { divided into smaller } \\
\text { groups of six or less } \\
\text { and given a short time } \\
\text { to accomplish a task, } \\
\text { carry out an action, or } \\
\text { discuss a specific topic, } \\
\text { problem, or question. }\end{array}$ & $\begin{array}{l}\text { - Useful when groups are large and } \\
\text { time is limited. } \\
\text { - } \quad \text { Maximizes participant input. } \\
\text { Lets participants get to know one } \\
\text { another better and increases the } \\
\text { likelihood that they will consider } \\
\text { how another person thinks. } \\
\text { - Helps participants hear and learn } \\
\text { from their peers. }\end{array}$ & $\begin{array}{l}\text { 1. State the purpose of discussion } \\
\text { and the amount of time available } \\
\text { 2. Form small groups } \\
\text { 3. Position seating so that members } \\
\text { can hear each other easily } \\
\text { 4. Ask group to appoint recorder } \\
\text { 5. At the end have recorders } \\
\text { describe the group's discussion }\end{array}$ \\
\hline $\begin{array}{l}\text { Games and } \\
\text { simulations }\end{array}$ & $\begin{array}{l}\text { Participants play } \\
\text { games as activities } \\
\text { that can be used for } \\
\text { teaching content, } \\
\text { critical thinking, } \\
\text { problem-solving, and } \\
\text { decision-making, } \\
\text { and for review and } \\
\text { reinforcement. } \\
\text { Simulations are } \\
\text { activities structured } \\
\text { to feel like the real } \\
\text { experience. }\end{array}$ & $\begin{array}{l}\text { Games and simulations promote } \\
\text { fun, active learning, and rich } \\
\text { discussion in the sessions as } \\
\text { participants work hard to prove } \\
\text { their points or earn points. } \\
\text { Games and simulations require } \\
\text { the combined use of knowledge, } \\
\text { attitudes, and skills and allow } \\
\text { participants to test out assumptions } \\
\text { and abilities in a relatively safe } \\
\text { environment. }\end{array}$ & $\begin{array}{l}\text { Games: } \\
\text { Remind participants that the activity } \\
\text { is meant to be enjoyable and that it } \\
\text { does not matter who wins } \\
\text { Simulations: } \\
\text { - Work best when they are brief } \\
\text { and discussed immediately } \\
\text { Participants should be asked to } \\
\text { imagine themselves in a situation } \\
\text { or should play a structured game } \\
\text { or activity to experience a feeling } \\
\text { that might come up in another } \\
\text { setting }\end{array}$ \\
\hline
\end{tabular}




\begin{tabular}{|c|c|c|c|}
\hline Storytelling & $\begin{array}{l}\text { The instructor or } \\
\text { participants tell or read } \\
\text { a story to a group. } \\
\text { Pictures, comics and } \\
\text { photo novels, filmstrips, } \\
\text { and slides can } \\
\text { supplement. } \\
\text { Participants are } \\
\text { encouraged to think } \\
\text { about and discuss } \\
\text { important (health- } \\
\text { related) points or } \\
\text { methods raised by the } \\
\text { story after it is told. }\end{array}$ & $\begin{array}{l}\text { - Can help participants think about } \\
\text { local problems and develop critical } \\
\text { thinking skills. } \\
\text { Participants can engage their } \\
\text { creative skills in helping to } \\
\text { write stories, or a group can } \\
\text { work interactively to tell stories. } \\
\text { Storytelling lends itself to drawing } \\
\text { analogies or making comparisons, } \\
\text { helping people to discover healthy } \\
\text { solutions. }\end{array}$ & $\begin{array}{l}\text { 1. Keep the story simple and clear. } \\
\text { Make one or two main points. } \\
\text { 2. Be sure the story (and pictures, } \\
\text { if included) relate to the lives of } \\
\text { the participants. } \\
\text { 3. Make the story dramatic enough } \\
\text { to be interesting. Try to include } \\
\text { situations of happiness, sadness, } \\
\text { excitement, courage, serious } \\
\text { thought, decisions, and problem- } \\
\text { solving behaviors. }\end{array}$ \\
\hline $\begin{array}{l}\text { Situation } \\
\text { analysis and } \\
\text { case studies }\end{array}$ & $\begin{array}{l}\text { Situation analysis } \\
\text { activities allow partic- } \\
\text { ipants to think about, } \\
\text { analyze, and discuss } \\
\text { situations they might } \\
\text { encounter. Case studies } \\
\text { are real-life stories that } \\
\text { describe in detail what } \\
\text { happened to a commu- } \\
\text { nity, family, school, or } \\
\text { individual. }\end{array}$ & $\begin{array}{l}\text { - Situation analysis allows } \\
\text { participants to explore problems } \\
\text { and dilemmas and safely test } \\
\text { solutions; it provides opportunities } \\
\text { to work together, share ideas, and } \\
\text { learn that people sometimes see } \\
\text { things differently. } \\
\text { Case studies are powerful catalysts } \\
\text { for thought and discussion. } \\
\text { - Participants consider the forces } \\
\text { that converge to make an } \\
\text { individual or group act in one way } \\
\text { or another, and then evaluate the } \\
\text { consequences. } \\
\text { By engaging in this thinking } \\
\text { process, participants can improve } \\
\text { their own decision-making skills. } \\
\text { Case studies can be tied to specific } \\
\text { activities to help participants } \\
\text { practice healthy responses before } \\
\text { they find themselves confronted } \\
\text { with a health risk. }\end{array}$ & $\begin{array}{l}\text { - Guiding questions are useful to } \\
\text { spur thinking and discussion } \\
\text { Facilitator must be skillful at } \\
\text { teasing out the key points } \\
\text { and step back and pose some } \\
\text { "bigger" overarching questions } \\
\text { - Situation analyses and case } \\
\text { studies need adequate time for } \\
\text { processing and creative thinking } \\
\text { - Teacher must act as the } \\
\text { facilitator and coach rather than } \\
\text { the sole source of "answers" and } \\
\text { knowledge }\end{array}$ \\
\hline
\end{tabular}




\section{THE MENTOR'S ROLE IN TEACHING AND LEARNING}

This activity, to be used during an introductory mentor training, includes exercises on the mentor's role and teaching style, and discussion of age-appropriate participatory learning techniques. Trainers find adolescents respond more favorably when training is participatory in nature. The traditional didactic format in which trainers lecture and answer students' questions has value, particularly in transmitting factual knowledge, such as how HIV is transmitted or how contraceptive methods work. However, training formats in which participants are invited to contribute their ideas and knowledge and build upon their own experience seem to generate more enthusiastic participation and greater retention of the subject matter.

\section{EXERCISE 1: THE TRAINER'S ROLE}

Expected results: Mentors reflect on their role as trainers for adolescent girls in their safe spaces Materials needed: Flip chart, marker, pen Instructions

- Ask the mentors to list the roles facilitators play during a workshop.

- Ask them to describe what each role entails.

- Compare their answers with these roles and tasks:

-Expert: The trainer transmits knowledge and skills, answers questions or promises to obtain information for participants later, clears up misconceptions.

- Socializing agent: The trainer strives to share values and ideals with trainees, for example, adolescents and adults should treat both female and male peers as equals and take responsibility for promoting healthy sexuality.

-Facilitator: The trainer helps learning take place on the basis of the participants' experience.

- Mention that trainers have the responsibility to facilitate different types of learning. These can be summarized as:

-Learning about subject matter; for example, what is gender?

-Learning about the relationship between the subject matter and real life; for example, how does gender affect adolescent boys' and girls' relationships?

-Learning how to apply knowledge learned; for example, how can adolescents use their gender sensitivity to recognize and avoid health risks? 


\section{EXERCISE 2: WHAT MAKES LEARNING ENJOYABLE?}

Expected results: Mentors are able to identify factors that made learning enjoyable

Materials needed: Sheets of paper, pencils or markers, grid on large sheet of paper posted at the front of the room (flip chart can be used).

\section{Instructions}

- Ask participants to draw two pictures: one showing how they learned during primary school and one showing how they learned during an enjoyable workshop later in life.

- Draw a grid on a flip chart as shown below, leaving the boxes under the second and third column headings blank.

- Invite some participants to show their pictures and tell what they represent; ask them to tell what they liked and did not like about the experiences they drew in their pictures.

- Fill in the grid by placing participants' statement about what they liked and did not like in the appropriate boxes.

- Summarize the results, mentioning points shown in the grid:

\begin{tabular}{|l|l|l|}
\hline Questions & Primary School Learning & Other Learning \\
\hline What is the learner's role? & $\begin{array}{l}\text { Passive; receive information; follow } \\
\text { instructions }\end{array}$ & $\begin{array}{l}\text { Active; participatory; responsibility } \\
\text { for learning; interdependent }\end{array}$ \\
\hline $\begin{array}{l}\text { What is the motivation for } \\
\text { learning? }\end{array}$ & $\begin{array}{l}\text { Good grades; don't get in trouble; } \\
\text { punishment; no immediate benefit seen; } \\
\text { external: society dictates }\end{array}$ & $\begin{array}{l}\text { Learning from within oneself; learn- } \\
\text { er sees immediate benefit; internal } \\
\text { motivation }\end{array}$ \\
\hline Who chooses content? & $\begin{array}{l}\text { Teacher or school board; no learner } \\
\text { choice }\end{array}$ & Own interests; life issues \\
\hline What is the method focus? & $\begin{array}{l}\text { Rote learning; one-way communication; } \\
\text { individual }\end{array}$ & $\begin{array}{l}\text { Experiential; teams or groups share } \\
\text { knowledge }\end{array}$ \\
\hline
\end{tabular}

\section{EXERCISE 3: GROUP WORK}

Expected results: Mentors brainstorm facilitation techniques suitable for particular age cohorts (e.g., 10-14 and 15-19) in groups.

\section{Instructions}

- Split mentors in two groups, one representing the 10-14-year age group and another representing the 15-19-year age group.

- Ask each group to brainstorm and list facilitation techniques suitable for the age group assigned to them.

- Bearing in mind what they have listed, groups should answer the following questions about how they can contribute to an enjoyable learning experience about adolescents in their safe spaces:

- What are the reasons adolescents are learning?

- What is your role as a mentor in their learning experience?

- How would you describe the learning environment in the safe space?

- How would you know that learning had occurred?

- Ask each group to prepare a "training tip" for the others based on their answers.

- Type out or write on paper cards the "training tips" and give them to all participants the next day as they prepare for the practical sessions. 


\section{TRAINING PRESENTATION: INTRODUCTION TO COUNSELING}

Mentors are often expected to do counseling as part of their work with girls. The objectives of this training are to describe the aims and principles of counseling, to teach mentors to employ counseling skills, and to provide the opportunity to practice the skills. Program staff should recognize that most mentors have faced (or are currently facing) similar challenges to girls in the program, and staff should adequately support mentors to respond to both girls' challenges and their own psychological well-being. Support can be provided during weekly and monthly check-ins, although some mentors will need more regular contact with supervisors or-in some cases-dedicated professional help. Programs should provide mentors with information about sources of psychosocial support for themselves and for program participants.

This presentation covers the attitudes of a good counselor, appropriate counseling environments, reflective listening, active listening, goal setting, and general counseling procedures.

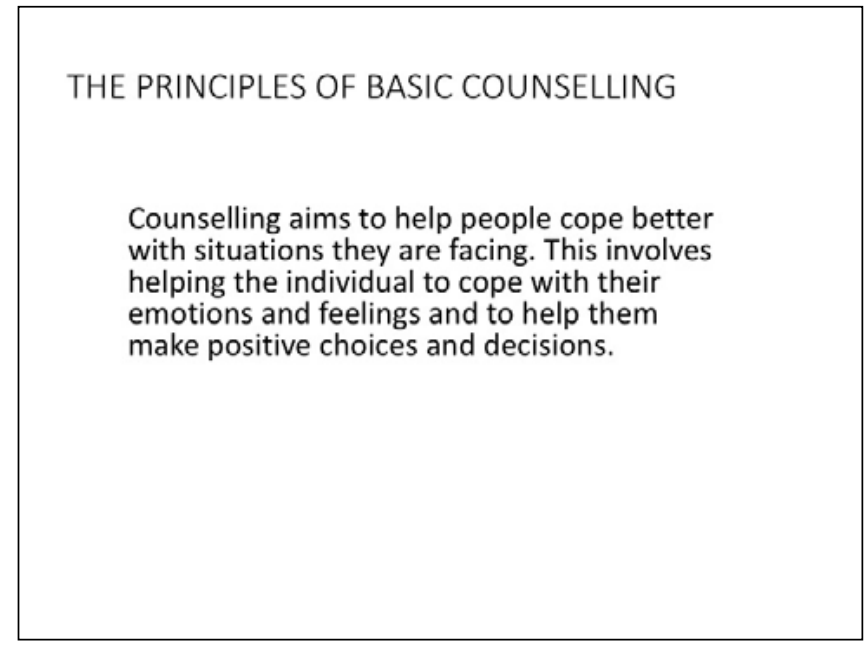

Slide 1

\section{THE PRINCIPLES OF BASIC COUNSELLING}

Doing this involves:

- Providing correct information;

- Helping the individual make informed decisions (autonomy);

- Helping the client to recognize and build on their strengths (empowerment);

- Helping the client develop a positive attitude; and,

- Maintaining a professional relationship.

\section{THE PRINCIPLES OF BASIC COUNSELLING}

\section{DOING THIS INVOLVES:}

-Establishing a trusting relationship;

- Helping the girl being counseled tell her story;

- Listening carefully;

- Respecting the girl being counseled;

- Being non-judgmental;

- Providing confidentiality;

\section{THE PRINCIPLES OF BASIC COUNSELLING}

IT DOES NOT INVOLVE:

- Making decisions for the girl being counseled;

- Judging, interrogating, blaming, preaching, lecturing or arguing;

- Making promises that you cannot keep;

- Allowing girls to become dependent on you.

Counseling is an approach for assisting people during and in the immediate aftermath of a pandemic, to reduce initial distress, and to encourage short and long-term adaptive functioning. 


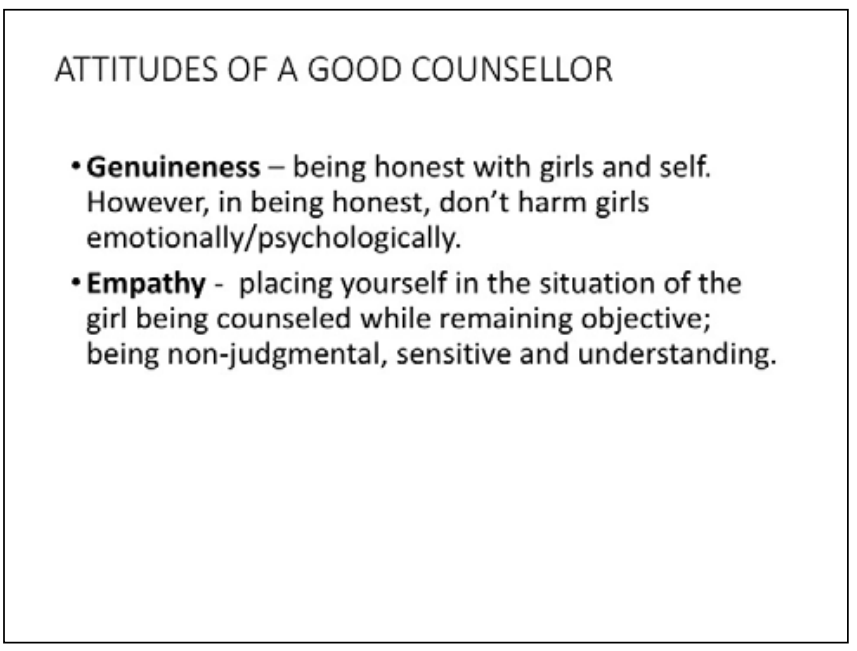

Slide 5

\section{ATTENDING SKILLS}

\section{Body Language and Emotional Presence}

- Be mindful of gestures made by yourself and that of the girl being counseled. Your body is a means of communication to the girl while the girl's body is a source of information.

- Be attentive to the girl being counseled both psychologically and physically

\section{ATTENDING SKILLS (cont.)}

\section{Open-ended and probing questions}

- Open-ended (who, what, where, when, how) and probing questions invite more than one- or twoword responses. These can be used to gather information, increase clarity, stimulate thinking, or create discussion.

\section{ATTITUDES OF A GOOD COUNSELLOR}

- Acceptance - value all aspects of the girl being counseled regardless of whether her situation is bad or good (unconditional positive regard); accept unconditionally regardless of gender, age, disability, economic status, race and the like.

Slide 6

\section{ATTENDING SKILLS (cont.)}

\section{Empathizing}

- Empathy means placing yourself in the situation of the girl being counseled while remaining objective. Empathizing requires the counselor to be nonjudgmental, sensitive and understanding.

\section{ATTENDING SKILLS (cont.)}

\section{Active listening}

- Listen to the girl being counseled carefully instead of thinking about what you are going to say next.

- Sit comfortably. Avoid distracting movements. Look directly at the girl when she speaks, not at your papers or out the window.

- Every now and then repeat in your words what you have heard. This is called "paraphrasing." Then both you and the girl being counseled know whether you have understood. 


\section{PRESENTATION: INTRODUCTION TO COUNSELING (continued)}

\section{ATTENDING SKILLS (cont.)}

\section{Summarize}

- This can be done at the beginning, ongoing and at the end of the session, so that you both can agree on what was discussed and what you both will do after leaving.

- Highlight and clarify issues so that the girl being counseled can see the broader picture.

- Pinpoint possible solutions that were discussed.

-Ask the girl being counseled how she feels about what has been discussed.

\section{COUNSELLING PROCEDURE}

1. Create rapport

- Welcome and offer a seat

- Introductions

- Assure girl being counseled of confidentiality, time limits, responsibilities

- Counseling procedure/type: Individual or Group

2. Ask girl being counseled to share what she has come for

3. Use counseling skills - towards end: goal setting and summarizing

\section{SUB-SKILLS OF ATTENDING}

Are also referred to by the acronym SOLER

-S - Sit squarely: Face the girl being counseled, unless this is considered rude (in some cultures)

- O-Open posture: Avoid crossed arms and leaning backwards.

- $\mathrm{L}$ - Lean toward the girl being counseled slightly: shows interest in her issues.

-E - Direct Eye contact with the girl being counseled: This brings out truth.

- R- Be of a Relaxed mood as a counsellor

\section{PRACTICAL WORK}

In pairs come up with a counseling case and role play the following counseling skills

1. Empathizing and listening skills

2. Open ended and probing skills

3. Paraphrasing, reflecting, restating skills

4. Goal setting and summarizing skills 


\section{PROGRAM PLANNER}

\section{MENTOR TRAINING SESSION ON GENDER-BASED VIOLENCE AND HUMAN RIGHTS}

This 1.5-hour training session covers key concepts and basic issues underpinning gender-based violence (GBV). Its aim is to increase participants' ability to discuss key concepts in ways that can be understood by the community; identify the relationship between abuse of power and GBV; understand that the term "violence" in the context of GBV means using some type of force, which may or may not include physical force; understand the meaning of "informed consent" and its relationship to GBV; and understand the relationship between human rights and GBV.

Gender-Based Violence and Human Rights

Length: 1.5 hours

\section{Training Objectives:}

- To help participants understand and describe the key concepts and basic issues underpinning all forms of GBV

- To increase participants' abilities to discuss the key concepts in ways that can be well understood by the community

- Identify the relationship between abuse of power and GBV

- Understand that the term "violence" in the context of GBV means using some type of force, which may or may not include physical force

- Understand the meaning of "informed consent" and its relationship to GBV

- Understand the relationship between human rights and GBV

\section{Overview:}

This session explores the meaning of three important concepts behind the term GBV. The three concepts are combined in this session, but they are introduced and discussed one by one, to continue building participants' understanding carefully, step by step. Two case examples are used for group discussion to reinforce learning about these concepts.

Materials: Flip charts, markers

Session type: Discussion, group activities

\section{Procedure:}

Power (10 minutes)

1. On the flip chart, write the word POWER.

2. Ask the group "what gives someone power?" and write their answers on the flip chart.

3. Discuss various types of power. Ask for some examples (without names) of people who have power in the world, in the community.

4. Explain that GBV is about abusing power, whether the power is real or perceived; the victim of abuse believes the power is real.

5. Tape the power flip chart to the wall nearby, where it can be seen and referred to later in the session.

Violence/Use of Force (10 minutes)

1. On a new blank flip chart, write the word VIOLENCE.

2. Ask each participant to take a piece of paper and write two words or phrases to describe what we mean by "violence" when we are talking about GBV. This is an individual activity, not group work. Allow a few moments for everyone to write their two words.

3. Go around the room, one by one, asking each person to give one word/phrase they wrote. Put the word on the flip chart. Keep going round the room until you have everyone's word on the flip chart. This should be a quick exercise.

4. Participants usually give a combination of examples of types of violence as well as some definitions of the word "violence." 


\section{MENTOR TRAINING SESSION ON GENDER-BASED VIOLENCE AND HUMAN RIGHTS \\ (continued)}

5. Stand back from the flip chart and facilitate a short discussion to call out key discussion points, cross out any word or phrases that participants agree don't belong on the list.

- At the top of the flip chart, write "use of force" next to "violence." Should look like this: VIOLENCE/USE OF FORCE.

- Summarize by explaining that violence in this context involves the use of some type of force, real and implied-and this is a key element in defining what we mean when we say GBV.

- Tape the violence flip chart on the wall near the power flip chart, where they both can be seen and referred to later in the session.

Informed Consent (5 minutes)

1. On the new blank flip chart, write the word CONSENT.

2. Ask participants what consent means to them. Write their responses on the flip chart. Discuss their responses and be sure to stress two necessary components of consent: that it's "informed" and "voluntary."

3. Summarize the session by pointing to all three flip charts: Power, violence/use of force, consent. Quickly review the main points of each of these key concepts. Read the following example to participants. Then ask each question and discuss:

"In a very traditional and patriarchal family, the father of a 16-year-old girl tells her that he has arranged for her to marry a certain man. The girl doesn't know the man very well, he is much older than she is, but she agrees to the marriage."
- Do you think this kind of situation could happen?

- Did she give her informed consent to this marriage?

- Was there any force used in this incident?

- Who is more powerful in this example: father or daughter?

- What kind of power does this father have?

4. What kind of power does the daughter have?

5. How does power relate to choice in this example?

\section{Human Rights}

\section{Overview:}

All acts of GBV are a violation of fundamental human rights. The session briefly explores human rights in the context of GBV, which is another basic concept or principle that will lead participants to a clear understanding of the meaning of GBV.

Objective: To understand the relationship between human rights and GBV

Materials: Flip charts, markers

Session type: Discussion

\section{Procedure:}

1. Write HUMAN RIGHTS on the flip chart. Ask participants who has human rights and write their responses on the flip chart. Discuss the concept that everyone has human rights. Ask the respondents who or what grants human rights. Discuss the concept that nobody has to give these rights to you because you have them automatically from birth.

2. Ask participants for examples of human rights and write their responses on the flip chart. 


\section{Key Discussion Points:}

1. Human rights are universal, inalienable, indivisible, interconnected, and interdependent.

2. Everyone is entitled to all the rights and freedoms, without distinction of any kind, such as race, color, sex, language, religion, political or other opinion, etc.

3. Prevention of and response to GBV is directly linked to the protection of human rights.

4. Acts of GBV violate a number of human rights principles enshrined in international instruments. These include:

- Right to life, liberty, and security of person

- Right to the highest standard of physical and mental health

- Right to freedom from torture, rape, or cruel, inhumane, or degrading treatment or punishment

- Right to freedom of opinion and expression, to education, to social security, and to personal development

\section{Concluding the Session:}

The facilitator should mention that:

1. Perpetrators of GBV can have "real or "perceived" power (e.g., Social: Peer pressure and bullying; Gender-based: Males are usually in a more powerful position than females).

2. Power is directly related to choice. The more power one has, the more choices. The less power one has, the fewer choices are available.
3. GBV involves the abuse of power. In unequal power relationships individuals may be exploited or abused.

4. Do all people with power abuse their power? NO.

5. "Force" might be physical, emotional, social, or economic in nature.

6. Consent means saying "YES" agreeing to something. Informed consent means making an informed choice freely and voluntarily by persons in an equal power relationship.

7. Children (under age 18) are deemed unable to give informed consent for acts such as marriage, sexual relations, etc. 


\section{MENTOR TRAINING SESSION ON WORKING WITH GIRLS WITH DISABILITIES}

\section{Objectives}

- Create awareness on disability, rights, and issues that girls with disabilities face

- Build participants' skills on identifying disability and working with girls with disabilities in safe spaces

\section{Steps}

\section{Introduction}

Introduce the session on disability and ask volunteers for any related or appropriate energizer

\section{Group Work}

1. Put participants in groups; ideally create four groups

2. Let them discuss the following:

- What do you understand by the word "disability"?

- What types of disabilities do you know of, have you seen or heard of?

- What challenges do we face or are we likely to face with girls with disabilities in our safe spaces?

- How can we address them?

- How do you perceive persons with disabilities?

- Do a plenary once the group discussions have been concluded. Ask questions and clarify where need be.

\section{Presentation}

- Read "Sarah's story" to your participants and then, based on the story, discuss and brainstorm about discrimination against girls with disabilities and how it can be overcome.

- Conclude by asking participants to share what they have learned and also if they know of any female role models with disabilities.

\section{Sarah's Story: Discrimination Against Girls with Disabilities}

Sarah is a girl in the safe space program. She regularly attends meetings and is eager to learn. Her challenge is that her speech is impaired and each time she speaks during the session, her friends laugh at her. This has disturbed her participation and attendance in the safe space.

What is discrimination? When someone is treated unfairly as a result of stigma, treating someone differently because of perceptions or prejudices about them.

\section{How is discrimination shown in Sarah's story?}

- Would anyone want to share different stories of what they have experienced in their safe space that demonstrates discrimination against girls with disabilities?

- What are the possible effects of stigma and discrimination?

Possible answers include: Leads to absenteeism, leads to low self-esteem, afraid to associate with others, or isolation.

- How can mentors deal with discrimination against girls with disabilities in their safe spaces? 


\section{REFRESHER TRAINING-OF-TRAINERS AGENDA}

One training usually isn't enough for mentors to feel confident in their ability to remember key concepts and deliver content. Regular meetings are important for reflection, discussion, and opportunities to practice facilitation. It can also be helpful to bring mentors together for a streamlined version of a training after they have a few months of experience being a mentor.

The following is a sample agenda from a 4.5-day refresher training with 35 mentor participants. It details a refresher training that aims to: get feedback from mentors on their experience delivering information on Life Skills, Sexual and Reproductive Health, and Financial Education curricula; review and enhance mentors' skills in interactive facilitation methods; allow mentors to acquire accurate information on life skills, sexual and reproductive health, and financial management; and allow mentors to gain more experience in offering guidance and social support to girls during safe space sessions.

Training period:

Date:

Site:

Participants (Mentors):

Venue:

Facilitators: One Program Coordinator, Two Site Coordinators

\section{Objectives:}

The overall objective of the refresher training of trainers' workshop for the safe space mentors is for continued support and capacity building of mentors in facilitating the implementation of safe spaces and effectively delivering health and life skills and financial education curricula to the girls in the program.

The specific objectives of the workshop are:

- To get feedback from mentors on their experience delivering the curricula.

- To review and enhance mentors' skills in facilitating a range of interactive methodologies during the safe space sessions.

- For mentors to acquire accurate information on life skills, sexual and reproductive health, and financial management.

- For mentors to gain more experience in offering guidance and social support to girls during safe space sessions. 


\section{REFRESHER TRAINING-OF-TRAINERS AGENDA (continued)}

Day 1

\begin{tabular}{|c|c|c|c|}
\hline Time & Session & Objectives & Facilitator \\
\hline $16.00-16.10$ & $\begin{array}{l}\text { Welcome, participant } \\
\text { introductions/icebreaker }\end{array}$ & & \\
\hline $16.10-16.55$ & Mentor Survey Tool & - To assess level of participants' knowledge & \\
\hline $16.55-17.05$ & Objectives & - To clarify workshop objectives & \\
\hline $17.05-17.20$ & Ground rules & - $\quad$ To agree on the ground rules for the workshop & \\
\hline $17.20-17.35$ & Participants' expectations & - To share expectations for the refresher training & \\
\hline $17.35-18.00$ & Presentation & $\begin{array}{l}\text { - } \quad \text { To refresh mentors on the program } \\
\text { - To refresh mentors on the program objectives } \\
\text { To refresh mentors on the evaluation component } \\
\text { of the program }\end{array}$ & \\
\hline $18.00-19.30$ & Feedback Session & $\begin{array}{ll}\text { - } & \text { To get feedback from mentors on their } \\
\text { experience in implementing safe spaces } \\
\text { - } \quad \text { Share challenges } \\
\text { - Brainstorm possible solutions to challenges } \\
\text { encountered }\end{array}$ & \\
\hline $19: 30$ & & WRAP UP, DINNER BREAK & \\
\hline
\end{tabular}

Day 2

\begin{tabular}{|c|c|c|c|}
\hline Time & Session & Objectives & Facilitator \\
\hline $8.00-8.15$ & Energizer/Housekeeping & $\begin{array}{l}\text { To provide participants with the experience of } \\
\text { energizers from the Energizer Manual/other } \\
\text { suggested energizers }\end{array}$ & \\
\hline $8.15-8.30$ & Feedback on Day 1 & - To provide an ongoing evaluation of the workshop & \\
\hline $8.30-10.30$ & $\begin{array}{l}\text { Information Session } \\
\text { Skills building }\end{array}$ & $\begin{array}{l}\text { - Participants are refreshed on key facilitation skills } \\
\text { - } \quad \text { Participants understand how to apply different } \\
\text { skills in facilitating safe spaces } \\
\text { Introduce techniques for successfully engaging } \\
\text { the girls in the session } \\
\text { Brainstorm on facilitation techniques suitable for } \\
\text { particular age cohorts in smaller groups }\end{array}$ & \\
\hline $10.30-11.00$ & & TEA BREAK & \\
\hline $11.00-13.00$ & $\begin{array}{l}\text { Information Session } \\
\text { Values clarification of sexual } \\
\text { and reproductive health } \\
(\mathrm{SRH}) \text { for adolescent girls }\end{array}$ & $\begin{array}{l}\text { - To address mentors' knowledge, attitudes, and } \\
\text { behaviors regarding SRH for adolescent girls } \\
\text { - To provide an overview of the reality on the } \\
\text { ground for adolescent girls and SRH } \\
\text { - To enhance awareness of adolescent girls' SRH } \\
\text { rights in [Country] }\end{array}$ & \\
\hline $13.00-14.00$ & & LUNCH BREAK & \\
\hline
\end{tabular}




\begin{tabular}{|c|c|c|}
\hline 14.00-16.00 & $\begin{array}{l}\text { Information Session } \\
\text { Sexually transmitted } \\
\text { infections (STIs) and safer } \\
\text { sex }\end{array}$ & $\begin{array}{l}\text { By the end of this session the participants should } \\
\text { be able to: } \\
\text { - } \quad \text { Deplain the meaning of STIs } \\
\text { - } \quad \text { Explain the relationship between STIS and HIV } \\
\text { infection } \\
\text { - List at least four misconceptions about STIS } \\
\text { - Explain the consequences of STIs if they are not } \\
\text { treated }\end{array}$ \\
\hline $16.00-16.30$ & & TEA BREAK \\
\hline $16.30-17.30$ & $\begin{array}{l}\text { Refresher to the "Anchor, } \\
\text { Add, Apply, Away" } \\
\text { approach curriculum (focus } \\
\text { on techniques to successfully } \\
\text { engage the different age } \\
\text { cohorts) } \\
\text { Assignment session: } \\
\text { Participants are assigned } \\
\text { topics from the Curriculum }\end{array}$ & $\begin{array}{l}\text { - Participants understand the four A's and learn } \\
\text { how to apply them when delivering sessions in the } \\
\text { curriculum } \\
\text { Participants are divided into two groups by age } \\
\text { (10-14 and 15-19) and each group is designated a } \\
\text { session to prepare and present } \\
\text { The presentations should focus on applying } \\
\text { techniques on how to successfully engage the } \\
\text { different age cohorts during safe space sessions }\end{array}$ \\
\hline 17.30-18.30 & $\begin{array}{l}\text { Preparatory sessions for } \\
\text { group presentations }\end{array}$ & $\begin{array}{l}\text { - Participants go into their groups to prepare for } \\
\text { presentations. }\end{array}$ \\
\hline 18.30-19.30 & $\begin{array}{l}\text { Team 1: Age 10-14 group } \\
\text { (Pick session from } \\
\text { curriculum) } \\
\text { Practical session group } \\
\text { feedback }\end{array}$ & $\begin{array}{l}\text { - Participants practice facilitation skills and use of } \\
\text { techniques that successfully engage the 10-14 age } \\
\text { groups } \\
\text { Participants identify facilitation skills used to } \\
\text { effectively facilitate } \\
\text { - Participants discuss challenges encountered } \\
\text { during facilitation }\end{array}$ \\
\hline 19.30 & \multicolumn{2}{|r|}{ WRAP UP, DINNER BREAK } \\
\hline
\end{tabular}

Day 3

\begin{tabular}{|c|c|c|c|}
\hline Time & Session & Objectives & Facilitator \\
\hline $8.00-8.15$ & Energizer/Housekeeping & $\begin{array}{l}\text { To provide participants with the experience of } \\
\text { energizers from the Energizer Manual/other } \\
\text { suggested energizers }\end{array}$ & \\
\hline $8.15-8.30$ & Feedback on Day 2 & - To provide an ongoing evaluation of the workshop & \\
\hline $8.30-10.30$ & $\begin{array}{l}\text { Discussion Session } \\
\text { Reviewing feedback } \\
\text { and Financial Education } \\
\text { experiences in safe } \\
\text { spaces; obstacles and } \\
\text { positive discoveries }\end{array}$ & $\begin{array}{l}\text { Participants share and discuss challenges and } \\
\text { positive experiences in facilitating Financial } \\
\text { Education in safe spaces }\end{array}$ & \\
\hline $10.30-11.00$ & & TEA BREAK & \\
\hline $11.00-13.00$ & $\begin{array}{l}\text { Training topic: Exploring } \\
\text { girls' options for optimizing } \\
\text { savings and account usage } \\
\text { through safe spaces (If } \\
\text { savings groups are part of } \\
\text { program) }\end{array}$ & $\begin{array}{l}\text { - Participants acquire practical skills in supporting } \\
\text { savings practices in safe spaces } \\
\text { Participants explore options for engaging girls in } \\
\text { account-usage strategies, including regular } \\
\text { messaging }\end{array}$ & \\
\hline $13.00-14.00$ & & LUNCH BREAK & \\
\hline
\end{tabular}




\section{REFRESHER TRAINING-OF-TRAINERS AGENDA (continued)}

\begin{tabular}{|c|c|c|}
\hline $14.00-16.00$ & $\begin{array}{l}\text { Training Topic } \\
\text { Role-play resolving conflicts } \\
\text { Assignment session: } \\
\text { Participants are assigned } \\
\text { topics from the curriculum }\end{array}$ & $\begin{array}{l}\text { - Participants acquire skills in using role-play to } \\
\text { increase girls' understanding of money } \\
\text { The presentation will focus on the use of the } 4 \mathrm{~A}^{\prime} \mathrm{s} \\
\text { to increase facilitation skills and familiarize } \\
\text { participants with topics in the curriculum }\end{array}$ \\
\hline $16.00-16.30$ & \multicolumn{2}{|r|}{ TEA BREAK } \\
\hline $16.30-18.30$ & $\begin{array}{l}\text { Preparatory session for } \\
\text { group presentation }\end{array}$ & $\begin{array}{l}\text { Participants go into their groups to prepare for } \\
\text { presentations }\end{array}$ \\
\hline $18.30-19.30$ & $\begin{array}{l}\text { Practical session group } \\
\text { feedback }\end{array}$ & $\begin{array}{l}\text { Participants identify facilitation skills used to effectively } \\
\text { facilitate }\end{array}$ \\
\hline 19.30 & \multicolumn{2}{|r|}{ WRAP UP, DINNER BREAK } \\
\hline
\end{tabular}

Day 4

\begin{tabular}{|c|c|c|c|}
\hline Time & Session & Objectives & Facilitator \\
\hline $8.00-8.15$ & Energizer/Housekeeping & $\begin{array}{l}\text { - To provide participants with the experience of } \\
\text { energizers from the Energizer Manual/other } \\
\text { suggested energizers }\end{array}$ & \\
\hline $8.15-8.30$ & Feedback on Day 3 & - To provide an ongoing evaluation of the workshop & \\
\hline $\begin{array}{l}8.30-9.00 \\
9.00-10.30\end{array}$ & $\begin{array}{l}\text { Savings Account } \\
\text { Health Voucher Review }\end{array}$ & $\begin{array}{l}\text { - Go over any key issues on the savings account (if } \\
\text { this is part of your program) } \\
\text { Go over any key issues on the health voucher (if } \\
\text { this is part of your program) }\end{array}$ & \\
\hline $10.30-11.00$ & & TEA BREAK & \\
\hline $11.00-13.00$ & $\begin{array}{l}\text { Information Session } \\
\text { Working with girls with } \\
\text { disabilities }\end{array}$ & $\begin{array}{l}\text { - } \quad \text { dentify and address disabilities in Safe Spaces } \\
\text { groups } \\
\text { Build participants' skills working with girls with } \\
\text { disabilities }\end{array}$ & \\
\hline $13.00-14.00$ & & LUNCH & \\
\hline $14.00-16.00$ & $\begin{array}{l}\text { Information Session } \\
\text { Rape and Gender-based } \\
\text { Violence }\end{array}$ & $\begin{array}{l}\text { - Participants understand rape, date rape, and incest } \\
\text { - } \quad \text { Participants understand ways to prevent and deal } \\
\text { with sexual abuse and rape } \\
\text { - Participants learn about SRH rights }\end{array}$ & \\
\hline $16.00-16.30$ & & TEA BREAK & \\
\hline $16.30-18.30$ & $\begin{array}{l}\text { Information Session } \\
\text { Provision of support and } \\
\text { referral }\end{array}$ & $\begin{array}{l}\text { - To understand key aspects in psychosocial support } \\
\text { - To identify warning signs of the need for } \\
\text { psychosocial support and referral } \\
\text { - To identify community systems and structures for } \\
\text { support and referral } \\
\text { - To understand the roles that the different } \\
\text { community systems identified can play in offering } \\
\text { support }\end{array}$ & \\
\hline $18.30-19.30$ & $\begin{array}{l}\text { Team 2: 15-19-year age } \\
\text { group (pick session from } \\
\text { curriculum) } \\
\text { Practical session group } \\
\text { feedback }\end{array}$ & $\begin{array}{l}\text { - Participants practice facilitation skills and use of } \\
\text { techniques that successfully engage the 10-14- } \\
\text { year age groups } \\
\text { Participants identify facilitation skills used to } \\
\text { effectively facilitate } \\
\text { - Participants discuss challenges encountered } \\
\text { during facilitation }\end{array}$ & \\
\hline 19.30 & \multicolumn{2}{|r|}{ WRAP UP, DINNER BREAK } & \\
\hline
\end{tabular}


Day 5

\begin{tabular}{|c|c|c|c|}
\hline Time & Session & Objectives & Facilitator \\
\hline $8.00-8.15$ & $\begin{array}{l}\text { Energizer/ } \\
\text { Housekeeping }\end{array}$ & $\begin{array}{l}\text { - To provide participants with the experience of } \\
\text { energizers from the Energizer Manual/other suggested } \\
\text { energizers }\end{array}$ & \\
\hline $8.15-8.30$ & Feedback on Day 4 & - $\quad$ To provide an ongoing evaluation of the workshop & \\
\hline $8.30-10.30$ & $\begin{array}{l}\text { Attendance App (if } \\
\text { using app-based } \\
\text { method to keep } \\
\text { attendance) }\end{array}$ & $\begin{array}{l}\text { - } \quad \text { Review application } \\
\text { - } \quad \text { Teach mentors how to download a new form } \\
\text { - } \quad \text { Review chiteria, including at what point a girl is } \\
\text { marked present at the Safe Space meeting depending } \\
\text { on time of arrival } \\
\text { - Taking attendance at makeup sessions }\end{array}$ & \\
\hline $10.30-11.00$ & \multicolumn{2}{|r|}{ TEA BREAK } & \\
\hline $11.00-13.00$ & Home visits & $\begin{array}{l}\text { - Participants understand the importance of conducting } \\
\text { - } \quad \text { Participants understand how to structure home visits } \\
\text { - Participants understand how to report on home visits } \\
\text { - Participants share challenges and brainstorm on } \\
\quad \text { solutions }\end{array}$ & \\
\hline $13.00-14.00$ & \multicolumn{2}{|r|}{ LUNCH BREAK } & \\
\hline $14.00-15.00$ & $\begin{array}{l}\text { Monitoring and } \\
\text { evaluation }\end{array}$ & $\begin{array}{ll}\text { - } & \text { Review of monitoring and evaluation tools } \\
\text { - } & \text { Registers/Attendance } \\
\text { - } & \text { Reports } \\
\text { - } & \text { Documentans } \\
\text { - } & \text { Curriculum cycle (what to do when you get through } \\
& \text { the first cycle of the curriculum) }\end{array}$ & \\
\hline $15.00-16.30$ & $\begin{array}{l}\text { Evaluation and next } \\
\text { steps }\end{array}$ & $\begin{array}{l}\text { - To summarize the achievements of the workshop } \\
\text { - To explain what is expected of the mentors going } \\
\text { forward }\end{array}$ & \\
\hline $16.30-17.00$ & $\begin{array}{l}\text { Post-test } \\
\text { questionnaire }\end{array}$ & $\begin{array}{l}\text { - To measure the levels of knowledge gained by } \\
\text { participants from participating in the training }\end{array}$ & \\
\hline 17.00 & & CLOSING CEREMONY & \\
\hline
\end{tabular}




\section{PROGRAM PLANNER}

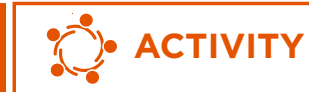

\section{MENTOR REFRESHER TRAINING}

This 1.5-hour session is intended to be used during mentor refresher trainings to review positive experiences and challenges faced during facilitation and to discuss experiences with Financial Education, which is a key part of many programs for girls. The language can be modified to be applicable to lessons on other topics.

Duration: 2 hours

Topic: Reviewing feedback and Financial Education experiences in safe spaces-Obstacles and positive discoveries

\section{Session Objectives:}

- Participants share and discuss challenges and positive experiences in facilitating Financial Education in safe spaces

- Share market research recommendations on improving Financial Education

Methodology: Group discussion

\section{Material:}

- Flip chart

- Markers

- A hand-drawn picture of a mentor on a journey, either walking or riding a bicycle, showing distance covered as well as the road ahead. Beside the picture should be a nice greenery scene, and on the other side, possible obstacles like stones, stumbling blocks, etc.

\section{Procedure:}

1. Divide participants in groups of 7 to make 5 groups (varies depending on overall group size)

2. Each group should choose a note taker and a presenter

3. Display the hand-drawn picture on the wall and draw participants' attention to it

4. Ask each group to discuss the following statements and questions based on the picture:

- This is a mentor in the program-just like you -who has been facilitating Financial Education (FE) in safe spaces since the program was launched.
- In her journey of facilitating FE, she has met challenges, achievements, obstacles, and positive discoveries

- What would you say about her knowledge and understanding of Financial Education before she started facilitating FE in safe spaces?

- What challenges and obstacles has she faced in facilitating FE during safe spaces and how has she dealt with them?

- What achievements and what positive discoveries has she experienced as a facilitator and mentor in FE?

- Which topics have been more challenging or difficult to facilitate?

- Which FE topics have been more popular and more appealing to girls in safe spaces?

- How have girls responded to learning about money and money management in safe spaces?

- Share at least two success stories (per group) in FE.

- How can this mentor be helped in delivering FE better in safe spaces?

Group Discussion: 20 minutes

Group Presentations: 50 minutes

Wrap Up and Conclusion by Facilitator: 20 minutes 


\section{CANDLE-LIGHTING CEREMONY: CONCLUSION OF THE MENTOR TRAINING}

This reflective session can be used to officially close a mentor training.

1. Ask everyone to stand in a circle.

2. Pass out candles to everyone.

3. Explain that during this training, we have learned about ourselves and have learned from each other.

- Each of us has shared something special with the group.

- As mentors you will learn about yourself and learn from the girls.

- You will share a lot of yourself, but you will also gain a lot from the girls in your safespace group.

4. Read out the following statement: "A candle loses nothing by lighting another candle."

5. Ask the group the meaning of the statement. Discuss.

6. Turn off the lights.
7. Summarize the meaning of the statement while lighting your candle.

- When you share your light, your passion, your friendship with your group members, you will still shine just as bright. You won't lose anything, you will only gain from the experience.

- When sharing your light with girls, one-byone, each girl is making the world brighter.

- Then turn and pass your candle flame to the person next to you, then that person will turn and pass the flame to the next person, and so forth around the room.

8. Continue to point out how the room becomes brighter by this sharing, but that no one has lost anything by contributing her flame to friends.

9. When all candles are lit, ask if anyone has anything more to say.

10. Close with an appropriate speech, then blow out all of the candles. 


\section{BALIKA: ENHANCING MENTOR CAPACITY WITH WEEKLY MOCK DEMONSTRATION SESSIONS}

\author{
BALIKA (Bangladeshi Association \\ for Life Skills, Income, and \\ Knowledge for Adolescents) tested \\ three skills-building approaches \\ to empower girls with the aim \\ of delaying marriage for around \\ 9,000 girls aged 12-18 years in \\ three districts in southwestern \\ Bangladesh.
}

The intervention provided education support, life skills training, and livelihoods training through weekly girl groups led by female mentors. Given mentors' role in facilitating girl group sessions, it was essential to provide mentors with training and ongoing support. At the program's outset, BALIKA mentors attended a comprehensive four-day residential training on their role as mentors, basic life skills, facilitation skills, and computer and tablet usage. Depending on the type of intervention they were managing, some mentors attended an additional threeday residential training on gender rights and awareness and/or training on livelihoods. At the one-year mark, mentors attended a refresher training.

During program implementation, BALIKA used a tool called "mock demonstration sessions" where, every week, 7-8 mentors from neighboring subdistricts met with their managing supervisor at the program offices to practice facilitating their sessions for the following week. These small group meetings helped to improve the session quality and mentors' facilitation skills, as well as provide mentors regular peer and supervisory feedback to deliver BALIKA topics more effectively. The meetings served as an ongoing assessment of mentor performance and a way for the program team to identify and invite leaders to represent the group at local and national events. The weekly gatherings also gave mentors space and time to get to know each other better, support one another, learn from each other how to deal with field implementation challenges, and raise issues with a collective voice.

With the scale-up of BALIKA, local experts such as health providers and IT service providers use weekly mock demonstration sessions to provide specialized training on relevant program areas. The BALIKA team realized the weekly meeting model works well when the mentors live close to each other and the program office. If mentors need to travel long distances to meet up each week, the model may not be as effective and may need to be adapted.

For more information: Delaying child marriage through community-based skills-development programs for girls: Results from a randomized controlled study in rural Bangladesh. 2016. https://knowledgecommons.popcouncil.org/departments_ sbsr-pgy/557/. 


\section{CHAPTER 3}

\section{Forming community-based groups and delivering core content}

$\begin{array}{llr}\text { ACTIVITY } & \text { Introductory Exercises and Icebreakers } & \text { Page } 81 \\ \text { ACTIVITY } & \text { Group Formation } & 82 \\ \text { ACTIVITY } & \text { Set Ground Rules } & 84 \\ \text { GUIDE } & \text { Facilitation: Teaching Tips for Mentors } & 86 \\ \text { GUIDE } & \text { Talking About Sensitive Issues: Teaching Tips } & 89 \\ \text { GUIDE } & \text { Engaging Mentees and Parents } & 91 \\ \text { TOOL } & \text { Session Planning } & 93 \\ \text { ACTIVITY } & \text { Games and Participatory Exercises } & 94 \\ \text { CASE STUDY } & \text { Adolescent Girls Initiative-Kenya: Program Adaptation } & 102 \\ & \text { for Low-Literacy Mentors }\end{array}$




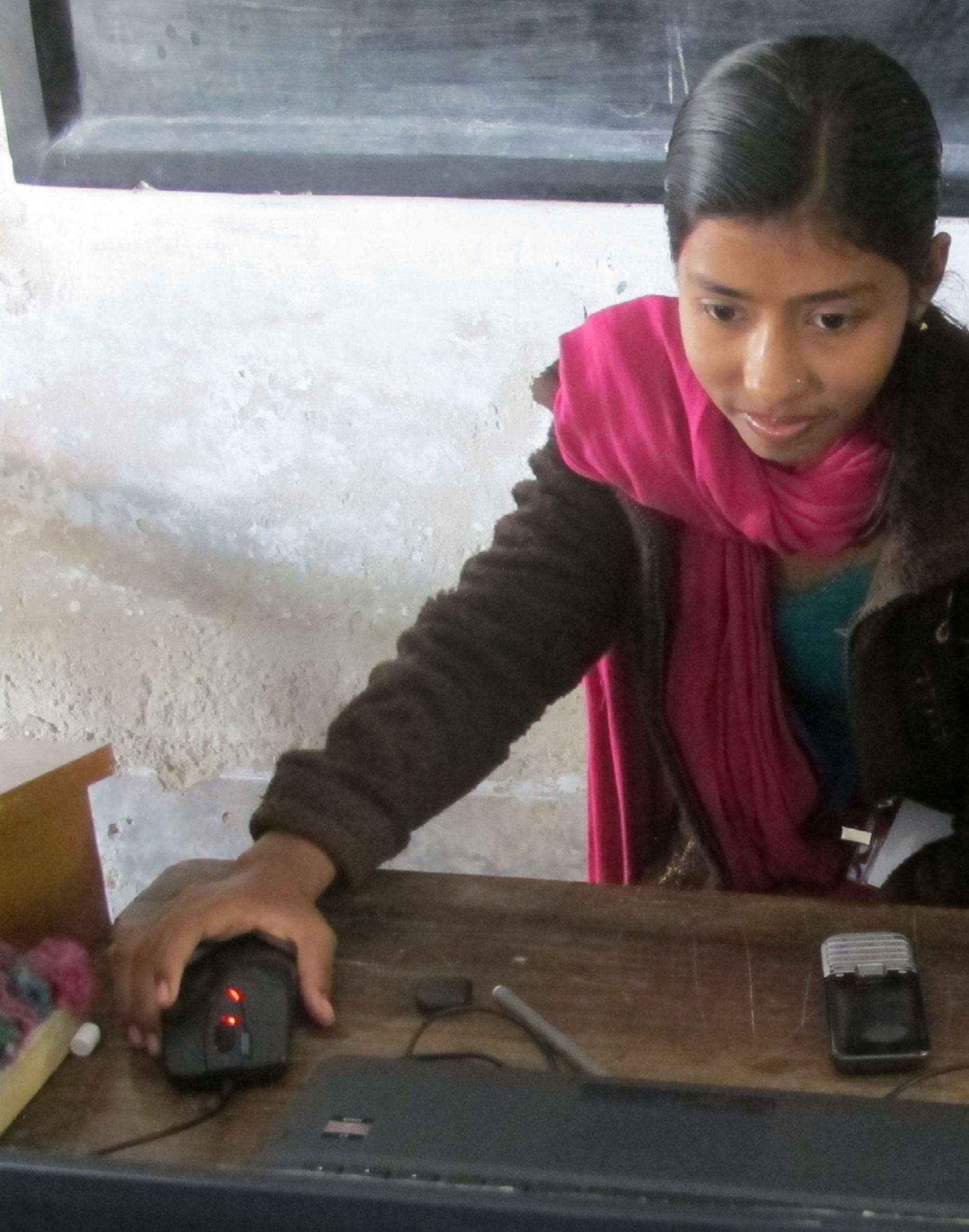




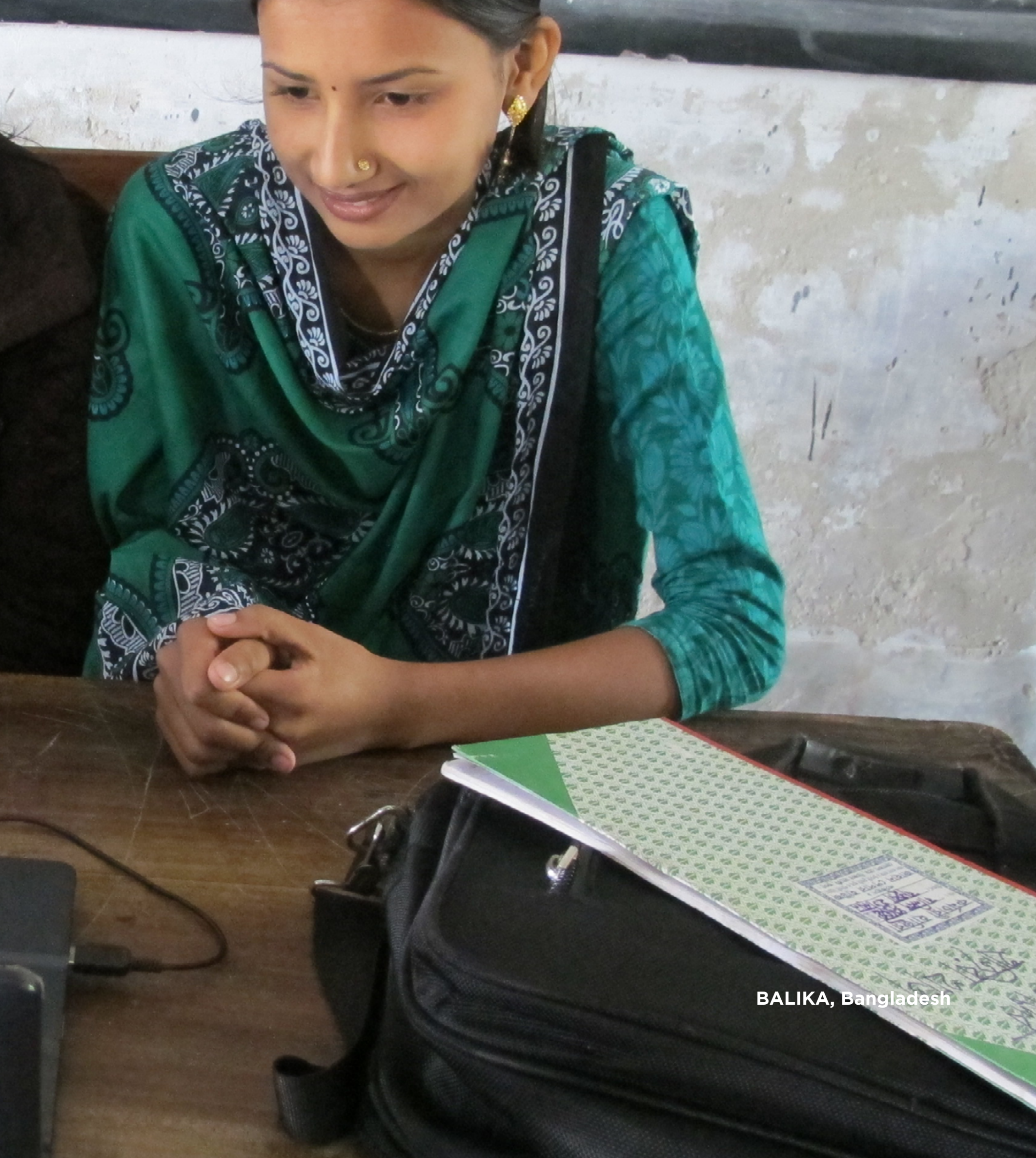


After mentors are trained, their core work begins: forming groups of girls who are similar to each other (in age and life circumstances), and delivering relevant lessons in engaging, interactive ways.

Some programs pair mentors to co-lead groups of 20-30 girls who meet regularly throughout the program. Pairing mentors can help ease facilitation, split tasks, and provide backup in case one mentor misses a session.

For certain exercises in the curriculum, mentors create smaller groups for discussions and exercises. The tools in this section include examples of fun ways mentors can group girls into smaller subgroups. There are also examples of introductory tasks mentors will do with the full group such as setting ground rules for the groups and icebreakers.

This section also includes insights for introducing the participatory facilitation techniques that are used to deliver the key content in the programs. There is information for mentors on talking about sensitive issues, dealing with emotion, and working with parents. 


\section{INTRODUCTORY EXERCISES AND ICEBREAKERS}

\section{Group Introductions ${ }^{21}$}

At the first meeting of the group, all participants should introduce themselves. Mentors can make this as fun or as serious as they feel is appropriate. Here are some ideas for introductions:

- Participants can give their name and their school, or the area where they live. Or mentors can ask each person to say something unusual about herself, to help the others remember her.

- Go around and instruct participants to state their name, favorite food, or favorite animal. Mentors can be creative and think of a different category that may be more enjoyable or relevant to their participants.

- Distribute paper and markers or colored pencils to each participant. Ask participants to draw a picture that tells the others something important about themselves. Give five minutes to draw. Then, one by one, ask each person to give their name and explain their picture. Additionally, mentors can collect the pictures, post them on the wall or on a tree, and sometime later in the day have a contest to see who can match names to pictures.

- Instruct participants to form pairs and tell the partners to introduce themselves to each other. Give them five minutes to talk to each other. Then ask each person to introduce her partner to the group.
- Ask participants to form a circle. Explain that each person must state certain information when introducing herself (mentors might add "something different or special about yourself" to the normal information like name, school, favorite food, or main interests). Then toss a soft ball (or rolled up sock) to someone in the circle who introduces herself. After she has introduced herself, she tosses the ball to someone else in the circle. The game continues until each person has had a chance to give an introduction.

\section{Icebreakers}

"Icebreakers" and "energizers" can be helpful throughout the course of the program to help girls get to know each other and to keep energy high during sessions. ${ }^{22}$ Icebreakers or energizers are quick, simple activities that help participants relax, become more comfortable, and (re)connect with each other while simultaneously energizing them to focus and participate.

Each session should open with a quick icebreaker. Try to choose a new one each time, and try to limit time spent on these to about five minutes. Icebreakers can also be used in the middle of a session to "wake participants up" if energy levels in the group seem low; used in this way, the activity is known as an energizer. Participants themselves often have great ideas for energizers and icebreakers. Give participants a few options to choose from, or ask them for suggestions for a quick game or song to open a session. ${ }^{23}$

\footnotetext{
${ }^{21}$ https://knowledgecommons.popcouncil.org/departments_sbsr-pgy/590/

${ }^{22} \mathrm{http}: / /$ aidsalliance.org/resources/467-100-ways-to-energise-groups

${ }^{23}$ https://knowledgecommons.popcouncil.org/departments_sbsr-pgy/584/
} 


\section{GROUP FORMATION ${ }^{24}$}

Arranging participants into pairs or small groups encourages teamwork and participatory and interactive learning.

\section{Groups/Teams}

- Count off. For example, ask participants to count off by 4s. One by one, each participant will say a number (the first participant says "1", the second says "2," and when it is the fifth participant's turn, she will start again at 1). When everyone has counted, instruct participants to form groups with people who have the same number. In the end, you will have 4 groups.

- Make simple puzzles with 3-5 pieces each. Distribute the puzzle pieces to participants and ask them to find all of the others who have the pieces to complete their puzzle. Be sure to use simple puzzles and have the same number of puzzle pieces as participants.

- Ask participants to stand in line in the order of their birthdays-month and day only-and then count off (such as 1 through 3 ) to form groups.

- Assign colors, symbols, or pictures at random. Instruct participants to find all others with the same assigned color, symbol, or picture.

- Place the names of four well-known pop culture stars in different places around the room and ask participants to stand next to their favorite. If everyone flocks to the same star, adjust the exercise to create more than one group. For example, ask participants to move to their second favorite star.

- Select four different animals (or whatever number of groups you want to create) and write the name of each animal on several slips of paper. The number of slips will depend on how many participants will be in each group. For example, if there are 16 participants, make four groups of four people. In that case, write the name of each animal on four slips of paper. Each participant will draw one slip of paper from a container. Tell participants that when the word "now" is spoken, each person must make the noise of the animal written on her slip of paper. While making their noises, participants must look and listen for those making the same animal noise they are making. These people are their group members.

- Have everyone cross their arms across their chest. Amazingly, it almost always works out to about 50 percent cross right over left, and the other 50 percent cross left over right. Have participants close their eyes and then put their hands together so their fingers are interlocking and their palms are touching each other. Have them open their eyes and look down at their hands. If their right thumb is on top then they are one team and if their left thumb is on top then they go to the other team.

Source: AGEP

${ }^{24}$ https://knowledgecommons.popcouncil.org/departments_sbsr-pgy/584/ 
Pairs

- Form pairs by dividing the total number of participants in half. Ask participants to count off up to the number that represents half of the total. For example, if there are 20 participants, they will count off up to 10 and then start again at 1. The two people who have the same number are partners (the $1 s, 2 s, 3 s$, etc.).

- Ask participants to turn to the person on their right (or left). This person is their partner.

- Create sets of pairs constructed around opposite words or similar objects or first and last names of famous people. The number of pairs you create should equal half the number of participants. Each pair must have two parts. Write one word of each pair on a slip of paper. Ask participants to draw a slip of paper from a container and find the other half of their pair. This is their partner. Some examples for a group of 10 participants include:

\begin{tabular}{|l|l|l|l|l|l|}
\hline \multicolumn{2}{|l|}{ Opposites } & \multicolumn{2}{l|}{ Matching objects } & \multicolumn{2}{l|}{ Famous people } \\
\hline black & white & bed & sheets & Nelson & Mandela \\
\hline sad & happy & table & chair & Bob & Marley \\
\hline dark & light & camera & photograph & Jua & Kali \\
\hline tall & short & car & driver & Michelle & Obama \\
\hline wide & narrow & shoes & socks & David & Beckham \\
\hline
\end{tabular}

The group's theme can provide the inspiration for the selection of paired words. Or, select famous people who are relevant to the age range of the participants. For example, music, sports, and movie stars tend to work well with young people.

- Ask everyone to pick a number between 1 and (choose the upper number depending on the size of your group). Line them up according to which number they picked. The two people at the end of the line become partners, the next two become partners, etc. Those who have picked the same number become partners. If only one person chooses a particular number, ask them to choose another number.

- Groups line up according to any variable. Examples are: oldest to youngest; tallest to shortest; alphabetically by first or last name; chronologically by month and date of birthday. Make the process more challenging by not allowing participants to talk. The two people at the ends of the line become partners, the next two become partners, etc.

\section{Seating Arrangements}

To encourage participants to feel a sense of membership to a group and to participate fully, it is strongly recommended that they sit in a circle rather than in rows. This seating arrangement allows for eye contact between participants and the facilitator, creates a more relaxed atmosphere, and encourages participation. 


\section{SET GROUND RULES}

Ground rules for activities are essential for managing group sessions. Ground rules help maintain peace and order, and provide a framework for participants to be respectful and productive. Rules should be kept visible for all sessions and referred to as needed throughout the modules. The following are some sample ground rules:

- Listen to what other people say.

- No talking when someone else is talking.

- Be kind and give support.

- If people do not want to say anything, they do not have to.

- Do not laugh at what other people say.

- Insults are not allowed.
- The opinions and statements of all girls are valued equally.

- All experiences will be shared in a climate of privacy and trust.

- If you wish to speak, raise your hand and wait to be called upon.

- Questions are encouraged and may be asked at any time. There is no such thing as a stupid question. It is okay to blush, feel embarrassed, or not know the answers to all of the questions.
- The facilitator may choose not to answer a question in front of learners.

- Things shared will be kept strictly confidential. They will not be discussed outside the group.

- Do not judge people because of what they do or say.

\section{Activity}

Participants create a list of ground rules for all sessions, and brainstorm a list of community resources

\section{Objectives}

By the end of this session, participants will be able to:

- Establish, negotiate, and agree on ground rules as a group

- Have a list of community resources available to them for sexual and reproductive health, gender-based violence, and other services

Time

1 hour (icebreaker, 10 minutes; review, 10 minutes; ground rules, 20 minutes; brainstorming community resources and contacts, 20 minutes

\section{Materials}

- Flip chart and markers

- A comprehensive list of local community resources and contact information for sexual and reproductive health services; HIV testing and counseling; how/ where to report sexual or domestic violence; psychosocial counseling; referral for any vulnerable girls who have been abused or raped; legal services. (It may be helpful to produce index cards with images of these community resources.)

\section{Pre-session Preparation}

- Read through the entire session and, if necessary, practice presenting the activities.

- Prepare all materials needed for the session.

- Talk with community members to ensure that as many people and places as possible are included on the list of community resources, and that all contact information is up-to-date and correct. 
Terms

- Group Norms: The standard behaviors and characteristics of a group

- Ground Rules: Basic rules set to help you feel safe and respected, and maintain productivity

- Community Resource: An organization, institution, group, or person in the community that provides assistance and support to those at risk

\section{Icebreaker}

- Open the session with an icebreaker of your choice, or allow participants to suggest one.

- It is appropriate to choose a longer icebreaker or trust-building activity because of the relatively short amount of time needed to cover the content in this session.

\section{Procedure}

Ask:

Are you familiar with ground rules or group norms? Why do you think it is important to establish ground rules? (To understand the limits and freedoms of a context, to improve team work, to ensure productivity and respect)

\section{What are some real-life situations when it is} important to have rules? (E.g., when someone steals something, when there is a meeting and everyone talks at the same time, when someone speaks and others make negative comments about their contribution to the conversation, when everyone contributes to household chores, etc.)

\section{Explain to participants:}

Ground rules or group norms are set to help you feel safe participating in these meetings. While this is a participatory program, you will not be forced to participate more than you want. You can feel confident that this is a safe environment in which to share your thoughts and feelings, and that sharing your own questions or stories can help other girls who may have experienced or wondered about similar things. Ground rules help ensure that everyone will have a chance to be heard without judgment or ridicule, and that their personal boundaries and privacy will also be respected.

Ask:

What are some ground rules you would like to set for these meetings? (E.g., what is said is not repeated anywhere else; everyone should participate only if they want to; no putting someone else down for their feelings, opinions, or experiences; be respectful; listen and do not interrupt, etc.)

Record ideas for ground rules on a flip chart and post them for reference throughout the entire program.

(Write in simple terms [also using pictures] to accommodate for all literacy levels.)

\section{Now ask:}

What are some interactive punishments you would like to set for those who break the ground rules? (E.g., the violator must do 10 frog jumps, the violator must write on the chalkboard or flip chart [or say out loud three things they have learned so far today], the violator must sing one verse of a song, etc.)

Also record these responses on a flip chart paper and post for reference throughout the entire program. Then explain to participants that they will now vote to agree on these rules by raising their hands. Explain that this vote will serve as a contract, meaning that the group has agreed to follow these rules in each girls group meeting. Initiate the vote. If one or more girls do not raise their hand, ask why and discuss what should be changed to the rules in order for everyone to agree to them. 


\section{FACILITATION: TEACHING TIPS FOR MENTORS}

Facilitation, rather than simply lecturing, is a new way of interacting for most mentors and program participants. The following sets of tips offer suggestions for creating a positive learning environment, dealing with sensitive issues, and preparing prior to a session. ${ }^{25}$

\section{Creating an appropriate learning environment}

Remember that the mentor does not have all the answers. The participants come to the learning sessions with a great deal of experience and have many things to add. In the session, it is important that mentors and participants teach and learn.

- Create a safe learning environment.

- Give feedback to the participants and praise them for their efforts.

- Think about ways of making the topic useful to all participants present.

- Let the participants know that you are a learner with them, as well as a leader and a mentor.

- Promote conversations and questions that allow young people to explore and clarify their values as they develop a sense of self.

- Use a variety of activities that are appropriate for different maturity levels to cover young people's many developmental stages.

- Make the learning relevant to young people's current situation. Be cautious about asking them to project far into the future.

- Anticipate that young people may have limited experience with a topic. Stories may have to substitute for real-life experience.

- Be sure that throughout the session there is an opportunity for thinking, acting, and feeling.

- Include current media to ensure relevance of the topic and to promote discussion.

- Engage participants' families and communities to connect with the program, understand its content, and support the young people in changing behaviors and meeting goals.

- Encourage humor and use interactive games so that the training is dynamic and fun!
Establish a learning environment based on equality, respect, and human rights

- Create a supportive learning environment. All participants should feel involved, listened to, comfortable, and safe from ridicule, especially when they take risks with new ideas.

- Encourage participation, particularly among those who feel alone or intimidated. (Various conditions and situations can trigger such feelings. For example, differences in social power associated with gender, social class, or age can be a factor. Participants with limited fluency in the language spoken at school may avoid joining discussions. Those living with a physical disability or other special needs may feel shy.) Boost group involvement by using activities that promote respect and team building and by spreading leadership opportunities. Of course, it is also important to ensure the safety and privacy of the physical space.

- During an early session, ask participants to work together to devise a list of guidelines to ensure respect within the group.

- Ask participants to respect other people's privacy, and remind them not to disclose information to others that they feel should be kept private. Consider how some participants might intimidate or even abuse others after leaving a group session in which sensitive topics have been discussed. Assure them that the mentor will keep all discussions confidential. In this way, mentors can serve as a role model for respecting others' privacy.

- Make certain that they understand that they have the right not to participate or share if doing so makes them uncomfortable.

- Encourage all participants to share their thoughts. Do not judge their ideas.

(1 of 3) 


\section{MENTOR}

\section{General facilitation tips}

- Foster a process that draws on participants' experiences, integrating new information and ideas into what they already know and think about a topic.

- Remember all participants have knowledge and experience. Listen and ask questions to draw them out.

- Listen to their concerns and pose hypothetical problems that reflect their real lives. Engage them in solving these problems, making their own choices and developing their ideas along the way.

- Encourage them to explore the significance of an issue in their own lives.

- Think of the mentor role as facilitating discussion of participants' ideas rather than as a lecturer or transmitter of information. Sometimes a mentor may need to correct factual errors or help participants recognize when a comment is disrespectful.

- Occasionally, it may be useful to share an example from personal experience that is relevant to the lesson. However, be extremely careful to maintain appropriate boundaries with the participants.

\section{Build on participants' power to reflect, study, and} think critically about their own lives and the world around them, and to solve problems

- Encourage participants to question conventional wisdom. Ask them to think about their beliefs and their community's standards and norms. Invite them to explore opinions different from their own in a respectful manner.

- Encourage creativity.

- Encourage participants to take risks in their thinking and to be unafraid of making mistakes. Be willing to demonstrate such behavior yourself.

- Organize small groups to explore issues and engage in collective activities.

- Encourage various perspectives in analyzing problems and suggesting possible solutions.

\section{Attributes of a good facilitator}

- Sees the participants as experts with information and skills to share, rather than seeing themselves as the only experts in the room.

- Encourages participants to learn from each other and guides this process rather than providing direct instructions and lecture-style learning.

- Believes we learn by doing, experiencing, practicing, and feeling, rather than by memorizing, repeating, and recording information.

- Is organized, but is flexible in changing methods based on participant needs.

- Is enthusiastic about the topic and participants.

- Keeps promises to the group (to let participants speak, take a break, etc.)

- Is patient and a good listener.

- Is prepared to handle strong emotions that may arise during discussions.

- Fosters participants' ability to apply what they learn to their lives and communities, that is, helps them become active citizens and forces for positive change.

- Repeatedly ask participants to relate the content to their own lives and world. Encourages them to consider the material in light of principles of fairness and social justice.

- Is aware of the environment you work in so that you can avoid putting participants in harm's way.

- Keeps in mind that young people often draw inspiration from their teachers and community leaders. 


\section{FACILITATION: TEACHING TIPS FOR MENTORS (continued)}

\section{Preparing for sessions}

\section{Before each session:}

- Carefully read through all of the session's background notes and activities. Think about how you will perform each step and what you will add to every session.

- Try to anticipate questions that may be asked, and know where to look for answers in the materials provided. If participants ask questions that you cannot answer right away, write them down and follow up on them before the next session, so that you can discuss them then.

- Adapt the activities and group discussions to make them more appropriate to the age and education level of your participants.

- Think about and plan for any issues that may arise during more "difficult" sessions with complex material or sensitive topics.

- Think of local examples and ways to make the activities more relevant to the participants' daily lives and concerns. When possible, work from easy to difficult subjects.

- Have materials prepared beforehand.

\section{Additional facilitation tips}

- Have a "parking lot" for issues that arise during a session, but that are not relevant to the session objectives. You can come back to them at another time or simply explain at the end of the training that it was important but outside the topic of the training.

- Capture important points on flip chart paper during discussions for use during the summary activities. It can be very challenging to both lead the discussion and write down all important points, so consider having someone assist you in writing down key points.

- Whenever appropriate, identify next steps or possible solutions to problems.

- Relate the information to what has been learned in previous sessions whenever possible.

- Check to make sure you are not speaking more than the participants. If you find that you are doing most of the talking, encourage participants to answer each other's questions. For instance, if someone asks a question, open discussion to the participants with the inquiry: "Does anyone have an answer to that question?"

- The way you hold your body will help effectively facilitate the group. For example, looking attentively and nodding makes participants feel their contribution is important. Looking away can effectively tell the person not to talk or participate. Always face the person to whom you are speaking.

- Have fun! ${ }^{26}$ 


\section{TALKING ABOUT SENSITIVE ISSUES: TEACHING TIPS}

Many programs provide specific guidance for mentors on talking about sensitive issues. Some mentors may feel that talking about sex and contraception with young people encourages young people to have sex. On the contrary, research shows that talking with adolescents about facts and consequences related to sex encourages them to delay sex and consider abstinence. However, mentors should not assume the participants are not having sex. Young people will often giggle with embarrassment when discussing topics related to sex or reproduction. Mentors should not let this discourage them or make them uncomfortable. Girls need accurate information on these subjects to make healthy choices and feel more comfortable with the changes they are experiencing. Consider having all the girls say "vagina" or "penis" together to help them get their giggles out. Let the embarrassment pass, wait for girls to settle down, and then focus on the information and skills they need.

Tips to let participants know that mentors are comfortable talking about sensitive issues

- Mentors should think about their own values and clarify how they feel about an issue before discussing it with participants.

- Be prepared and plan ahead. Find out as much beforehand in order to feel confident when facilitating the session.

- You do not have to know everything. Be honest with participants when you are not sure how to answer their questions. Turn the question into an investigative project and ask participants to help you find the answer. Tell them that you will also ask a health-care provider or another expert and try to have answers for them at the next session.

- Accept participants' slang terms. Don't be afraid to ask what they mean if you don't know.

- Do not dismiss or look down on what participants know. Participants have been exposed to a variety of information and experiences. Their experiences have value and are important.

- Set your own limits. Participants will be excited because you are prepared to talk about topics that interest them. Few adults guide them or give them this knowledge, so they may ask questions that make you feel embarrassed. Be as open and honest as you can, but tell them when it is enough or when their behavior is disrespectful.
Explain when you feel uncomfortable answering a particular question.

- Do not answer personal questions about your own sexual experience. If these questions come up, let participants know that your role as a facilitator is not to discuss your own experience.

- Stick to the facts. You might have personal opinions about the topic, or how you personally would act in a certain situation, but it is important to remain neutral and open so that the participants will feel free to ask any question and share their thoughts, fears, and opinions.

- Get advice and help if you need it. Teaching topics like Life Skills and Reproductive Health is not easy. If you had a difficult session, find someone you trust to talk with afterward. However, respect the participants' privacy and do not share personal information that participants shared with you during the session, unless you feel they may be in danger. Information from participants may be shared in meetings between mentors, as long as the identity of the participant involved is not disclosed. 


\section{TALKING ABOUT SENSITIVE ISSUES: TEACHING TIPS (continued)}

\section{Handling emotion}

Participants may get emotional during group meetings. Mentors should react sensitively and effectively when a participant becomes visibly upset during a session. Mentors should strive to ensure that participants feel safe and are not embarrassed so that the group can move past any awkwardness or discomfort.

\section{Ways for a mentor to deal with an emotional situation}

Move the discussion away from an upsetting topic, relating an anecdote, moving on to a new topic, or taking a break. Participants may also get upset by some of the topics in the group meetings. They may have doubts about themselves or may feel uncomfortable talking about issues related to sex with other adolescents. The discussion activities may remind them of uncomfortable situations they've been in before the meeting, at home or at school.

If a participant is upset by an activity, the mentor should try to talk to the participant privately in order to find out how and why the participant is uncomfortable. The mentor may suggest that the participant step out of the meeting space and should not force the upset adolescent to talk about what is upsetting her, but should be available to listen if the girl would like to talk. Listen to what the participant says.

A mentor's role is to provide her with understanding, support, and assistance. The mentor should not tell the participant how she feels or how they think she should feel; instead, assure her that it is normal to feel upset. Please note: As a mentor, you should be prepared to provide a participant who has been abused with contact information for psychosocial counseling. The program will provide you with this information and you should have it on hand before the first session..$^{27,28}$ 


\section{ENGAGING MENTEES AND PARENTS}

Curricula use participatory teaching methods, such as group discussion, brainstorming, role-play, small group work, educational games, and storytelling. Mentors may prefer to give a lecture and may find facilitating a game or other interactive exercise a bit challenging. However, games and activities provide participants with opportunities to interact freely, and often generate discussion that cannot be yielded by other methods. Participatory techniques also provide participants with opportunities to practice using new skills (e.g., communication and decision-making). Remember, group meetings are meant to be a fun and relaxed environment, NOT one that resembles a classroom! Imagine a training session that is active, sometimes noisy, and fun.

\section{Advantages of active participatory methods}

- Improved critical thinking skills

- Increased likelihood of participants remembering and sharing new information

- Increased motivation

- Improved interpersonal skills

\section{Examples of participatory methods}

Brainstorming. Brainstorming is an exploration of ideas and is a great way to open a topic for discussion. During brainstorming, no one should judge or place value on an answer someone gives. Each answer is simply recorded on paper or a chalkboard. This activity encourages participants to expand their thinking about an idea and consider a topic from different angles and perspectives.

Group discussion. Group discussion brings out responses from participants on a particular topic, and provides opportunities for the facilitator to increase participant knowledge or correct misinformation. The effectiveness of the group discussion often depends on a facilitator's ability to use open-ended questions, which are questions asked by the facilitator that need more than a simple "yes" or "no" answer. These questions help to bring out feelings or thoughts about a topic or an activity.

- "What did you learn from this activity?" is an open-ended question. "Tell me how this activity affected you?" is another example of an open-ended question. Open-ended questions often start with What, When, Why, or How.
- “Did you learn anything?" is not an open-ended question, because the participant can simply say yes or no.

Role-play. Role-playing provides participants with an opportunity to experience a real-life situation, without having to take real-life risks. It is important that mentors encourage participants to role-play realistic situations, and not ideal situations.

The rules of role-play are:

- Discuss the situation within your own small role-play group.

- Agree on a storyline.

- Agree on who does what, involving everyone.

- Rehearse.

- Act out for the larger group. ${ }^{29}$

Stories: Stories can help illustrate the main themes of the day's lesson. Make sure to read these stories before you deliver them, so that you tell them in a lively manner, without reading directly from the page. If a photocopy machine is available, make copies for each girl. 


\section{ENGAGING MENTEES AND PARENTS (continued)}

Pictures: Another way of making learning sessions more lively and engaging is to use pictures.

Alternatively, real objects can be used to represent the pictures.

\section{Guest speakers}

Any time it is convenient and possible to bring in a guest speaker, mentors should do so. Girls will always benefit from meeting and learning from women they identify with who can serve as positive examples and/ or role models. ${ }^{30}$

\section{Working with parents or caregivers/guardians}

- Keep parents informed about what you are doing and why. However, parents do not have to know every detail of what is discussed in the program, and the confidentiality of what participants share in group sessions must be protected.

- Get the opinions of parents.

- Talk with parents about their concerns and fears around reproductive health and HIV and AIDS (or other sensitive topics relevant to your program, like child marriage, female genital mutilation, and gender-based violence). Do this through the program's parents' meeting, home visits, community days, etc.

- Invite parents to meetings to discuss their concerns.

- Know the community. Find out about its needs and concerns, as well as the skills and expertise of the parents. For example, a parent might be a nurse at a local clinic who could talk to the participants and give you advice and support.

- Offer talks on parenting skills. Bring in experts to present their ideas, help improve parent-child communication, and share resources and materials.

- Involve parents. Ask parents to check homework, and assign activities that require participants to talk to their parents. For example, ask participants to interview their parents or family members about when they were young. ${ }^{31}$

${ }^{31}$ https://knowledgecommons.popcouncil.org/departments_sbsr-pgy/584/ 


\section{SESSION PLANNING}

During training workshops and regular meetings, mentors should study curriculum guides and plan upcoming sessions. The study and session planning strategy outlines eight steps to prepare prior to implementing a session. Ideally mentors will prepare in groups so they can discuss adaptations to activities proposed in the curriculum guide. Over time, each group can determine and design a preparation strategy that works for them.

When planning and before holding a session, mentors must:

- Know and understand the issue that will be discussed during the session.

- Understand the objectives set for the session.

- Adapt the activities to be attractive and meaningful to participants.

1. Familiarity. Read the entire session in silence and mark unfamiliar words or content that is unclear.

2. Vocabulary comprehension. Write unknown words on a flip chart as a single list. Mentors will share their intuitions about each word to come up with a definition among themselves. At the end, they can compare each definition with one in a dictionary.

3. Session objectives. Read the objectives established for the session and discuss how each one will strengthen adolescent girls in the community.

4. Key issues and concepts. Each mentor will take a key concept and translate it to her mother tongue (if relevant), so the concept is available in the dominant language in the country and the local language, if relevant. Mentors are not expected to literally translate the concepts, but to express the sense and meaning of the key concept in the language in which they will be working with the participants, if other than the language the curriculum is written in.

5. Contextualized activities. As a group, mentors will read the session in the curriculum guide, listing each activity. They can adapt/modify/add activities to ensure that they are relevant to adolescent girls' lives and local culture.

6. Plan. Create a planning form to help describe activities.

7. Check. Mentors return to session objectives and verify that they are met.

8. Materials and resources. Prepare the materials needed for the session. ${ }^{32}$

\begin{tabular}{|l|l|l|}
\hline Session type & Session name & Session date \\
\hline & & \\
& & \\
\hline
\end{tabular}

\begin{tabular}{|l|l|l|l|}
\hline Activity & Activity description & Materials & Estimated time \\
\hline & & & \\
\hline & & & \\
\hline & & & \\
\hline & & & \\
\hline
\end{tabular}

Source: Abriendo Oportunidades

${ }^{32}$ https://knowledgecommons.popcouncil.org/departments_sbsr-pgy/593/ 


\section{GAMES AND PARTICIPATORY EXERCISES ${ }^{33}$}

\section{Games to support Financial Education}

\section{THE BIG BEAN}

\section{Materials:}

2 tokens

30 beans/corn kernels/pebbles

2 glasses as saving glasses to deposit the beans

Objective: Accumulate the largest number of beans in the savings glass.

\section{Instructions:}

- Two teams with an equal number of participants are formed, lining up in rows.

- The savings glasses are placed at one end of each row.

- The first participant in each row is given a token, which must be put under her clothes (blouse-shirtneck of the dress) and removed at her feet (pants, skirt, shorts). She passes it to the next in line to do the same and so on until the token reaches the last participant.

- The last participant must go to a distant point, where the beans are located. She takes a bean and runs to the beginning of the row to deposit it in the savings glass. The process is repeated several times by giving a new token to the first person in line to repeat the exercise until time is up.

- The winning team is the one that collected the most beans in their savings glass.

\section{Reflection:}

If we are organized and have a plan, we can have better savings.
THE PIGGY BANK

(An adaptation of Rabbits and Hutches)

Materials: A large area to play

Objective: Understand that savings are a resource to be set aside and kept in a safe place.

\section{Instructions:}

- Form groups of three participants.

- In each group, two participants take each other's hands (representing the piggy bank) and one participant is placed between them (representing the coin)

- The facilitator alternately shouts "coin" or "piggy bank."

- When she says "coin," the participants leave the piggy bank and look for another piggy bank to hold them.

- When she says "piggy bank" the pairs move looking for another coin to save.

\section{Reflection:}

- It is important to have a safe place to save.

- It can be a piggy bank or a bank, with organized groups in the community, or in a cooperative. 


\section{THE DANGEROUS STEP FROM COINS TO SAVINGS}

\section{Materials:}

Flip chart for each group

Markers

A coin

Glass with a sign: Savings

Objective: To encourage communication and organization among the team to achieve their planned goals.

\section{Instructions:}

- Form two rows with five members each.

- Each group must identify five common expenses that people face that put savings at risk.

- Make a poster for each expense and place it in a visible place.

- Groups form two rows. The first member of each row is given a coin, and a glass that says SAVINGS is placed at the opposite end of the row. The goal is to pass the coin between them, using only their feet, until it reaches the glass at the end of the row. If the coin falls to the ground on its journey it will be taken to the beginning of the row to start again.

- You can use as many coins as you like to enliven the game. The first group to place all the coins in the glass is the winner.

\section{Reflection:}

- How did the girls feel about passing the coin with their feet?

-What was needed to successfully pass the coin?

- What would they use the coins for that they collected?

- Is it easy or difficult to save?

- What challenges will you encounter in saving?

- How can women organize themselves to support each other in saving?

\section{HIDE THE COIN}

Materials: Several coins

Objective: Identify that savings should be set aside and not considered a resource for spending on unnecessary items.

\section{Instructions:}

- The girls are grouped into pairs and one of the two is given a coin.

- The girl with the coin hides it in one of her hands. While doing this, the group sings a song: "Hide the coin, hide the coin, hide the coin, hide it well, hide it in the little piggy, so you do not spend it, whoever spends it will not have any savings."

- At the end of the song the girl's partner must guess in which hand the girl has saved the coin. If she guesses correctly, it is her turn to hide the coin, otherwise she will continue to guess until she succeeds.

\section{Variation:}

All the girls are placed in a circle with their hands closed. The coin is placed in the hand of one of the participants, who must pass it hand to hand, but without completely opening her hands, making sure no one ever sees the coin. The game ends when the coin has been passed to all the participants.

\section{Reflection:}

- Why is it important that the coin be well stored?

- What would happen if we were seeing it all the time or did not have it in a safe place?

- What savings strategies are you going to start practicing? 


\section{GAMES AND PARTICIPATORY EXERCISES (continued)}

\section{Games to support Financial Education}

\section{THE TRAFFIC LIGHT}

Objective: Evaluate the degree of communication that exists among the group of participants.

\section{Instructions:}

- One girl will lead the game while the rest form pairs. She will lead by singing "Green," "Yellow," or "Red," and the pairs must follow an instruction: -When she says GREEN, the pairs will look at each other face to face.

-When she says YELLOW, the pairs will stand back to back.

-When she says RED, they all change partners and the one who is alone looks for a new partner.

- Whoever is left on her own will oversee the game.

\section{Reflection:}

- With each color, what is communication like between people? Green is good, yellow needs improvement, and red is broken.

- How is the communication between us?

- How do we solve our conflicts?

- What unites us as a group?

- Do we know how to ask for help when we need it? Who do we turn to?

- What can I bring to the group for a better relationship?

\section{THE PIGGY BANK SONG}

Objective: Think about the good uses of savings and motivate participants to continue saving.

"I have a piggy bank, a piggy bank for saving; when I have some dough, I put in a buck.

That's what my hand makes me do. My hand makes me do that.

I have a piggy bank, a piggy bank for saving; when I have dough, I put in more and more.

When it is very full I will need to buy: fruits and vegetables to eat healthy."

So little by little, I want to save So that in my future I never stop studying.

\section{THE COIN}

Objective: Recognize that saving requires effort, but that it is possible.

\section{Instructions:}

- The participants make a circle holding hands. A volunteer is asked to be the coin and stay out of the circle; her goal is to be able to get inside the circle when she is called to the piggy bank.

- The members of the circle sing to the coin: Coin, coin, enter my piggy bank

- The participant who is outside the circle asks: Where?

- The members of the circle open a space that closes quickly saying: Over here.

- This will be done several times until the girl is able to go into the circle.

- And the game starts over again with new volunteers who are willing to act as coins. There may be only one coin or several at a time.

\section{Reflection:}

- How did the people who were the coin feel?

- How does this relate to our lives with regard to our own savings? 


\section{TOMATO PASTE AND SUPER TOMATO}

Objective: Understand the difference between necessities and luxuries.

\section{Instructions:}

- Form two groups to compete with each other.

- Each group is given a sheet that on one side has the word "Super Tomato" and on the other side "Tomato Paste."

- On the "Super Tomato" side they write things that are desires, whims, and luxuries. On the other side they write things that are necessities. Given a time limit, each group makes the longest list they can.

\section{Reflection:}

- Compare both lists and analyze those cases where it is not clear if the item is a necessity or a luxury.

- Estimate the cost of the luxuries and compare with the cost of the necessities.

- Prioritize spending according to the degree of need/usefulness of the items listed.

\section{SAVINGS CROSSWORD}

Objective: Identify important elements of saving.

\section{Instructions:}

- Place a flip chart with the incomplete crossword and the letters that complete the words.

- The participants are asked to solve the crossword by filling in the empty spaces with the letters they have available.

\section{Reflection:}

- When completing the crossword, participants should make sentences using the words they formed.

- Participants can also write the questions that serve as a clue to each of the words they placed.
Horizontal:
Vertical:
1. Coin
1. Savings
2. Save
2. Earn
3. Piggy Bank 


\section{GAMES AND PARTICIPATORY EXERCISES (continued)}

\section{Games to support Sexual and Reproductive Health Education}

Games and participatory exercises also support and reinforce lessons from sexual and reproductive health lessons. ${ }^{34}$

\section{WORD SEARCH}

Instructions: Give each team a word-search poster containing the following words:

Vagina

Uterus

Ovary

Womb

Vulva

Anus

Penis

Woman

Menstruation

- The word search on each poster must have words hidden differently.

- Each team must find the hidden words. If a group finishes first, the girls can help the other group find the words. They can then review the location, the functions, and the personal hygiene for each of the words.

"I WANT ..." SONG

I want to sing,

I want to see,

I want to feel,

I want to touch,

And to know my body

Here I touch (they point to a part of their body)

Play several times until as many body parts as possible are mentioned.

\section{Reflection:}

The girls can reflect on the importance of knowing the different parts of their body, what they are like, and awareness of everything that happens in their bodies as they grow.

\section{SPERM AND EGGS}

(An adaption of Rabbits and Hutches)

\section{Instructions:}

- Form groups of three participants.

- Two girls in each group will hold hands representing the egg, and the third one stands in the middle representing the sperm.

- There must be one or two girls without a group whose goal is to find a group they can join.

- When the mentor shouts "egg," those who hold hands move to look for someone who represents the sperm.

- At this moment, the girls who did not have a group at the beginning are incorporated into the game, leaving others on the outside.

- Then the mentor will shout "sperm" and only the girls who represent the sperm will move to find another egg to receive them.

- Girls who are left outside can ask their peers questions about what they know about eggs, ovaries, sperm, fertilization, pregnancy, etc.

\section{LEG TUNNEL}

\section{Instructions:}

- The girls form a long line standing with their legs open to make a tunnel. The last one in the line must go through the tunnel until she comes out in front, being careful not to bump any partner and not to get bumped herself.

- They continue like this until all the girls have gone through.

- This activity allows them to develop trust among themselves while they are in their safe space. 


\section{"THIS IS MY HOUSE"}

This game can be done with an unlimited number of participants, who form a circle.

\section{Instructions:}

Participants sing the following song that mentions parts of a house, and each of them must point to a body part that resembles the part of the house that is being named.

This is my house and this is the neighbor's house. This is my door and this is the neighbor's door. This is my window and this is the neighbor's window.

... and so on with the body parts.

\section{Reflection:}

- The game offers a space to reflect that there are parts of the body that we allow to be touched and others that we do not.

- One of our sexual rights is that nobody can touch you if you do not want them to.

- If there is a girl who does not want to play, she has that right, until little by little she decides to play.

- After the game, explain that each part of the body has its own name and after the explanation they must play again using the correct names.

House: whole body

Door: mouth

Windows: eyes

Pillows: breasts

Kitchen: stomach

Fan: buttocks and anus

Faucet: urethra

\section{PASS THE TOKEN}

Objective: The group is divided into two teams standing in two rows. The goal of the game is to move from competition to cooperation and trust.

\section{Instructions:}

- In the first phase of the game the girls must give a token to the first person in each row, and it must be put between their clothes (down the blouse and out the leg of the pants), and when finished it is passed to the next player.

- The row that manages to make the token reach the back of the line and return forward first, wins.

- In the second phase of the game, the girls are asked to look at each other and to join hands to form a bridge.

- A group volunteer will lie on top of the arms with the intention of reaching the end of the bridge only by way of the girls moving their arms. The volunteer's partner can wait for her on the other end to help her down. This can be played several times if there is more than one volunteer.

- At the end ask the girls what they felt in each phase, what kind of physical contact there was, how they felt, and why they felt that way. Differentiate this from other forms of physical contact that makes them feel uncomfortable and that they have the right to reject and report to stop it. Eliminating competition between them allows the girls to see the importance of support among women.

\section{BODY LOTTERY}

Objective: This game is to reinforce the identification of body parts, see what they look like, and see how they are written in different languages a girl may use in her daily life.

\section{Instructions:}

- Lottery is played with a card that presents drawings of body parts that are written in the local language (if relevant) and in the dominant language.

- The mentor can also call "lottery," using cards with body parts. 


\title{
GAMES AND PARTICIPATORY EXERCISES (continued)
}

\author{
Games to support Sexual and Reproductive Health Education
}

\section{PLAY FAMILY ROLES}

\section{Instructions:}

- The girls form two groups. Group 1 is a family of two parents with three children, and Group 2 is a family of two parents and six children.

- The mentor distributes a piece of tortilla (or other relevant local food) to each group and asks each group to share it among the members of the family. Then, she teaches about the pieces of food that correspond to each group.

- The groups reflect on how the number of children they have affects the resources that can be offered to each one.

- They consider that family planning includes how many children, and also the parents' plan for how they will provide for their sons and daughters. With teenagers, this can be an introduction to the subject of family planning methods.

\section{PAPER HUNT}

\section{Instructions:}

- The mentor prepares seven papers shaped like girls' body parts.

- Each paper is hidden within the safe space.

- Formed in seven groups, participants look for the papers and put them together to assemble the silhouette of the whole body.

- When they finish, they name the parts of the body, their functions, their care, whether they can be touched or not, among other comments.

\section{DICE}

Instructions:

- Mentors should prepare a die by writing on each face a question related to their body.

- The girls form a circle and wait for the mentor to throw the die. The participant who catches it must answer one of the questions that is on the die, then she passes it on to another girl in the circle.

- Some questions can be: What nicknames are given to different parts of the body?

\section{CHARADES}

\section{Instructions:}

- Form two groups. One group leaves the room and the other one stays inside.

- The mentor explains that the outside group will present charades to the group inside so that they can guess them.

- The charade topics may vary; some may be: sexual and reproductive rights, reproductive stages of life, methods of family planning.

- The mentor indicates which topic and the group agrees before entering to present to their classmates.

-When the group is ready they enter and say: We are coming! The other group answers: What message do you bring us?

- The charade is done, and they can make four guesses.

- If they do not succeed, the group explains what they are trying to present. 


\section{HYGIENE FOR MY BODY}

\section{Objective:}

Sing a song that invites participants to learn how to clean their body parts.

\section{Instructions:}

The mentor assigns each girl a body part and asks her to think about how she cleans it. The song can be in English or a local language.

Look how I do it,

Everyone does it this way.

Go around to each of the girls, mentioning different parts of the body. Reflect that it is important to keep all our body parts clean so as not to get sick or make other people sick.

Hands: scrub with soap and water.

Hair: wash, comb, and untangle.

Teeth: brush with toothpaste and toothbrushes.

Vulva: wash with soap and water.

Underarms: wash with soap and water.

\section{Reflection:}

- What is menstruation?

- How does it make you feel that you are going to menstruate?

- Mention a sexual right that you know.

- Mention a reproductive right that you know.

\section{HEADS OR TAILS}

\section{Instructions:}

- The mentor brings a token and throws it into the air.

- She asks the girls to choose whether it's heads or tails.

- Those who called the side on which the coin falls gather to answer the question that the mentor will ask them.

- Together they discuss it and respond as a group.

- The mentor carries a list of questions about body parts. The questions can be:

What is a vagina?

What is menstruation?

What is the function of the ovaries?

What is the function of the fallopian tubes?

What is the function of the uterus?

\section{MARBLE STATUES}

\section{Instructions:}

- The girls are in a circle and the mentor sings: The ivory statues move here, move there...

- Then the mentor shouts the name of a body part.

- When each part is mentioned, the girls must position themselves in the form of that part of the body.

\section{NAME THE BODY}

\section{Instructions:}

- Form two teams, and each team presents a volunteer

- The mentor gives each group labels with the names of a girl's body parts to be placed on the girl in the correct location.

- The group that finishes first wins.

\section{SONG}

\section{Instructions:}

- Participants form a circle and the mentor starts a song that names the parts of the body that can be seen.

- The girls point to the parts of the body.

- Then the mentor begins to name parts of the body that cannot be seen, so the girls recognize that there are external organs and internal organs.

In this world there are many little girls (3 repetitions)

Who do not know their body (2 repetitions)

Now I am going to tell you

Head, shoulders, knees, and toes

My body moves, moves the way I want.

... say the body part 


\section{ADOLESCENT GIRLS INITIATIVE-KENYA: PROGRAM ADAPTATION FOR LOW-LITERACY MENTORS}

\begin{abstract}
The Adolescent Girls Initiative-Kenya (AGI-K) helped young, vulnerable adolescent girls build social, health, and economic assets. AGI-K tested combinations of interventions in health, violence prevention, wealth creation, and education to determine which package of interventions delivers the most impact and at what cost. The program reached over 6,000 girls ages 11-14 over two years in Kibera, an urban informal settlement in Nairobi, and in rural Wajir, a remote, underdeveloped area in Kenya along the Northeastern border with Somalia.
\end{abstract}

Because of the low literacy rates and variation in experience with facilitation in the remote, rural, underserved AGI-K site of Wajir, Northern Kenya, the Population Council and implementing partners had difficulties recruiting and retaining mentors who had the capacity to facilitate the safe space curriculum. Within about six months of launching the intervention, the program team recognized that they needed to adapt the program for Wajir to cater to low-literacy mentors.

First, they translated the written English Wajir Health and Life Skills and Financial Education curricula into audio scripts, which were then translated into the Somali language. Then they made audio recordings of each session, put the sessions on USBs, and provided each Wajir mentor with a simple radio with a USB port. The cost of each radio and USB was about $\$ 30$ per mentor.

The audio sessions helped mentors to facilitate sessions effectively, even if their literacy levels were low. Beyond addressing the literacy concern, the audio sessions helped open dialogue between mentors and participants about sexual and reproductive health issues that are often avoided in the more reserved community of Wajir. Also, the audio sessions helped standardize the content delivered as the information was fixed on the recording and not up to the individual mentor to decide what to say, or not say, when facilitating sessions.

Although there was still some variation from mentor to mentor during the activities and discussions, the recordings did help make the delivery of information more uniform. Additionally, some adults in the community would listen to the audio sessions after the safe space sessions took place, which helped to dispel some of the myths and suspicion about what the mentors and girls were discussing in the groups.

Although the use of audio sessions was not planned for at the outset of $\mathrm{AGI}-\mathrm{K}$, the innovation turned out to be an effective tool that could be useful in other mentorled community programming.

For more information: Austrian, K., E. Soler-Hampejsek, J. Mumah, B. Kangwana, Y. Wado, B. Abuya, V. Shah, and J. Maluccio. 2018. "Adolescent Girls Initiative-Kenya: Midline Results Report." Nairobi: Population Council. 
CHAPTER 4

Monitoring and evaluation

$\begin{array}{llr}\text { TOOL } & \text { Weekly Monitoring } & \text { Page } 107 \\ \text { TOOL } & \text { Monthly Monitoring } & 108 \\ \text { TOOL } & \text { Coaching Guide } & 109 \\ \text { TOOL } & \text { Observation Checklist } & 113 \\ \text { TOOL } & \text { Evaluation Form from Participants } & 119 \\ \text { TOOL } & \text { Self-Administered Mentor Survey } & \\ & & \end{array}$




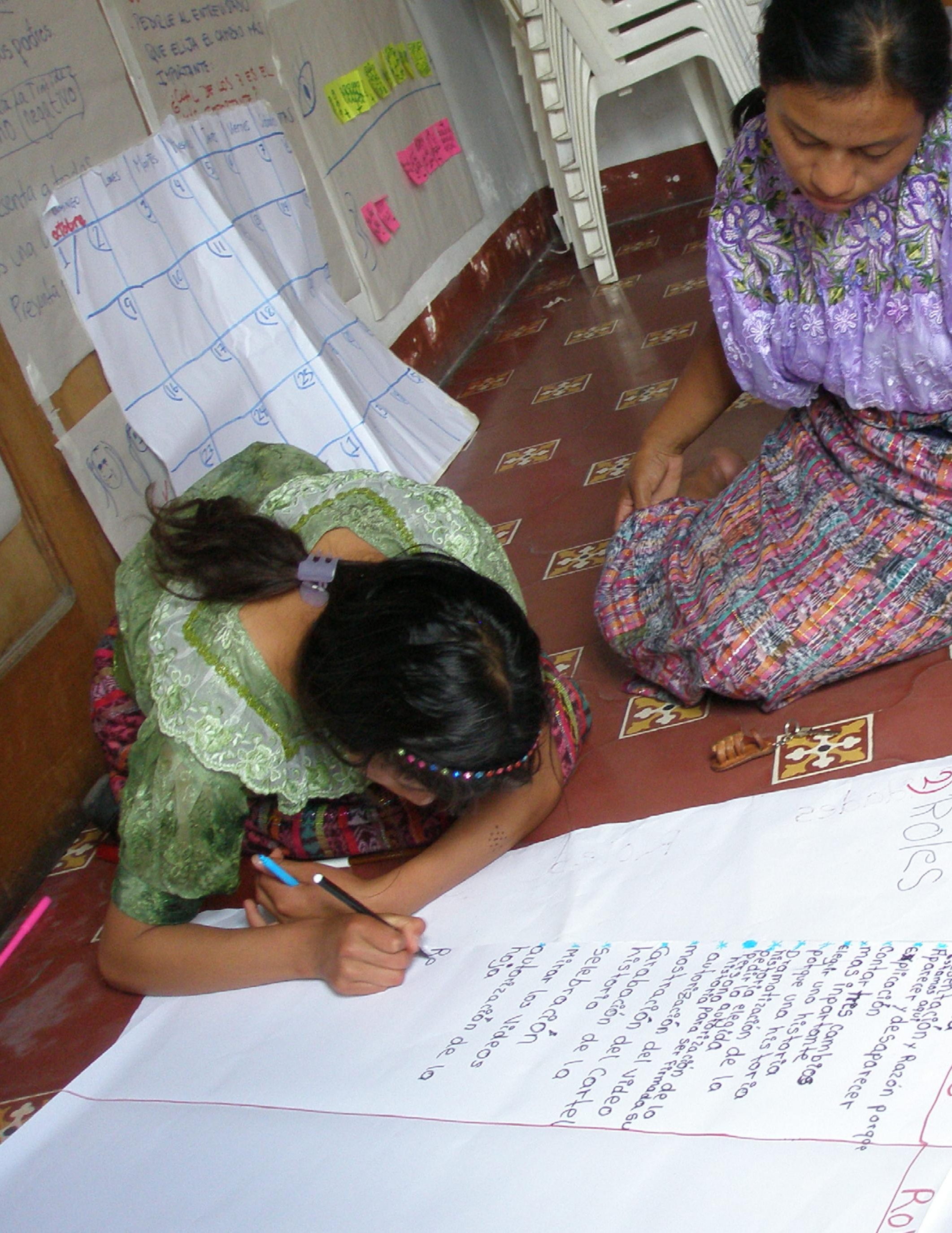




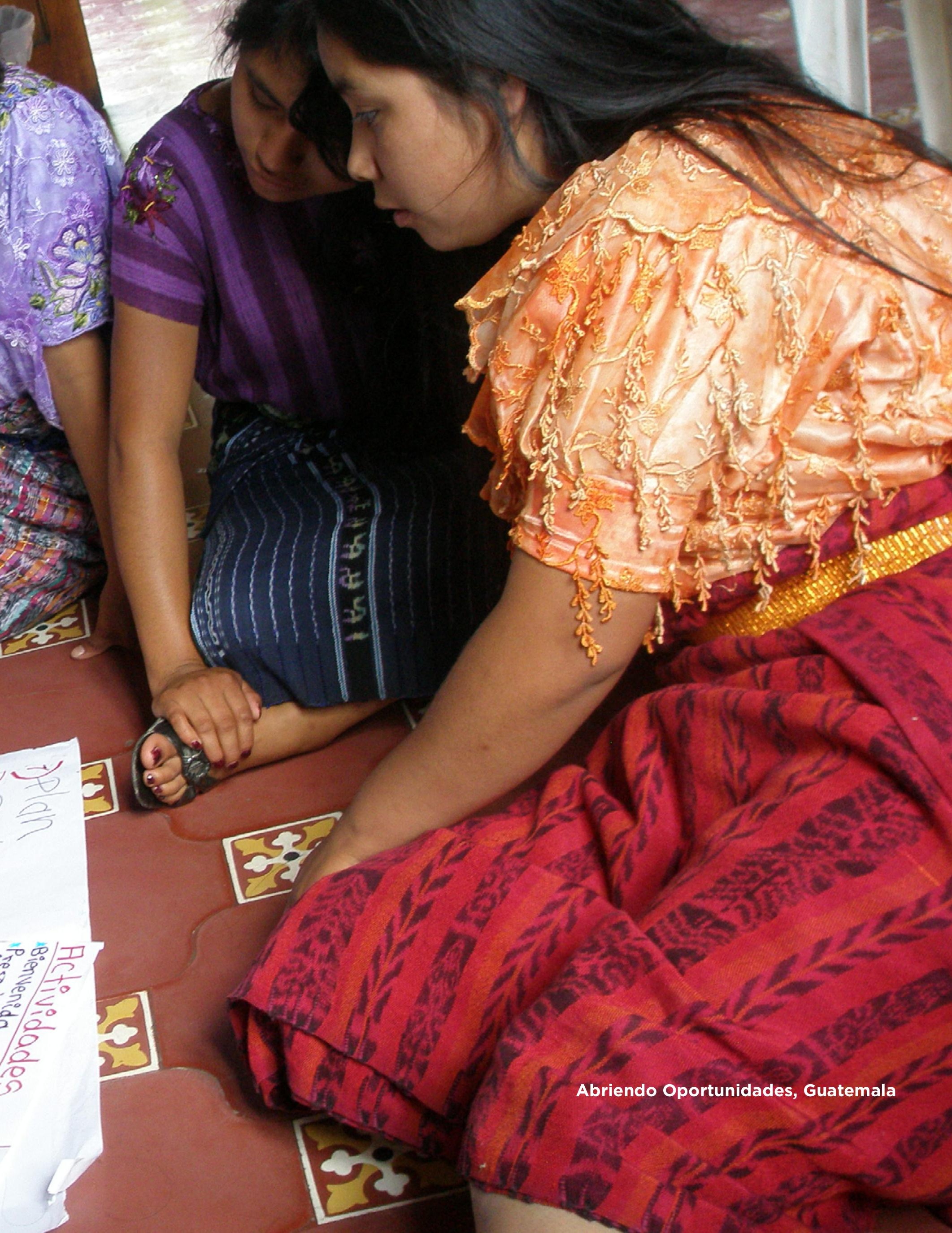


Mentors play a central role in programming, so monitoring and evaluating individual mentors and their support and management systems is essential. While monitoring and evaluation is increasingly accepted as a necessity rather than an optional add-on, it is important also to underscore the empowering nature of the practice. The process of monitoring and evaluation is an important opportunity for mentors to reinforce what is working well and to grow in specific ways in performing their duties.

Mentor monitoring and evaluation takes many forms-from quantitative evaluation to qualitative assessments of processes of change to monthly check-ins with program staff to discuss emergent issues. Some mentors and mentor supervisors use paper forms or visual methods to track attendance, identify who needs extra attention, and other issues; mentors in some programs use mobile-phone-based tools. The tools should use the simplest, most user-friendly method of information collection that aligns with mentors' skills.

Feedback on mentor performance comes from many sourcesincluding fellow mentors, supervisors, outside observers, and girl program participants. A key principle is not to collect more information than the program will use.

While mentors typically serve as the deliverers of programs, the experience of mentoring often enriches their own lives, builds their assets and skills, and may even affect their psychological well-being; in this way, mentors are also program beneficiaries. Some tools included below are examples of ways to evaluate how mentoring changes mentors' lives.

This section includes tools and guides to monitor and support mentors and evaluate performance. 


\section{WEEKLY MONITORING}

This tool can used by mentor supervisors to record whether a meeting was held, data were submitted by each mentor, the relevant session was facilitated, and the curriculum was followed. It can also be used to determine whether a low attendance rate was observed, and whether a high number of nonprogram girls was observed. This provides information mentors can use to follow up with participants to see what is preventing them from attending sessions.

\begin{tabular}{|c|c|c|c|c|c|c|c|c|c|c|}
\hline $\begin{array}{l}\text { WEEK } \\
\text { OF }\end{array}$ & $\begin{array}{l}\text { Mentor } \\
\text { name and } \\
\text { group } \\
\text { number }\end{array}$ & $\begin{array}{l}\text { Meeting data } \\
\text { submitted }\end{array}$ & $\begin{array}{l}\text { Meeting } \\
\text { held }\end{array}$ & $\begin{array}{l}\text { Relevant } \\
\text { session } \\
\text { facilitated }\end{array}$ & $\begin{array}{l}\text { Curriculum } \\
\text { followed }\end{array}$ & $\begin{array}{l}\text { Low atten- } \\
\text { dance rate } \\
\text { observed }\end{array}$ & $\begin{array}{l}\text { High } \\
\text { number of } \\
\text { nonprogram } \\
\text { girls }\end{array}$ & Comments & $\begin{array}{l}\text { Needs } \\
\text { follow-up }\end{array}$ & $\begin{array}{l}\text { Action } \\
\text { taken after } \\
\text { follow-up }\end{array}$ \\
\hline [Date] & & & & & & & & & & \\
\hline [Date] & & & & & & & & & & \\
\hline [Date] & & & & & & & & & & \\
\hline [Date] & & & & & & & & & & \\
\hline [Date] & & & & & & & & & & \\
\hline [Date] & & & & & & & & & & \\
\hline [Date] & & & & & & & & & & \\
\hline [Date] & & & & & & & & & & \\
\hline [Date] & & & & & & & & & & \\
\hline [Date] & & & & & & & & & & \\
\hline [Date] & & & & & & & & & & \\
\hline [Date] & & & & & & & & & & \\
\hline [Date] & & & & & & & & & & \\
\hline [Date] & & & & & & & & & & \\
\hline [Date] & & & & & & & & & & \\
\hline
\end{tabular}




\section{MONTHLY MONITORING}

The tool below is to be completed by mentors and provides an opportunity to reflect on sessions facilitated in the previous month. This tool is from a program that included health vouchers, savings accounts, and a focus on gender-based violence, but other relevant program activities can be substituted as needed.

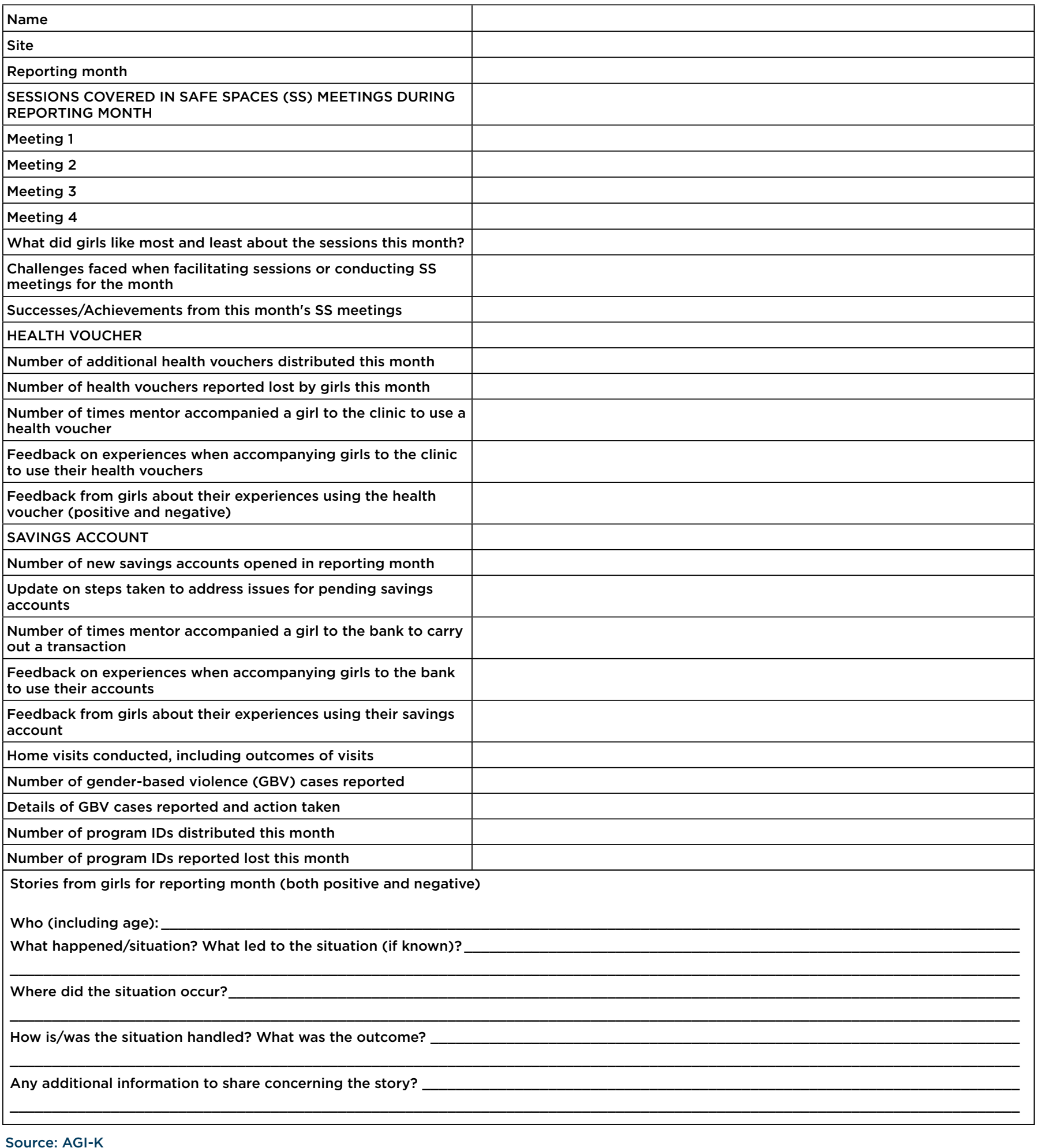




\section{COACHING GUIDE ${ }^{35}$}

Mentor coaching in some programs is done during monthly visits to the mentor's safe space session and offers timely feedback to improve quality. Performance is evaluated through indicators established in the Coaching Guide, followed by a dialogue with the mentor to reflect on the most relevant aspects of the mentor's performance, in a process that offers the opportunity to learn.

The Coaching Guide has four sections that focus on what program participants consider are the program's best assets:

1. Gaining confidence about participating;

2. Increasing self-esteem;

3. Receiving new knowledge; and

4. Expanding network of friends.

Each section is broken down into several indicators that are ranked by the "traffic light system," describing the level of performance by colors: green, yellow, or red.

\section{Before the Visit}

- Confirm date and time of session with the mentor.

- Identify the type of session that will be taking place.

- If it is a topic session, read the activities proposed in the curriculum guide.

- Notify the community mentor that you will visit. (You can also make surprise visits without giving previous notification.)

- If this is not the first time you have visited the mentor, identify her main strengths and weaknesses.

- Fill in the general data in the Coaching Guide form.

\section{During the Visit}

It is important to limit the visit's impact on usual and ongoing activities. When arriving in the community:

- Greet the community mentor and adolescent girls in the community.

- Explain the purpose of the routine visit.

- Strengthen the community mentor's confidence.

\section{During the Session}

- Greet the group of participants and say that you are encouraged to see how they work, play, and talk during the session.

- Take a place within the safe space from which the group and the community mentor are visible, where activities are not interrupted.

- Fill in the Coaching Guide form by marking an X inside the box of the traffic light column that best describes what happened in the session.

- Write notes, suggestions, questions, ideas, and/or congratulations to the mentor in the final column.

- It is not necessary to fill in the form in the order that it is presented. Fill it in according to the moment in which relevant situations occur in the session.

35 https://knowledgecommons.popcouncil.org/departments_sbsr-pgy/593/ 


\section{COACHING GUIDE (continued)}

\section{After the Session}

- Congratulate the mentor by emphasizing a positive aspect of her implementation.

- Develop a dialogue with the mentor based on the Coaching Guide.

- Ask the mentor: What do you find valuable about the session? What did participants achieve? What objectives remain pending?

- Share the results and notes in the Coaching Guide form.

- Agree on strategies to improve the quality of the session, addressing aspects that are weak.

- Acknowledge the openness of the mentor and her willingness to continue supporting adolescent girls, appreciating another positive aspect of her performance.

\section{After the Visit}

It is important to record results in monitoring instruments immediately after the visit so that valuable information is not lost, to identify any gaps that need to be reviewed as soon as possible with the mentor, and to address with the site coordinator any relevant issue that warrants attention.

- Enter results in the appropriate monitoring database.

- Transcribe outstanding comments from the visit.

- File the form in the mentor's records.

- Communicate to the appropriate party any extraordinary situation that requires special attention. 


\begin{tabular}{|l|l|}
\hline Mentor name & \\
\hline Date of the visit & \\
\hline Community visited & \\
\hline Number of participants present in the session & \\
\hline Planned activity for the day & \\
\hline Session start time: & End time: \\
\hline Condition of safe space & \\
\hline
\end{tabular}

\section{The mentor guides the sessions.}

\begin{tabular}{|c|c|c|}
\hline $\begin{array}{l}\text { Gives clear } \\
\text { instructions } \\
\text { and guides the } \\
\text { activities }\end{array}$ & $\begin{array}{l}\text { Green: She assertively said what the group should do and the } \\
\text { participants understood. } \\
\text { Yellow: She said what to do but she got confused and gave } \\
\text { instructions several times. } \\
\text { Red: She did not say what had to be done, the group did not } \\
\text { understand her, and she read the activities directly out of the } \\
\text { curriculum guide. }\end{array}$ & Notes: \\
\hline $\begin{array}{l}\text { Carries out } \\
\text { the necessary } \\
\text { activities } \\
\text { to achieve } \\
\text { objectives }\end{array}$ & $\begin{array}{l}\text { Green: Carried out the necessary activities to achieve the objectives } \\
\text { of the session. } \\
\text { Yellow: Performed some activities, reaching some objectives but } \\
\text { not all. } \\
\text { Red: She did not carry out activities that would lead to the } \\
\text { objectives of the session. }\end{array}$ & \\
\hline $\begin{array}{l}\text { Arrives at the } \\
\text { session with } \\
\text { the necessary } \\
\text { material } \\
\text { prepared }\end{array}$ & $\begin{array}{l}\text { Green: She arrived with all the material prepared for the session. } \\
\text { Yellow: She came with some of the prepared materials, but some } \\
\text { things were missing. } \\
\text { Red: She arrived without material prepared for the session. }\end{array}$ & \\
\hline $\begin{array}{l}\text { Understands } \\
\text { the topic } \\
\text { that is being } \\
\text { worked on }\end{array}$ & $\begin{array}{l}\text { Green: Explained the topic with correct information and was able to } \\
\text { answer questions. } \\
\text { Yellow: Managed some information on the subject but not enough. } \\
\text { Red: Provided the wrong information in relation to the subject and } \\
\text { could not answer questions. }\end{array}$ & \\
\hline \multicolumn{3}{|c|}{ 2. The mentor encourages participation. } \\
\hline $\begin{array}{l}\text { Asks questions } \\
\text { to identify } \\
\text { participants' } \\
\text { previous } \\
\text { knowledge }\end{array}$ & $\begin{array}{l}\text { Green: She asked questions that inspired participants to express } \\
\text { themselves and share their ideas about the subject. } \\
\text { Yellow: The questions she asked did not encourage the participants } \\
\text { to express themselves on the subject. } \\
\text { Red: She did not ask questions about the subject. }\end{array}$ & \\
\hline $\begin{array}{l}\text { Allows } \\
\text { participants to } \\
\text { guide activities } \\
\text { and take } \\
\text { leadership }\end{array}$ & $\begin{array}{l}\text { Green: She allowed participants to lead activities during the session. } \\
\text { Yellow: Adolescent girls participated in activities but they did not } \\
\text { lead activities. } \\
\text { Red: She did not carry out activities where young people could } \\
\text { participate and be leaders. }\end{array}$ & \\
\hline
\end{tabular}




\section{COACHING GUIDE (continued)}

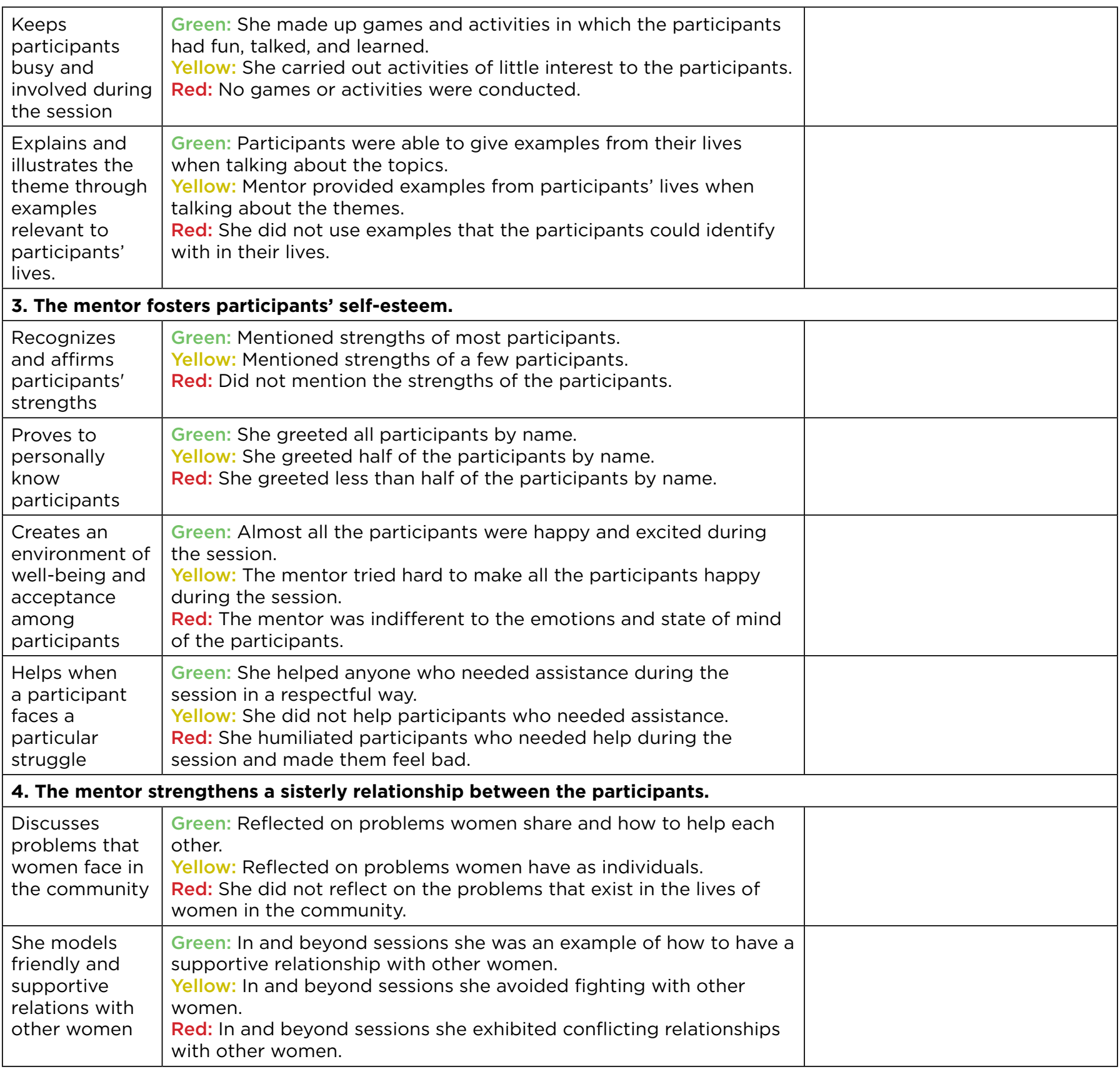




\section{OBSERVATION CHECKLIST}

This tool measures mentor performance on facilitation skills, creation of a supportive environment, communication, relationship building, knowledge, and leadership. Observers (including external research assistants or others) conduct an on-site visit and complete the form, indicating level of competency based on the scoring guide described after the checklist. ${ }^{36}$

Mentor code Site Date of visit

Group number

Planned topic/activity for the day

Session scheduled to begin at

Location of safe space
Number of girls registered to group

Number of girls present

Session began at

Session ended at

Evaluation conducted by

Instructions: Tick the level of competency that best describes the mentor's performance.

\begin{tabular}{|c|c|c|c|c|c|c|}
\hline \multicolumn{2}{|r|}{ Facilitation } & Level 1 & Level 2 & Level 3 & N/A & Notes \\
\hline 1 & Patience & & & & & \\
\hline 2 & Has fun with girls, enthusiastic & & & & & \\
\hline 3 & $\begin{array}{l}\text { Makes use of practical examples relevant } \\
\text { to the girls' lives }\end{array}$ & & & & & \\
\hline 4 & $\begin{array}{l}\text { Is empathetic, caring, and sensitive: } \\
\text { Asks questions in order to identify the } \\
\text { girls' knowledge and experiences on the } \\
\text { session topic }\end{array}$ & & & & & \\
\hline 5 & $\begin{array}{l}\text { Establishing a physical space that is } \\
\text { supportive and conducive to learning }\end{array}$ & & & & & \\
\hline 6 & $\begin{array}{l}\text { Facilitation, Time Management: Makes } \\
\text { use of session guide }\end{array}$ & & & & & \\
\hline 7 & $\begin{array}{l}\text { Preparedness, Time Management: } \\
\text { Mentor reaches established meeting- } \\
\text { session goals by doing all of the } \\
\text { activities }\end{array}$ & & & & & \\
\hline 8 & $\begin{array}{l}\text { Preparedness, Administrative } \\
\text { Management: Mentor comes to the } \\
\text { session prepared }\end{array}$ & & & & & \\
\hline
\end{tabular}




\section{OBSERVATION CHECKLIST (continued)}

Instructions: Tick the level of competency that best describes the mentor's performance.

\begin{tabular}{|c|c|c|c|c|c|c|}
\hline \multicolumn{2}{|c|}{ Supportive environment } & \multirow[t]{2}{*}{ Level 1} & \multirow[t]{2}{*}{ Level 2} & \multirow[t]{2}{*}{ Level 3} & \multirow[t]{2}{*}{ N/A } & \multirow[t]{2}{*}{ Notes } \\
\hline 9 & $\begin{array}{l}\text { Creating an emotionally safe space, } \\
\text { relationship-building: Creates an } \\
\text { atmosphere of well-being and } \\
\text { acceptance among the girls }\end{array}$ & & & & & \\
\hline 10 & $\begin{array}{l}\text { Creating an emotionally safe space, } \\
\text { relationship-building: Proves she knows } \\
\text { the girls personally }\end{array}$ & & & & & \\
\hline 11 & $\begin{array}{l}\text { Creating an emotionally safe space, } \\
\text { nonjudgmental, relationship-building: } \\
\text { Discusses the problems shared by girls } \\
\text { in the group }\end{array}$ & & & & & \\
\hline \multicolumn{2}{|c|}{ Communication } & Level 1 & Level 2 & Level 3 & N/A & Notes \\
\hline 12 & $\begin{array}{l}\text { Communication/Facilitation: Use of } \\
\text { body language to enhance the girls' } \\
\text { engagement }\end{array}$ & & & & & \\
\hline 13 & $\begin{array}{l}\text { Communication/Facilitation: Simplifying } \\
\text { the language for girls' understanding }\end{array}$ & & & & & \\
\hline 14 & $\begin{array}{l}\text { Communication/Facilitation: Provides } \\
\text { clear instructions during the session }\end{array}$ & & & & & \\
\hline 15 & $\begin{array}{l}\text { Communication/Facilitation: Active } \\
\text { listening }\end{array}$ & & & & & \\
\hline \multicolumn{2}{|c|}{ Relationship-building } & Level 1 & Level 2 & Level 3 & N/A & Notes \\
\hline 16 & Anger management & & & & & \\
\hline 17 & Conflict resolution & & & & & \\
\hline 18 & $\begin{array}{l}\text { Teamwork, relationship-building: } \\
\text { Stimulates teamwork among the girls }\end{array}$ & & & & & \\
\hline \multicolumn{2}{|c|}{ Knowledge } & Level 1 & Level 2 & Level 3 & N/A & Notes \\
\hline 19 & $\begin{array}{l}\text { Knowledge: Shows comprehension of } \\
\text { the material }\end{array}$ & & & & & \\
\hline 20 & $\begin{array}{l}\text { Knowledge, Developing Girls' Talents: } \\
\text { Level of girls' comprehension of material }\end{array}$ & & & & & \\
\hline \multicolumn{2}{|c|}{ Leadership } & Level 1 & Level 2 & Level 3 & N/A & Notes \\
\hline 21 & $\begin{array}{l}\text { Promote leadership: Allows girls to } \\
\text { participate, guide activities, and take } \\
\text { leadership roles }\end{array}$ & & & & & \\
\hline
\end{tabular}




\section{Scoring guide}

\begin{tabular}{|c|c|c|c|c|}
\hline & & LEVEL 1 & LEVEL 2 & LEVEL 3 \\
\hline \multicolumn{5}{|c|}{ Facilitation } \\
\hline 1 & Patience & $\begin{array}{l}\text { Mentor does not respond to } \\
\text { the girls' questions and their } \\
\text { pace of working. }\end{array}$ & $\begin{array}{l}\text { Mentor sometimes adjusts to } \\
\text { their pace of working and re- } \\
\text { sponds attentively to the girls' } \\
\text { questions. }\end{array}$ & $\begin{array}{l}\text { Mentor always responds } \\
\text { attentively to the girls' ques- } \\
\text { tions/difficulties and adjusts } \\
\text { to their pace of working, } \\
\text { making them feel good about } \\
\text { themselves. }\end{array}$ \\
\hline 3 & $\begin{array}{l}\text { Makes use of } \\
\text { practical examples } \\
\text { relevant to the } \\
\text { girls' lives }\end{array}$ & $\begin{array}{l}\text { Mentor does not use } \\
\text { examples as she delivers } \\
\text { information. }\end{array}$ & $\begin{array}{l}\text { Mentor provides real-life } \\
\text { examples while discussing the } \\
\text { topic. }\end{array}$ & $\begin{array}{l}\text { Mentor provides real-life } \\
\text { examples and the girls are } \\
\text { able to provide examples } \\
\text { from their own lives while } \\
\text { discussing the topic. }\end{array}$ \\
\hline 5 & $\begin{array}{l}\text { Establishes a } \\
\text { physical space } \\
\text { that is supportive } \\
\text { and conducive to } \\
\text { learning }\end{array}$ & $\begin{array}{l}\text { Mentor made no modifica- } \\
\text { tions to the physical space. }\end{array}$ & $\begin{array}{l}\text { Mentor made minor modifi- } \\
\text { cations to the physical space } \\
\text { - such as re-arranging some } \\
\text { furniture into a conducive } \\
\text { group learning environment. }\end{array}$ & $\begin{array}{l}\text { Mentor fully re-arranged } \\
\text { both the physical space and } \\
\text { his/her physical location, } \\
\text { and made full use of his/her } \\
\text { movement in the space. }\end{array}$ \\
\hline
\end{tabular}




\section{OBSERVATION CHECKLIST (continued)}

\section{Scoring guide}

\begin{tabular}{|c|c|c|c|c|}
\hline 8 & $\begin{array}{l}\text { Preparedness, } \\
\text { Administrative } \\
\text { Management: Men- } \\
\text { tor comes to the } \\
\text { session prepared }\end{array}$ & $\begin{array}{l}\text { Mentor came without ma- } \\
\text { terial to the session and did } \\
\text { not plan the session ahead } \\
\text { of time. }\end{array}$ & $\begin{array}{l}\text { Mentor came with some of } \\
\text { the material and some of the } \\
\text { session planned. }\end{array}$ & $\begin{array}{l}\text { Mentor came with all mate- } \\
\text { rials ready and seemed to } \\
\text { have planned her session in } \\
\text { advance. }\end{array}$ \\
\hline & & LEVEL 1 & LEVEL 2 & LEVEL 3 \\
\hline \multicolumn{5}{|c|}{ Supportive environment } \\
\hline 9 & $\begin{array}{l}\text { Creating an emo- } \\
\text { tionally safe space, } \\
\text { relationship-build- } \\
\text { ing: Creates an } \\
\text { atmosphere of } \\
\text { well-being and } \\
\text { acceptance among } \\
\text { the girls }\end{array}$ & $\begin{array}{l}\text { Mentor completes the ses- } \\
\text { sion without acknowledging } \\
\text { the girls' mood or feelings. }\end{array}$ & $\begin{array}{l}\text { Mentor acknowledges the } \\
\text { girls that lack interest but } \\
\text { does not reach out to them. }\end{array}$ & $\begin{array}{l}\text { Mentor acknowledges girls } \\
\text { who are not interested in the } \\
\text { session and takes action to } \\
\text { get them involved. Majority of } \\
\text { girls are interested in being at } \\
\text { the session and participate in } \\
\text { the activities. }\end{array}$ \\
\hline 10 & $\begin{array}{l}\text { Creating an emo- } \\
\text { tionally safe space, } \\
\text { relationship-build- } \\
\text { ing: Proves she } \\
\text { knows the girls } \\
\text { personally }\end{array}$ & $\begin{array}{l}\text { Mentor says less than half of } \\
\text { the girls' names. }\end{array}$ & $\begin{array}{l}\text { Mentor says at least half of } \\
\text { the girls' names. }\end{array}$ & $\begin{array}{l}\text { Mentor says all of the girls' } \\
\text { names. }\end{array}$ \\
\hline 11 & $\begin{array}{l}\text { Creating an emo- } \\
\text { tionally safe space, } \\
\text { nonjudgmental, } \\
\text { relationship-build- } \\
\text { ing: Discusses the } \\
\text { problems shared } \\
\text { by girls in the } \\
\text { group }\end{array}$ & $\begin{array}{l}\text { Girls do not reflect about } \\
\text { the problems common to } \\
\text { their lives. }\end{array}$ & $\begin{array}{l}\text { Girls reflect on problems they } \\
\text { have as individuals, or that } \\
\text { girls like them have in the } \\
\text { community. }\end{array}$ & $\begin{array}{l}\text { Girls reflect on their problems } \\
\text { as individuals, or of girls in } \\
\text { the community in general, } \\
\text { and share ideas on how to } \\
\text { support each other. }\end{array}$ \\
\hline \multicolumn{5}{|c|}{ Communication } \\
\hline 12 & $\begin{array}{l}\text { Communication/ } \\
\text { Facilitation: Use of } \\
\text { body language to } \\
\text { enhance the girls' } \\
\text { engagement }\end{array}$ & $\begin{array}{l}\text { Mentor made no adjust- } \\
\text { ments to her body language. }\end{array}$ & $\begin{array}{l}\text { Mentor used engaging facial } \\
\text { expressions and modified her } \\
\text { posture. }\end{array}$ & $\begin{array}{l}\text { Mentor adjusted facial } \\
\text { expressions, posture, hand } \\
\text { gestures and tone of voice - } \\
\text { all to enhance girls' } \\
\text { engagement. }\end{array}$ \\
\hline 13 & $\begin{array}{l}\text { Communication/ } \\
\text { Facilitation: Simpli- } \\
\text { fying the language } \\
\text { for girls' under- } \\
\text { standing }\end{array}$ & $\begin{array}{l}\text { Mentor did not attempt to } \\
\text { simplify the language used } \\
\text { in the curriculum. }\end{array}$ & $\begin{array}{l}\text { Mentor sometimes simplified } \\
\text { the language of the curricu- } \\
\text { lum and modified her tone of } \\
\text { voice. }\end{array}$ & $\begin{array}{l}\text { Mentor always simplified the } \\
\text { language of the curriculum } \\
\text { and modified her tone of } \\
\text { voice in order to enhance the } \\
\text { participation of the girls. }\end{array}$ \\
\hline 14 & $\begin{array}{l}\text { Communica- } \\
\text { tion/Facilitation: } \\
\text { Provides clear } \\
\text { instructions during } \\
\text { the session }\end{array}$ & $\begin{array}{l}\text { Mentor did not give clear } \\
\text { instructions and did not } \\
\text { further explain. }\end{array}$ & $\begin{array}{l}\text { Mentor gave confusing } \\
\text { instructions but was able to } \\
\text { make the girls understand at } \\
\text { the end by elaborating. }\end{array}$ & $\begin{array}{l}\text { Mentor assertively guided the } \\
\text { group through activities and } \\
\text { the girls understood. }\end{array}$ \\
\hline 15 & $\begin{array}{l}\text { Communication/ } \\
\text { Facilitation: Active } \\
\text { listening }\end{array}$ & $\begin{array}{l}\text { Mentor did not use any "ac- } \\
\text { tive listening" techniques. }\end{array}$ & $\begin{array}{l}\text { Mentor sometimes used short, } \\
\text { encouraging expressions to } \\
\text { show her good listening, and } \\
\text { summarized the information } \\
\text { learned by the girls. }\end{array}$ & $\begin{array}{l}\text { Mentor consistently used } \\
\text { encouraging expressions to } \\
\text { summarize the topics, asked } \\
\text { questions, and listened } \\
\text { carefully. }\end{array}$ \\
\hline
\end{tabular}




\begin{tabular}{|c|c|c|c|c|}
\hline & & LEVEL 1 & LEVEL 2 & LEVEL 3 \\
\hline \multicolumn{5}{|c|}{ Relationship-building } \\
\hline 16 & $\begin{array}{l}\text { Anger manage- } \\
\text { ment }\end{array}$ & $\begin{array}{l}\text { Mentor responded violently } \\
\text { (verbally or physically) and } \\
\text { humiliated girls. }\end{array}$ & $\begin{array}{l}\text { Mentor was not violent to the } \\
\text { girls but yelled inappropri- } \\
\text { ately or was disrespectful to } \\
\text { them. }\end{array}$ & $\begin{array}{l}\text { Mentor responded in a way } \\
\text { that gained control of the } \\
\text { situation but was respectful } \\
\text { and kept the interest of the } \\
\text { girls in mind. }\end{array}$ \\
\hline 18 & $\begin{array}{l}\text { Teamwork, rela- } \\
\text { tionship-building: } \\
\text { Stimulates } \\
\text { teamwork among } \\
\text { the girls }\end{array}$ & $\begin{array}{l}\text { Mentor promoted unhealthy } \\
\text { competition between girls. }\end{array}$ & $\begin{array}{l}\text { Mentor did not encourage } \\
\text { girls to work together. }\end{array}$ & $\begin{array}{l}\text { Mentor encouraged girls to } \\
\text { work together. }\end{array}$ \\
\hline \multicolumn{5}{|c|}{ Knowledge } \\
\hline 19 & $\begin{array}{l}\text { Knowledge: Shows } \\
\text { comprehension of } \\
\text { the material }\end{array}$ & $\begin{array}{l}\text { Mentor did not understand } \\
\text { the curriculum and could not } \\
\text { answer girls' questions. }\end{array}$ & $\begin{array}{l}\text { Mentor partially understood } \\
\text { the curriculum, and could } \\
\text { answer the most important } \\
\text { questions from the girls. }\end{array}$ & $\begin{array}{l}\text { Mentor completely under- } \\
\text { stood the curriculum, and } \\
\text { was able to deliver infor- } \\
\text { mation and answer girls' } \\
\text { questions. }\end{array}$ \\
\hline 20 & $\begin{array}{l}\text { Knowledge, De- } \\
\text { veloping Girls' Tal- } \\
\text { ents: Level of girls' } \\
\text { comprehension of } \\
\text { material }\end{array}$ & $\begin{array}{l}\text { Girls did not seem to under- } \\
\text { stand the curriculum. }\end{array}$ & $\begin{array}{l}\text { Girls partially understood the } \\
\text { curriculum, and could answer } \\
\text { the most important questions. }\end{array}$ & $\begin{array}{l}\text { Girls completely understood } \\
\text { the curriculum, and were able } \\
\text { to communicate with men- } \\
\text { tors and to answer questions } \\
\text { clearly and accurately. }\end{array}$ \\
\hline
\end{tabular}




\section{EVALUATION FORM FROM PARTICIPANTS}

This tool is to be filled out by program participants to give girls the opportunity to provide feedback on their mentor. It should be made clear that the mentor will not know which girl gave what responses, so girls can respond without fearing it will change their relationship with the mentor.

Site:

Girl's ID:
Mentor name and code: Date of interview:

\begin{tabular}{|c|c|c|c|c|}
\hline Questions & AGREE & DISAGREE & $\begin{array}{l}\text { DON'T } \\
\text { KNOW }\end{array}$ & $\begin{array}{l}\text { NOT } \\
\text { APPLICABLE }\end{array}$ \\
\hline \multicolumn{5}{|l|}{ My mentor sometimes gets angry at girls in the group. } \\
\hline \multicolumn{5}{|l|}{ My mentor always makes time to answer all the girls' questions. } \\
\hline \multicolumn{5}{|l|}{$\begin{array}{l}\text { When I arrive at safe space meetings, my mentor is usually } \\
\text { already there. }\end{array}$} \\
\hline \multicolumn{5}{|l|}{ I would like to be like my mentor when I am older. } \\
\hline \multicolumn{5}{|l|}{ My mentor is not respected in the community. } \\
\hline \multicolumn{5}{|l|}{ I don't trust my mentor. } \\
\hline \multicolumn{5}{|l|}{ My mentor makes it easy for all girls in the group to participate. } \\
\hline \multicolumn{5}{|l|}{ My safe space meetings are fun. } \\
\hline \multicolumn{5}{|l|}{ We play educational games during group sessions. } \\
\hline \multicolumn{5}{|l|}{$\begin{array}{l}\text { Sometimes we break up into small groups to discuss topics } \\
\text { during safe space meetings. }\end{array}$} \\
\hline \multicolumn{5}{|l|}{ My mentor always calls on the same girls to participate. } \\
\hline \multicolumn{5}{|l|}{$\begin{array}{l}\text { My safe space group is a place where the girls feel free to ask all } \\
\text { kinds of questions. }\end{array}$} \\
\hline \multicolumn{5}{|l|}{$\begin{array}{l}\text { If I had a problem, my mentor is one of the first people I would } \\
\text { tell. }\end{array}$} \\
\hline \multicolumn{5}{|l|}{$\begin{array}{l}\text { When there are problems between girls in the safe space group, } \\
\text { my mentor helps them to work it out. }\end{array}$} \\
\hline \multicolumn{5}{|l|}{$\begin{array}{l}\text { My mentor comes to find me after I miss a few safe space } \\
\text { meetings. }\end{array}$} \\
\hline \multicolumn{5}{|l|}{$\begin{array}{l}\text { When there are issues with parents, my mentor is usually able to } \\
\text { help solve them. }\end{array}$} \\
\hline \multicolumn{5}{|l|}{$\begin{array}{l}\text { My mentor can usually answer questions about the topics she's } \\
\text { teaching. }\end{array}$} \\
\hline \multicolumn{5}{|l|}{$\begin{array}{l}\text { When girls ask personal questions in the group, other girls make } \\
\text { fun of them. }\end{array}$} \\
\hline \multicolumn{5}{|l|}{ My mentor likes some girls in our group more than others. } \\
\hline \multicolumn{5}{|l|}{ My mentor says that family planning is only for married girls. } \\
\hline $\begin{array}{l}\text { If I told my mentor something private she would tell someone } \\
\text { else. }\end{array}$ & & & & \\
\hline
\end{tabular}




\section{SELF-ADMINISTERED MENTOR SURVEY}

This survey, to be completed by mentors, includes basic demographic information, mentor time and money required to attend sessions, information about other paid work done by the mentor, asset ownership, financial education questions, HIV and sexual and reproductive health knowledge assessment, gender attitudes, selfefficacy questions, information about frequency of activities associated with mentoring like home visits and referrals, assessments of personal gains from mentoring, and assessment of the experience of being a mentor. This tool can be completed by mentors during a mentor refresher training (midway through the program), and again at the second-to-last mentor meeting before sites close, so changes in values and knowledge can be assessed.

Site:

Date of interview:

Mentor code:

\begin{tabular}{|c|c|}
\hline Question & Answer \\
\hline \multicolumn{2}{|l|}{ What is your age? } \\
\hline \multicolumn{2}{|l|}{ What is your religion? } \\
\hline What is your level of education? & $\begin{array}{l}\text { No education } \\
\text { Primary incomplete } \\
\text { Primary complete } \\
\text { Secondary incomplete } \\
\text { Secondary complete } \\
\text { Higher diploma } \\
\text { University } \\
\text { Trade/vocational school } \\
\end{array}$ \\
\hline What is your marital status? & $\begin{array}{l}\text { Currently married } \\
\text { Currently living with a boyfriend } \\
\text { Divorced } \\
\text { Separated } \\
\text { Widowed } \\
\text { Never married }\end{array}$ \\
\hline \multicolumn{2}{|l|}{$\begin{array}{l}\text { If you've ever been married, at what age did you get } \\
\text { married the first time? }\end{array}$} \\
\hline \multicolumn{2}{|l|}{$\begin{array}{l}\text { How many living biological children do you have? } \\
\text { [Write '0O' if no children] }\end{array}$} \\
\hline $\begin{array}{l}\text { Write down the ages of your living biological } \\
\text { children, starting with the oldest }\end{array}$ & $\begin{array}{l}\text { Child } 1: \\
\text { Child } 2:- \\
\text { Child } 3:- \\
\text { Child } 4:- \\
\text { Child } 5:- \\
\quad \text { No children } \\
\end{array}$ \\
\hline How old were you the first time you got pregnant? & Age: $\_$Never been pregnant \\
\hline What ethnic group do you belong to? & \\
\hline
\end{tabular}




\section{SELF-ADMINISTERED MENTOR SURVEY (continued)}

\begin{tabular}{|c|c|}
\hline Question & Answer \\
\hline \multicolumn{2}{|l|}{ What languages do you speak? } \\
\hline \multicolumn{2}{|l|}{$\begin{array}{l}\text { What are the main languages you use in your safe } \\
\text { spaces group? }\end{array}$} \\
\hline $\begin{array}{l}\text { How long does it typically take you to get to your } \\
\text { safe spaces group meeting? }\end{array}$ & $\begin{array}{l}\text { Less than } 15 \text { minutes } \\
16-30 \text { minutes } \\
\text { 31-60 minutes } \\
\text { More than } 1 \text { hour }\end{array}$ \\
\hline $\begin{array}{l}\text { What means do you usually use to get to your safe } \\
\text { spaces meeting? }\end{array}$ & $\begin{array}{l}\text { Walking } \\
\text { Public transport } \\
\text { Ride my bicycle } \\
\text { Other: }\end{array}$ \\
\hline $\begin{array}{l}\text { On average, how much money do you spend each } \\
\text { week to get to your safe spaces meeting? }\end{array}$ & $\begin{array}{l}\text { Amount: } \\
\text { No money }\end{array}$ \\
\hline $\begin{array}{l}\text { On average, how much do you spend of your own } \\
\text { money (beyond what is given to you to cover trans- } \\
\text { port costs) to get to program activities that are not } \\
\text { safe spaces meetings? }\end{array}$ & $\begin{array}{l}\text { Amount: } \\
\text { No money }\end{array}$ \\
\hline $\begin{array}{l}\text { As you know, some people take up jobs for which } \\
\text { they are paid in cash or kind. Others sell things, have } \\
\text { a small business, or work on the family farm or in } \\
\text { the family business. In the last seven days, have you } \\
\text { done any of these things or any other work? }\end{array}$ & YES \\
\hline $\begin{array}{l}\text { Aside from your housework, and your work as a } \\
\text { mentor, have you done any work or activities for pay, } \\
\text { either cash or in kind, in the last } 12 \text { months? }\end{array}$ & $\begin{array}{l}\text { YES } \\
\text { NO }\end{array}$ \\
\hline \multicolumn{2}{|l|}{ What type of paid work did you mainly do? } \\
\hline $\begin{array}{l}\text { Were you hired staff, was it a temporary job, or were } \\
\text { you running your own business? }\end{array}$ & $\begin{array}{l}\text { Hired staff } \\
\text { Temporary job } \\
\text { Running own business }\end{array}$ \\
\hline $\begin{array}{l}\text { Have you ever done work either for pay or as a } \\
\text { volunteer in any of the following areas? } \\
\text { For each one, please tick either "No" or "Yes." If } \\
\text { "Yes," please also tick if you received a certificate. }\end{array}$ & 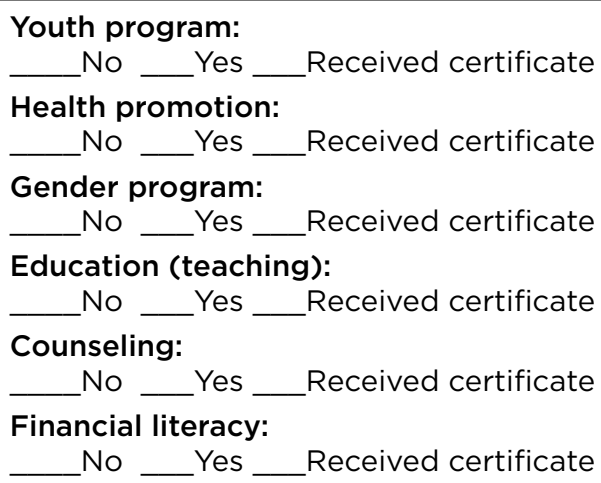 \\
\hline
\end{tabular}




\begin{tabular}{|c|c|}
\hline Question & Answer \\
\hline $\begin{array}{l}\text { If you weren't a mentor, what would you be doing } \\
\text { with that time instead? }\end{array}$ & $\begin{array}{l}\text { Something that earned money } \\
\text { Something that did not earn any money }\end{array}$ \\
\hline $\begin{array}{l}\text { In the last six months, have you suffered a major } \\
\text { illness or had problems with your health that had } \\
\text { a negative effect on your ability to earn money or } \\
\text { complete your usual responsibilities? }\end{array}$ & $\underset{\text { YES }}{-\mathrm{NO}}$ \\
\hline $\begin{array}{l}\text { For each of the items, please tick YES if you own the } \\
\text { item, and NO if you do not }\end{array}$ & 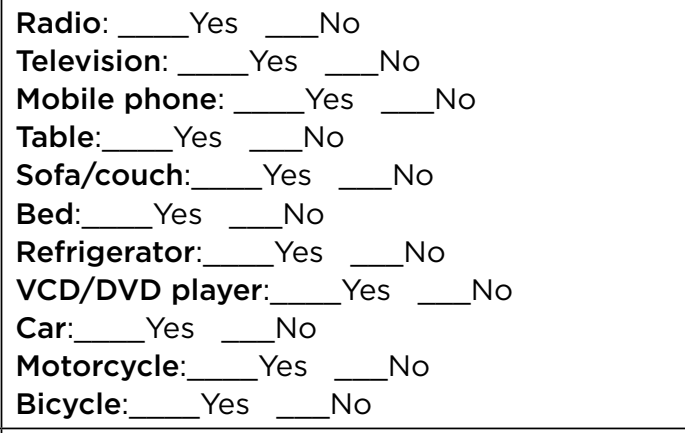 \\
\hline $\begin{array}{l}\text { Mary needs } \$ 2,000 \text { to start a business. She has } \\
\$ 1,000 \text { in her account that she can use for the } \\
\text { business. How much more money does Mary need to } \\
\text { save to be able to start her business? }\end{array}$ & \\
\hline $\begin{array}{l}\text { Grace needs } \$ 1,600 \text { to buy a mobile phone. She } \\
\text { earns an income of } \$ 300 \text { per month. Of that amount, } \\
\text { she is able to save } \$ 200 \text { per month. How many } \\
\text { months would it take Grace to save enough money } \\
\text { to buy the phone? }\end{array}$ & \\
\hline $\begin{array}{l}\text { After Grace has been saving } \$ 200 \text { each month for } \\
\text { three months, she has an emergency that forces } \\
\text { her to use } \$ 400 \text { from her savings. How much more } \\
\text { money does she need to save to reach her goal of } \\
\$ 1,600 \text { ? }\end{array}$ & \\
\hline \multicolumn{2}{|c|}{$\begin{array}{l}\text { Now we would like to ask you some questions about HIV/AIDS and other reproductive health issues } \\
\text { For each statement, please tick whether you "Agree" or "Disagree." }\end{array}$} \\
\hline $\begin{array}{l}\text { Pregnant women with HIV can take medicine to } \\
\text { prevent their babies from getting HIV. }\end{array}$ & _Agree _ Disagree \\
\hline A healthy-looking person can be infected with HIV. & Disagree \\
\hline $\begin{array}{l}\text { There is currently no medication for HIV-positive } \\
\text { people to extend their lives and improve their quality } \\
\text { of life. }\end{array}$ & __ Agree __ Disagree \\
\hline $\begin{array}{l}\text { If one has other sexually transmitted infections, it } \\
\text { increases one's chance of getting HIV. }\end{array}$ & __ Agree __Disagree \\
\hline
\end{tabular}




\section{SELF-ADMINISTERED MENTOR SURVEY (continued)}

\begin{tabular}{|c|c|}
\hline Question & Answer \\
\hline $\begin{array}{l}\text { Please list all the ways you know that people can } \\
\text { protect themselves from getting infected with HIV. }\end{array}$ & \\
\hline $\begin{array}{l}\text { Please list all of various contraceptive/family } \\
\text { planning methods that a couple can use to delay or } \\
\text { avoid a pregnancy. }\end{array}$ & \\
\hline $\begin{array}{l}\text { Below are some statements about contraceptives. I w } \\
\text { statement. For each statement, please tick whether y }\end{array}$ & $\begin{array}{l}\text { uld like you to tell me if you } \\
\text { u "Agree" or "Disagree." }\end{array}$ \\
\hline A condom can help prevent pregnancy but not HIV. & Agree __ Disagree \\
\hline $\begin{array}{l}\text { Using two condoms at the same time is better than } \\
\text { using just one. }\end{array}$ & _ Agree __ Disagree \\
\hline $\begin{array}{l}\text { Most girls who use contraceptives have many sexual } \\
\text { partners. }\end{array}$ & _ Agree __ Disagree \\
\hline Condoms decrease intimacy or emotional closeness. & _Agree ___Disagree \\
\hline $\begin{array}{l}\text { Condoms are effective in preventing STI } \\
\text { transmission. }\end{array}$ & _ Agree __ Disagree \\
\hline $\begin{array}{l}\text { I would refuse to have sex with someone who is not } \\
\text { prepared to use a condom. }\end{array}$ & __ Agree __ Disagree \\
\hline Condoms should not be reused. & Disagree \\
\hline $\begin{array}{l}\text { Only married girls should have access to } \\
\text { contraceptives. }\end{array}$ & _ Agree __ Disagree \\
\hline Moral people can use condoms. & Agree __ Disagree \\
\hline My religion forbids use of contraceptives. & _Agree __Disagree \\
\hline $\begin{array}{l}\text { Please list the signs and symptoms that might } \\
\text { indicate that a WOMAN has an STI. }\end{array}$ & \\
\hline $\begin{array}{l}\text { Please list the signs and symptoms that might } \\
\text { indicate that a MAN has an STI. }\end{array}$ & \\
\hline
\end{tabular}




\begin{tabular}{|c|c|}
\hline $\begin{array}{l}\text { Which of the following is NOT considered a basic } \\
\text { human right for adolescent girls? }\end{array}$ & $\begin{array}{l}\text { Food } \\
\text { Sanitary towels } \\
\text { Education } \\
\text { Shelter }\end{array}$ \\
\hline $\begin{array}{l}\text { Name three topics included in the life-skills training } \\
\text { for young people. }\end{array}$ & $\begin{array}{l}\text { 1. } \\
\text { 3. } \\
\text { D. Don't know }\end{array}$ \\
\hline $\begin{array}{l}\text { According to the recommended guidelines, what is } \\
\text { the minimum amount of time that a mother should } \\
\text { exclusively breastfeed a child? }\end{array}$ & $\begin{array}{l}2 \text { months } \\
6 \text { months } \\
11 \text { months } \\
1 \text { year } \\
2 \text { years }\end{array}$ \\
\hline $\begin{array}{l}\text { Anemia is a condition that can affect adolescent girls } \\
\text { if they are lacking which of these nutrients in their } \\
\text { body? }\end{array}$ & $\begin{array}{l}\text { Vitamin C } \\
\text { Calcium } \\
\text { Iron } \\
\text { Potassium }\end{array}$ \\
\hline What are two parts of a savings plan? & 1. \\
\hline What are two sections of a budget? & 1. \\
\hline $\begin{array}{l}\text { When someone takes out a loan, what are two of her } \\
\text { responsibilities? }\end{array}$ & 2. \\
\hline What is one INFORMAL way to save money? & \\
\hline What is one FORMAL way to save money? & \\
\hline Do you have a bank account? & Yes _No \\
\hline $\begin{array}{l}\text { Do you have a budget for your personal income and } \\
\text { expenses? }\end{array}$ & Yes ${ }^{\text {No }}$ \\
\hline $\begin{array}{l}\text { Do you have someone that you can talk to when } \\
\text { you're having a personal problem or emergency? }\end{array}$ & Y Yes _ No \\
\hline $\begin{array}{l}\text { What is the legal age of marriage for women in your } \\
\text { country? }\end{array}$ & \\
\hline
\end{tabular}




\section{SELF-ADMINISTERED MENTOR SURVEY (continued)}

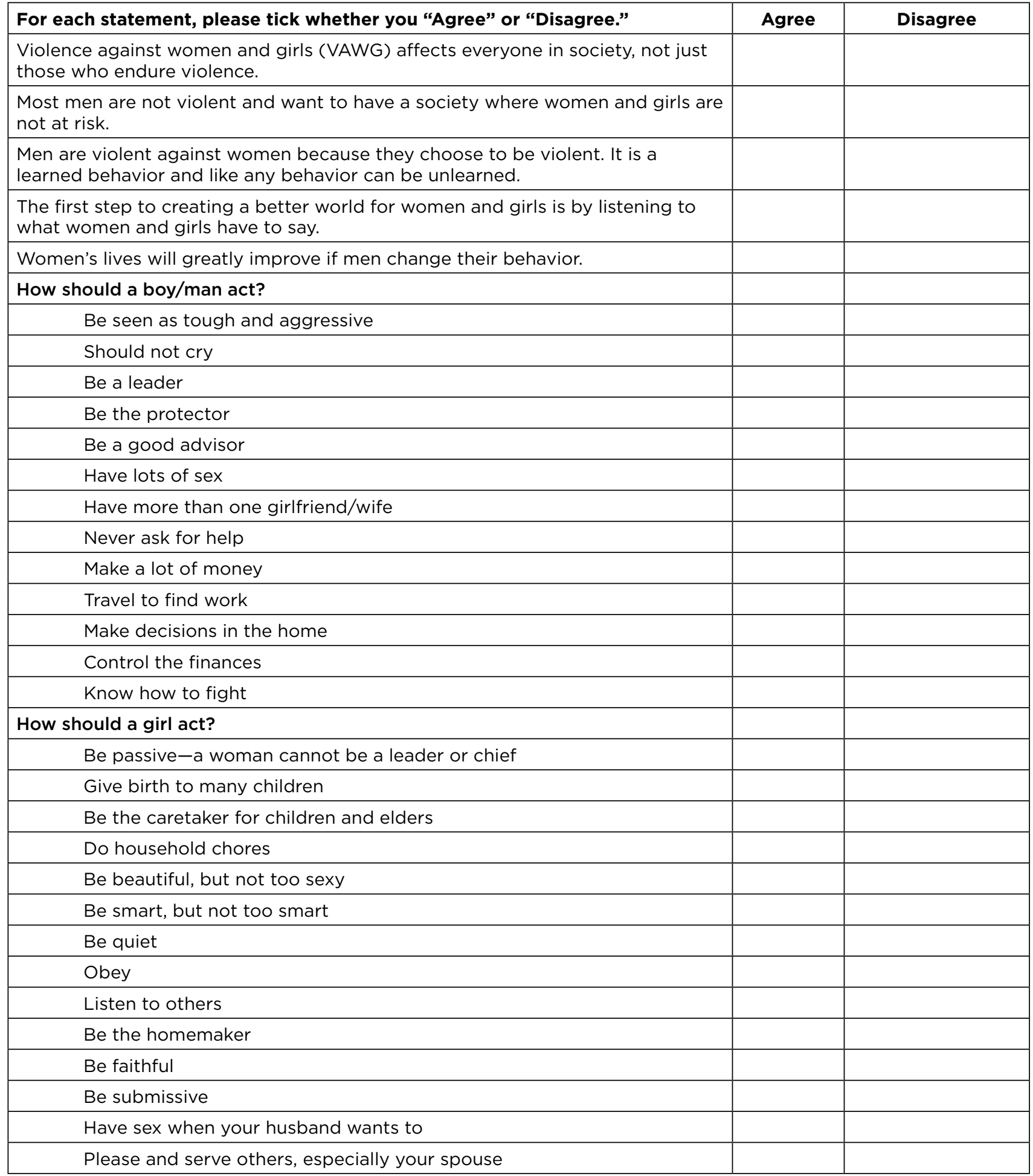




\begin{tabular}{|c|c|c|}
\hline $\begin{array}{l}\text { Here are some of the statements about gender-based violence (GBV). For } \\
\text { each statement, please tick whether the statement is "Fact" or "Myth. }\end{array}$ & Fact & Myth \\
\hline \multicolumn{3}{|l|}{$\begin{array}{l}\text { Women allow intimate partner violence to happen to them, and if they really } \\
\text { want to they can leave their abusive partners. }\end{array}$} \\
\hline \multicolumn{3}{|l|}{ Conflicts are a normal part of any relationship. } \\
\hline \multicolumn{3}{|l|}{ Domestic violence happens only to a certain type of person. } \\
\hline \multicolumn{3}{|l|}{$\begin{array}{l}\text { GBV only includes physical abuse (hitting, punching, biting, slapping, pushing, } \\
\text { etc.). }\end{array}$} \\
\hline \multicolumn{3}{|l|}{ Women should tolerate violence to keep the family together. } \\
\hline \multicolumn{3}{|l|}{$\begin{array}{l}\text { Domestic violence is a private family matter in which the state has no right to } \\
\text { intervene. How a man treats his wife is a private matter. }\end{array}$} \\
\hline \multicolumn{3}{|l|}{ A man cannot rape his wife. } \\
\hline \multicolumn{3}{|l|}{ Most GBV is perpetrated by strangers. } \\
\hline Question & & \\
\hline \multicolumn{3}{|l|}{$\begin{array}{l}\text { Each week, how many minutes in total do you spend preparing for your safe } \\
\text { space meeting? }\end{array}$} \\
\hline \multicolumn{3}{|l|}{$\begin{array}{l}\text { As a mentor, in the last one month how many times did you do any of the } \\
\text { following? For each activity, please tick only one answer, either: every day, a } \\
\text { few times a week, once a week, a few times a month, once a month, or never. }\end{array}$} \\
\hline Visit a girl at her home due to missing meetings & \multicolumn{2}{|c|}{$\begin{array}{l}\text { Every day } \\
\text { A few days a week } \\
\text { Once a week } \\
\text { A few times a month } \\
\text { Once a month } \\
\text { Never }\end{array}$} \\
\hline Counsel a girl regarding a personal problem & \multicolumn{2}{|c|}{$\begin{array}{l}\text { Every day } \\
\text { A few days a week } \\
\text { Once a week } \\
\text { A few times a month } \\
\text { Once a month } \\
\text { Never }\end{array}$} \\
\hline Meet with community leaders to discuss the program & \multicolumn{2}{|c|}{$\begin{array}{l}\text { Every day } \\
\text { A few days a week } \\
\text { Once a week } \\
\text { A few times a month } \\
\text { Once a month } \\
\text { Never }\end{array}$} \\
\hline Refer a girl to another organization for additional support & \multicolumn{2}{|c|}{$\begin{array}{l}\text { Every day } \\
\text { A few days a week } \\
\text { Once a week } \\
\text { A few times a month } \\
\text { Once a month } \\
\text { Never }\end{array}$} \\
\hline Refer a girl to obtain contraceptives & \multicolumn{2}{|c|}{$\begin{array}{l}\text { Every day } \\
\text { A few days a week } \\
\text { Once a week } \\
\text { A few times a month } \\
\text { Once a month } \\
\text { Never }\end{array}$} \\
\hline
\end{tabular}




\section{SELF-ADMINISTERED MENTOR SURVEY (continued)}

\begin{tabular}{|c|c|}
\hline QUESTION & ANSWER \\
\hline \multicolumn{2}{|c|}{$\begin{array}{l}\text { After how many missed meetings in a row are you supposed to visit a girl at } \\
\text { her home? }\end{array}$} \\
\hline \multicolumn{2}{|l|}{ For how many years will the program last? } \\
\hline \multicolumn{2}{|c|}{$\begin{array}{l}\text { For each of the following topics, please think about how much you have learned/gained in this area as part of } \\
\text { the program trainings and being a mentor. Please indicate if you have learned/gained a lot, a little bit, or } \\
\text { nothing at all. }\end{array}$} \\
\hline Leadership & $\begin{array}{l}\text { Learned/gained a lot } \\
\text { Learned/gained a little bit } \\
\text { Learned/gained nothing }\end{array}$ \\
\hline Mentorship & $\begin{array}{l}\text { Learned/gained a lot } \\
\text { Learned/gained a little bit } \\
\text { Learned/gained nothing }\end{array}$ \\
\hline Knowledge of reproductive health & $\begin{array}{l}\text { Learned/gained a lot } \\
\text { Learned/gained a little bit } \\
\text { Learned/gained nothing }\end{array}$ \\
\hline Knowledge of nutrition & $\begin{array}{l}\text { Learned/gained a lot } \\
\text { Learned/gained a little bit } \\
\text { Learned/gained nothing }\end{array}$ \\
\hline Knowledge of financial literacy & $\begin{array}{l}\text { Learned/gained a lot } \\
\text { Learned/gained a little bit } \\
\text { Learned/gained nothing }\end{array}$ \\
\hline Personal self-esteem/confidence & $\begin{array}{l}\text { Learned/gained a lot } \\
\text { Learned/gained a little bit } \\
\text { Learned/gained nothing }\end{array}$ \\
\hline \multicolumn{2}{|c|}{$\begin{array}{l}\text { For each of the following, please think about your role as a mentor and tick whether you agree or disagree with } \\
\text { the following statements. }\end{array}$} \\
\hline Being a mentor is fun. & _Agree ___Disagree \\
\hline Being a mentor is a lot of work. & _Agree __Disagree \\
\hline It is personally rewarding to be a mentor. & Agree \\
\hline It is rewarding for the girls to be a part of the program. & Agree \\
\hline
\end{tabular}


CHAPTER 5

Models of sustainability

CASE STUDY Biruh Tesfa: Government Ownership and Sustainability of Girl-Centered Programming in Ethiopia

Page 129

CASE STUDY Abriendo Oportunidades: A Sustainable Structure Via Mentor Self-Governed NGOs 
What comes next for mentors after the program ends?

Mentors should be prepared from the beginning for their mentor role to end. Being a girls' group mentor is not a permanent position because mentors only meet the age requirements for a few years. This doesn't mean the program ends; it means that programs should plan from the beginning what will take place when mentors no longer meet the age requirements of the program and how new mentors will be recruited to replace them. While some mentors go on through a system of cascading leadership to become program staff, regional coordinators, or mentor trainers, others use their skills in the community in other ways, such as becoming leaders and organizers. In this way, training local mentors creates a resource to benefit the community after their tenure in the girls' program is over.

The cascading leadership model also means that girls who recently completed the program are now a pool of potential mentors. Finding enthusiastic, promising girls within the group of program graduates who could be mentors themselves can save on recruitment and training costs and time, since they will be familiar with the structure and themes of the program. Some programs use recent program graduates as junior mentors who assist older mentors with the program as a way of preparing them to lead their own groups.

This section provides two case studies describing sustainability models. 


\section{BIRUH TESFA: GOVERNMENT OWNERSHIP AND SUSTAINABILITY OF GIRL-CENTERED PROGRAMMING IN ETHIOPIA}

\author{
Biruh Tesfa ("Bright Future") was \\ a program for out-of-school girls \\ and young women aged 7 to 24 in \\ urban Ethiopia. Girls came together \\ in group meetings five days a \\ week for two hours a day with \\ adult female mentors and received \\ basic literacy, life skills, financial \\ literacy and savings, and sexual and \\ reproductive health education. The \\ program reached over 75,000 girls. \\ The Population Council worked \\ closely with the Ministry of Women, \\ Children and Youth Affairs at the \\ national, regional, and kebele (local \\ administration) level to conduct a \\ formative assessment and design, \\ pilot, manage, and monitor the \\ program.
}

Government engagement and ownership was an essential factor in Biruh Tesfa's successful implementation. From the beginning, the Ethiopian government was directly involved in running the program, ensuring it aligned to policies and that interventions reached vulnerable girls. The government provided office space for Council staff, which facilitated government buy-in and coordination. Together, they managed mentor recruitment, training, and monitoring; mentors were recruited from the local community, trained, and paid the equivalent of a government Alternative Basic Education (ABE) facilitator. The government provided meeting spaces for the girls' weekly meetings, which helped with sustainable costsharing.

The Women Empowerment and Participation Directorate at the ministry appointed someone to be a focal point in each kebele, and this individual became the government's ambassador for Biruh Tesfa. Each month, this individual led monthly mentors' meetings and submitted a performance report.

The Ethiopian government truly owned the program, which boosted local capacity to design, manage, and monitor scalable girl-centered programming. After mentors' roles in Biruh Tesfa ended, government offices absorbed many of them into government-led ABE programming and other community-development work. Local NGOs doing girl-focused work hired other mentors.

For more information: Erulkar, Annabel. 2014. "Building the assets to thrive: Addressing the HIV-related vulnerabilities of adolescent girls in Ethiopia." New York: Population Council. https:// knowledgecommons.popcouncil.org/departments_sbsr-pgy/580/. 


\section{ABRIENDO OPORTUNIDADES: A SUSTAINABLE STRUCTURE VIA MENTOR SELF-GOVERNED NGOS}

\begin{abstract}
Abriendo Oportunidades ("Opening Opportunities") makes critical investments in rural, indigenous girls aged 8-19 in Guatemala to help them successfully navigate adolescent transitions by building social support networks, connecting them with role models and mentors, building a base of life and leadership skills, and engaging the community to create awareness about girls' rights and needs. AO mentors are young women aged $18-25$ years who live in the same communities as girl groups.
\end{abstract}

After completing the AO program in Totonicapán in the Western Highlands of Guatemala, the Population Council guided AO community mentors, who were former AO participants, to explore the possibility of creating a nongovernmental organization (NGO). In 2013, 15 AO mentors created REDMI Ak'ab'al (“Indigenous Women's Network Abriendo Oportunidades"). REDMI implements AO girl groups as part of the larger AO program, receiving a subaward from the Council to do the work, in addition to running girl groups independent of Council programming. REDMI also has an income-generating program where members produce crafts to sell and support girl group activities.

In 2016-2017, a group of AO mentors from Chisec Alta Verapaz in the northeast region of Guatemala formed the organization Red Na'leb'Ak ("Knowledge generated collectively"). The organization was started by $18 \mathrm{AO}$ mentors, and it has grown to a 25 -member organization. Following the AO model, Red Na'leb'Ak facilitates 12 girl groups in the community. The NGO wrote a proposal to fund activities to strengthen their collaboration and coordination with the local government. Red Na'leb'Ak also is taking steps to address nutrition in their community, working with another NGO, SANK, to create family gardens with endemic plants that are highly nutritious.
The Population Council helped establish both organizations with legal and financial counsel, advice on the best type of NGO to establish given varying requirements for fundraising and government accountability for each NGO category in Guatemala. With fundraising support from the Population Council, both organizations have received funding from private donors and international NGOs.

The NGO platform has allowed the AO mentors to grow personally and professionally as young women. The formation of these NGOs enabled mentors to expand their facilitation and leadership skills, develop their community-advocacy skills, strengthen their social support networks, enhance their exposure to professional opportunities in their communities, delay marriage, and avoid migration.

For more information: Abriendo Oportunidades ("Opening Opportunities"), https://www.popcouncil.org/research/ abriendo-oportunidades-opening-opportunities. Girls Not Brides Case Studies, https://www.girlsnotbrides.org/theory-ofchange/\#casestudies-opening-opportunities. 


\section{Appendices}

1. Frequently Asked Questions

Page 132

2. Population Council Program Descriptions

3. Links to Full Curricula from Programs Included in Mentor Toolkit

4. Additional Resources and Readings 


\section{APPENDIX 1. FREQUENTLY ASKED QUESTIONS}

We surveyed Population Council staff around the world who manage mentor-led girl programming and asked them to provide frequently asked questions. These questions and their responses are below.

\section{Pay}

\section{Why do you pay mentors?}

Because we are asking them to do a job and it is not realistic, nor reasonable, to expect regular, quality participation from someone who is volunteering their time. You must pay mentors to get a quality commitment to the program. Salary is a motivator for mentors to do well. Also, it helps mentors overcome pressure they may feel to get married or engage in unsafe work to support their families.

\section{How do you decide how much to pay?}

Mentors should be paid a comparable salary package to positions with similar requirements and duties in the market locally such as a community health worker.

\section{Do all mentors get the same pay?}

Mentors who do the same tasks get the same pay. In some cases, mentors who take on more groups than usual or who do extra tasks earn increased pay. Mentors may receive a raise after completing a year of mentoring. Whether or not mentors should expect to receive pay increases can be part of the mentor contract.

\section{What else can you give mentors in addition to pay?} If you want to give extra compensation to mentors you may think of support that would help them do their jobs better, like bicycles for transportation to and from meetings, badges to show community members when they are recruiting girls or organizing events, rain boots for the rainy season, etc. Some programs provide uniforms or an identity card, transportation reimbursement, mobile-phone airtime, certificates of completion, and other incentives. It is up to each program to decide what will be useful and feasible.

\section{Finding good mentors} How do you recruit mentors?

Program staff create a job advertisement and post/ circulate it around the community, passing it along to school headmasters, and NGOs in the community, and advertising in places like the local newspaper. Then they interview applicants and train a larger number than what is needed so that if "bad apples" emerge in the training, they can be dropped.

\section{What qualifications do you look for?}

There is no one-size-fits-all criteria since each program and environment is unique. Program staff try to recruit mentors who have completed secondary education, and who are literate and have some experience with $\mathrm{SRH}$ issues and facilitation. Ideally they have "progressive" attitudes on adolescent sexuality, but that is often hard to assess in an interview. Mentors should be enthusiastic and engaging toward girls. Some programs look for mentors who are especially vibrant or technologically advanced. Mentors should have the time required to dedicate to the program, and not be likely to leave the community during the program period.

\section{What is the profile required for mentors?} Young women between (usually) 18-30 years of age, residents of the community where they will mentor (or close to it), secondary school graduates (when possible), fluent in the local language, and willing to travel (to communities and to other cities for the training program) during the program period.

\section{What are the most important parts of the selection criteria? \\ Depending on the skills required by the program, education level can be important, and most programs find that ability and enthusiasm to work with girls is more important than prior experience.}




\section{What if you can't find mentors who meet the qualification requirements?}

In most communities, you will find girls or young women who meet the most important requirements to be a mentor, though it may take more work to find them in some places. In some especially difficult situations, the requirements can be stretched or the program can be modified by altering the content to suit the context.

I am above the stated age range for mentors but am passionate about adolescent-girl-related work; can I be considered as a mentor?

Yes, you might be considered, however your consideration would be based on your previous experience in this kind of program, or in a situation where we do not have enough other suitable applicants.

\section{What if a mentor becomes pregnant?}

Getting pregnant in itself is not a problem, and it does not mean the mentor should be expelled from the program or punished. Mentors can make the choice whether they want to stay in the program, and program staff can help them with the additional support needed to continue mentoring. The important thing is to keep the discussion with the mentor about pregnancy respectful and have a rights-based framing about making choices for herself. At the end of the pregnancy and right after birth, it is best to have an alternate mentor take over running the weekly group meetings so that the program is not interrupted.

\section{Training}

\section{What training do you provide?}

Most programs have an initial training of trainerstypically one to two weeks long and then monthly mentor meetings that serve as check-ins and opportunities for mini-refresher training on challenging topics. Opportunities for mock training sessions where mentors use role play to learn from each other is an important component of training. Mentor training should incorporate specific, step-by-step instruction on how to conduct activities. Pre- and post-training evaluations on knowledge are great tools for mentors to see how much they can learn in just one training, which can enhance their self-esteem and motivation.

\section{How long should a training workshop be?}

Do not overdo it; training workshops should be long enough to cover objectives and content, but short enough to keep mentors engaged and prepared until the next meeting. Trainings should be fun, interesting. and engaging. The training should model the type of participatory facilitation techniques expected from the mentors when running their girl group sessions. Mentors will also need time to rest and share free time. At the start they may need pre-set activities for social interaction. In Guatemala, for example, workshops last between three and four days and include educational movies, guest speakers, visits to museums, etc. During the first training they cover content for the first few months and study content for at least the following three months of sessions. Mentors will gather after a few months for a local meeting in which they will study the content for the pending sessions until the next training.

I have gone through a similar training in my previous volunteer work; do I still need to attend all the mentor training sessions?

Yes, you need to attend all sessions listed on the agenda. Even through programs may sound similar, certain components will be different. You need to ensure you are well equipped for the job.

\section{Cultural context}

What about adapting to different social and cultural contexts?

Mentors must understand the objectives of each session and the relevance of each suggested activity-that is, not only what the session aims to achieve but also how it is relevant to girls' lives. A key step is for mentors to plan sessions independently, as they will be doing in their communities, and adapting them to local needs, languages, illustrative examples, etc. 
Is talking about sexual health and reproductive health a taboo for mentors?

Yes, often at first. Typically, sexual and reproductive health topics are covered from the first training session through a variety of activities and resources. It is crucial that mentors feel comfortable talking about these topics before they can talk to girls groups about them. (It also is crucial that the people leading the training are comfortable.) Mentors' attitudes on the content matter: Since everything in the curriculum gets passed through the mentor before reaching girls, if the mentors don't believe it, even the best curriculum won't help. Sexual and reproductive health issues can be hard to grasp, so it is important to revisit them several times throughout the program.

\section{Keeping mentors engaged}

What elements are important to keep mentors in the program?

Pay is key because it relieves some of the pressure mentors receive from families if they are contributing less to their households because of their work as mentors. Mentors should also know their work is recognized and appreciated. Ongoing training can keep mentors engaged with their communities, and other mentors serve as a friendly network, keeping members motivated. A flexible rights-based approach can also help. For example, if mentors are pregnant or have children, they should be allowed to bring their children to trainings. Some mentors inevitably will move on to other jobs or drop out of the program because their family moves or they get married. Having a trained pool of mentors who can take over in case mentors leave the program is good practice to avoid disrupting the program.
Monitoring, evaluation, supervision, and support

\section{How can I monitor the mentors' work?}

The mentors can be monitored in different ways to meet different goals. Monitoring tools and regular check-ins can determine if girls are attending meetings, if the "safe space" is perceived as safe, and if the mentor is following the curriculum as expected. Girls can also provide feedback about their mentors. During periodic mentor meetings, mentors can share their challenges and successes. Even intensely monitored programs cannot provide constant feedback. Programs can compensate by creating opportunities for mentors to learn from each other.

\section{How can programs ensure mentors have the support they need?}

Mentors need ongoing supportive supervision to do their job well. One key is to have a strong referral system in place so mentors know when they should seek help from a supervisor or connect with other available services in the community for the program participants or themselves. During initial mentor trainings, mentors may do a community mapping of the support services available in their community, such as $\mathrm{SRH}$ services at the local clinic, psychosocial support, police victim support units, and gender-based violence referral systems. Information on the services available and their locations is critical for both the mentors and girls in the groups. All the work should not be left to the mentor-for difficult situations (like conflicts with parents or employers), they may need involvement from program staff.

\section{Is it unfair to visit mentors when they aren't expecting it?}

The purpose of an unannounced visit is not to surprise the mentor but to assess mentor performance in a typical session so supervisors can provide supportive guidance based on what is going well and how to improve. If mentors know program staff are coming, they may prepare more than usual so the session wouldn't be a true reflection of their usual preparedness and facilitation skills. Program staff need to know if mentors prepare for meetings and how they conduct their activities to provide feedback for performance improvement. 


\section{APPENDIX 2. POPULATION COUNCIL PROGRAM DESCRIPTIONS}

\begin{abstract}
Abriendo Oportunidades (Opening Opportunities)
The Population Council, in collaboration with local and international partners, launched Abriendo Oportunidades in Guatemala in 2004. The program reaches indigenous Mayan girls aged 8-9 with social support networks, role models and mentors, life and leadership skills, and hands-on professional training and experience to help them successfully navigate adolescent transitions. The program engages community leaders and trains girls to run community girls' clubs: safe spaces where they learn practical skills and assume leadership roles.
\end{abstract}

Evaluations in 2007 and 2011 found positive results for both mentors and girl participants, including:

- Higher educational attainment among mentors compared to national statistics

- Mentors who were more likely to remain unmarried and childless compared to the national average for girls their age

- More autonomy and self-efficacy among girl participants

The program began in a handful of rural communities in Guatemala and has since expanded nationwide, as well as to Belize and Mexico (where the program is called Abriendo Futuros). The program has expanded to include tutoring and is being adapted for girls in urban areas and for boys. The program is also working with partners in a Central American Learning Circle to promote and adapt the Abriendo Oportunidades model for other vulnerable girl populations in Costa Rica, El Salvador, Haiti, Honduras, and Nicaragua.

The Adolescent Girls Empowerment Program (AGEP) Implemented in partnership with YWCA Zambia from 2013-2016. The program reached over 10,000 vulnerable girls 10-19 years old in five urban and five rural sites across four provinces in Zambia. Girls were separated into groups of 10-14-year-olds, 15-19year-olds, and married girls/mothers. The program worked to build adolescent girls' social, health, and economic assets, providing them with key skills and opportunities to help them transition from adolescence to adulthood in a healthy way. AGEP was a cluster randomized controlled trial testing three combinations of interventions:

1. Safe Spaces groups, facilitated by a young, local female mentor, in which girls meet once a week over the course of two years for training on sexual and reproductive health, life skills, and financial education.

2. Safe spaces plus a health voucher that girls can use at contracted private and public facilities for general wellness and sexual and reproductive health services; and

3. Safe spaces, a health voucher, and a savings account that has been designed to be girl-friendly.

There was also a control site in which girls received no intervention.

\section{Adolescent Girls Initiative-Kenya (AGI-K)}

AGI-K was a randomized trial implemented in two sites: in urban Kibera, an informal settlement in Nairobi; and in rural Wajir, a remote, underdeveloped area in Kenya along the Northeast border with Somalia. AGI-K reached more than 6,000 girls age 11-15 between 20152017, and research was ongoing at the time of writing.

AGI-K tested the following four packages:

1. Violence Prevention, which includes community dialogues on the prevalence and persistence of violence against girls, coupled with funded community projects to address these challenges.

2. Violence Prevention + Education, which also includes a cash transfer conditional on school enrollment at the start of each term and regular attendance throughout the term.

3. Violence Prevention + Education + Health, in which girls meet in safe space groups once a week with a female mentor who delivers a health, life skills, and nutrition curriculum. 
4. Violence Prevention + Education + Health + Wealth Creation, in which girls also participate in additional financial education sessions integrated into the "safe space" curricula and open savings accounts or home banks.

AGI-K midline results show positive impacts for girls across a broad range of health, social, educational, and financial indicators in both Kibera and Wajir.

- In Kibera, AGI-K had significant effects on violence reduction, primary-school completion and schooling self-efficacy, sexual and reproductive health knowledge, social safety nets, financial literacy and savings behavior, and household economic status.

- In Wajir, AGI-K had statistically significant effects on primary-school enrollment, positive gender norms and self-efficacy, financial literacy, and savings behavior.

- AGI-K community programs and girls' savings are continuing to date, and the Population Council is exploring partnerships to extend the program.

\section{BALIKA (Bangladeshi Association for Life Skills, Income, and Knowledge for Adolescents)}

The BALIKA program was a four-arm randomized controlled trial that evaluated whether three skillsbuilding approaches to empower girls can effectively delay the age at marriage among girls aged 12-18 in parts of southwestern Bangladesh where child marriage rates are at their highest. More than 9,000 girls in 72 communities participated in the BALIKA program in 2014 and 2015. Communities were assigned to one of three intervention arms:

- Education support: Girls received tutoring in mathematics and English (in-school girls) and computing or financial skills training (out-of-school girls).

- Life skills training: Girls received training on gender rights and negotiation, critical thinking and decision making.

- Livelihoods training: Girls received training in entrepreneurship, mobile-phone servicing, photography, and basic first aid.

- Another 24 communities served as the control arm of this study: no services were provided in those communities.
All girls participating in the BALIKA program met weekly with mentors and peers in safe, girl-only locations, which helped girls develop friendships, receive training on new technologies, borrow books, and acquire the skills they need to navigate the transition from girlhood to adulthood.

Results found girls who were single at the beginning of the study were less likely to be married by the end of the study in each version studied. Compared to girls outside BALIKA communities, girls participating in the program were more likely to be attending school, have improved mathematical skills, and be earning an income. Beginning in 2017, the Population Council established partnerships with UNFPA, UNICEF, and the Bangladesh Ministry of Women and Children Affairs to expand the BALIKA program in new districts in Bangladesh.

\section{Biruh Tesfa (Bright Future)}

Biruh Tesfa reaches out-of-school adolescent girls in urban slums in Ethiopia, bringing them together with adult female mentors and providing nonformal education and education on HIV and life skills, as well as links to health services. The Population Council conceptualized this program based on research among Ethiopian adolescents and collaborates with the Ethiopia Ministry of Women, Children and Youth Affairs and its regional bureaus in Amhara, Addis Ababa, and Tigray to manage it.

Biruh Tesfa employs trained adult female mentors who go house to house to find eligible out-of-school girls between the ages of 7 and 24 and invite them to participate. This approach allows mentors to find girls who may otherwise be missed, such as child domestic workers who are largely confined to the home, girls with disabilities, and child sex workers. Once allowed to join, the girls meet regularly with the mentors and other girls in safe, public, girl-only locations donated by the kebele (local administration). At meetings, mentors provide basic literacy, life skills, financial literacy and savings, and education about HIV and reproductive health. A recent evaluation of the program found that girls in the area where Biruh Tesfa operated were more than twice as likely to report having social support than girls in a comparison area where Biruh Tesfa was not implemented. They were also twice as likely to score well on HIV knowledge questions, to know where to 
obtain voluntary counseling and testing, and to want to be tested. A further evaluation found that among girls who had never been to formal school who lived in the area where Biruh Tesfa operated, mean scores on reading and numeracy tests increased significantly. Similar improvements in test scores were not seen among girls who had never been to formal school who lived in a comparison area.

Biruh Tesfa has reached more than 75,000 out-ofschool girls in 18 cities across Ethiopia, and in 2019 is being expanded to reach 10,500 more girls.

\section{Filles Eveillées (Girls Awakened)}

Filles Eveillées was a 30-session program for migrant adolescent domestic workers in urban Burkina Faso that reached 375 girls between the ages of 11-19 employed in domestic service in Bobo-Dioulasso and Ouagadougou between 2011-2013. Filles Eveillées sought to increase domestic workers' opportunities and reduce their vulnerabilities by linking them to services; building adolescent girls' life skills, financial capabilities, and knowledge about health (including sexual and reproductive health); and expanding their social safety net (including access to peers and mentors).

To reach this isolated population, the program employed several strategies:

- going door-to-door to reach socially isolated girls and recruit them to the program;

- holding regular girls' group meetings to reduce girls' social isolation;

- $\quad$ using group meetings to build girls' protective skills and knowledge, giving them assets that cannot be taken away;

- linking girls to available health, financial, and psychosocial services in their communities; and

- conducting community-awareness sessions and home visits in each program community to build support for the program.

An evaluation of the program, the first asset-building program for girl domestic workers in Burkina Faso, found significant increases in the percentage of girls who reported:

- $\quad$ having a savings account;
- $\quad$ holding gender-equitable attitudes (such as disagreeing that men have a right to beat their wives);

- $\quad$ having a strong social safety net (including friends and people to turn to for advice); and

- $\quad$ knowing effective family planning methods and where to get them.

Filles Eveillées contributed tools in French for Routine Mentor Monitoring and Reporting written by mentors:

- Mentors' activity reports for each session (Canevas d'Appréciation des Sessions)

- Attendance data for each session (Tableau de Présence des Filles aux Sessions)

- Individual forms for home visits (Fiche Individuelle des Visites à Domicile)

- Mentor supervision sheets written by the Association Tié (Fiche de Supervision des Activités des Mentors).

These are available as the appendix to https://www.popcouncil.org/uploads/pdfs/2012PGY_ ProcessEval-FillesEveillees.pdf

The program has had important policy and program impact. The Burkina Faso Ministry of Social Welfare is using the approach and evidence generated by this program as it develops a strategy to better meet the needs of adolescent domestic workers. In Niger, UNFPA is using this approach to reach hundreds of thousands of girls.

\section{GirlsRead!}

In 2016, with the Forum for African Women Educationalists in Zambia (FAWEZA), a local NGO that works to improve gender equity in education, and Worldreader, an international NGO founded to address the chronic shortage of books in developing countries, the Population Council launched GirlsRead!, an education and empowerment program that is being evaluated through a randomized controlled trial. GirlsRead! combines three interventions: 
1. safe space groups for girls,

2. e-readers containing approximately 100 books, mostly fiction written by African authors, and charged using locally sourced solar panels, and

3. community engagement to bolster learning outcomes and reduce the likelihood that girls will leave school early. Mentor-led girls groups that foster nonfamilial social connections, engage girls in critical thinking about gender biases, and help them develop the social assets and confidence needed to progress to secondary school are employed throughout the program.

To evaluate the effectiveness of the interventions in enhancing literacy skills, improving performance on the primary-school leaving exam, and encouraging progression to secondary school, the Council is conducting a three-arm randomized cluster trial of approximately 1,200 girls in Grade 7 in 36 communities in Lusaka, Ndola, and Chingola districts. Surveys are administered before and after the intervention to adolescent girls in Grade 7, the last year of primary school. Girls are randomized into 3 study arms:

1. Group A: a safe space + e-reader + community engagement

2. Group B: a safe space + community engagement

3. Group C: a control

All three groups will receive the full intervention package during the second phase.

\section{NISITU (Listen to Me, Let's Grow Together)}

The NISITU program is a girl-centered approach to including both girls and boys in a community-based effort to promote equitable gender norms and reduce sexual and gender-based violence among adolescent girls and boys. NISITU includes girls and boys aged 10-19 in urban slums in Kenya. The program tests the idea that boys and young men are an important part of the ecology in which girls live, and that both girls and boys will benefit from a transformation in gender expectations. Girls and boys are grouped in singlesex groups of about 20-30 young people under the guidance of a mentor from the community. During weekly meetings in a safe space, the program covers a variety of topics related to sexual and reproductive health, gender norms and power, and economic strengthening. After the groups have been established for a few months, male and female groups have monthly meetings together during which they can discuss what they have been learning in their separate groups.

NISITU is using a quasi-experimental design in three communities: one in which both boys and girls have programs, one in which there is only a program for girls, and a control. Results from the study are expected in 2020.

\section{Safe and Smart Savings}

Safe and Smart Savings is a Population Councildeveloped program to help vulnerable adolescent girls build assets, support networks, and establish savings in order to break the grip of poverty. The program combines weekly group meetings facilitated by a female mentor, financial education, health and life skills education, and formal individual savings accounts. The program, which has been piloted and evaluated in Nairobi, Kenya and Kampala, Uganda has increased girls' social, health, and economic assets. Girls who participate are significantly more likely than other girls to have financial goals and accurate financial knowledge, to know about HIV and reproductive health, and to discuss financial issues with parents. They are also less likely to be sexually harassed.

The pilot phase of the program reached more than 12,000 girls in Kenya and Uganda between 2008 and 2012. The program was then expanded between 2012 and 2015 to more than 8,000 girls in Kenya, the majority of whom live outside Nairobi. 


\section{APPENDIX 3. LINKS TO FULL CURRICULA FROM PROGRAMS INCLUDED IN MENTOR TOOLKIT}

\section{Girl-Centered Programming}

- Tools and Resources for Girl-Centered Programming Publication, https://www.popcouncil.org/girl-centeredprogram-resources

- Girl-Centered Program Design: A Toolkit to Develop, Strengthen and Expand Girl-Centered Programs (2010), http://www.ungei.org/ files/2010PGY_AdolGirlToolkitComplete.pdf

- Building Girls' Protective Assets: A Collection of Tools for Program Design (2016), http://knowledgecommons.popcouncil.org/ departments_sbsr-pgy/559/

\section{Abriendo Oportunidades}

- Material didáctico para sesiones de trabajo (2018): https://knowledgecommons.popcouncil.org/ departments_sbsr-pgy/620/

- Abriendo Oportunidades para alcanzar mi plan de vida: Programa de 5 meses (2016):

- 8 a 13 años: https://knowledgecommons. popcouncil.org/departments_sbsr-pgy/549/

- 14 a 18 años: https://knowledgecommons. popcouncil.org/departments_sbsr-pgy/548/

- Abriendo Oportunidades Program: Integrated Curriculum Guide ( 8 to 17 years old)-Two-year cycle (2015):

- English: https://knowledgecommons. popcouncil.org/departments_sbsr-pgy/592/

- Spanish: https://knowledgecommons. popcouncil.org/departments_sbsr-pgy/615/

- Adapted for Belize (English): https:// knowledgecommons.popcouncil.org/ departments_sbsr-pgy/517/

- Herramientas para la formación de mentoras: https://knowledgecommons.popcouncil.org/ departments_sbsr-pgy/593/

- Abriendo Oportunidades para niños: https:// knowledgecommons.popcouncil.org/ departments_sbsr-pgy/616/
- Abriendo Oportunidades: sesión de plan de vida (2016):

- Cuadernillo Q'eqchi: https:// knowledgecommons.popcouncil.org/ departments_sbsr-pgy/617/

- Cuadernillo español: https:// knowledgecommons.popcouncil.org/ departments_sbsr-pgy/618/

- Sesión-Mi plan de vida: https:// knowledgecommons.popcouncil.org/ departments_sbsr-pgy/619/

AGEP

- Curriculum on Adolescent-friendly Health Services and Health Voucher Mechanisms: Facilitator's Training Manual (2015), https:// knowledgecommons.popcouncil.org/departments_ sbsr-pgy/587/

- Nutrition Education Curriculum for the Adolescent Girls Empowerment Program (2014), https:// knowledgecommons.popcouncil.org/departments_ sbsr-pgy/586/

- Financial Education Curriculum for the Adolescent Girls Empowerment Program (2013), https:// knowledgecommons.popcouncil.org/departments_ sbsr-pgy/585/

- Health and Life Skills Curriculum for the Adolescent Girls Empowerment Program (2013), https://knowledgecommons.popcouncil.org/ departments_sbsr-pgy/584/

\section{AGI-K}

- Adolescent Girls Initiative-Kenya: Health and Life Skills Curriculum, Wajir (2015), https:// knowledgecommons.popcouncil.org/departments_ sbsr-pgy/591/

- Adolescent Girls Initiative-Kenya: Financial Education Curriculum, Wajir (2015), https:// knowledgecommons.popcouncil.org/departments_ sbsr-pgy/590/ 
- Adolescent Girls Initiative-Kenya: Health and Life Skills Curriculum, Kibera (2015), https:// knowledgecommons.popcouncil.org/departments_ sbsr-pgy/589/

- Adolescent Girls Initiative-Kenya: Financial Education Curriculum, Kibera (2015), https:// knowledgecommons.popcouncil.org/departments_ sbsr-pgy/588/

\section{Filles Eveillées}

- Filles Eveillées: Programme pour les Adolescentes Employées de Maison-Guide du Mentor (2011), https://knowledgecommons.popcouncil.org/ departments_sbsr-pgy/582/

\section{GirlsRead!}

- Girls Rights: An Empowerment Curriculum (2018), https://knowledgecommons.popcouncil.org/ departments_sbsr-pgy/456/

\section{NISITU}

- NISITU (Nisikilize Tujengane): Listen to Me, Let's Grow Together Fact Sheet (2018), https:// knowledgecommons.popcouncil.org/departments_ sbsr-pgy/464/

\section{Safe and Smart Savings}

- Young Women: Your Future, Your MoneyWorkbook for Girls Ages 10-14 in Kenya (2011), https://knowledgecommons.popcouncil.org/ departments_sbsr-pgy/574/

- Young Women: Your Future, Your MoneyWorkbook for Girls Ages 15-19 in Kenya (2011), https://knowledgecommons.popcouncil.org/ departments_sbsr-pgy/575/

- Young Women: Your Future, Your MoneyWorkbook for Girls Ages 10-14 in Uganda (2011), https://knowledgecommons.popcouncil.org/ departments_sbsr-pgy/576/

- Young Women: Your Future, Your MoneyWorkbook for Girls Ages 15-19 in Uganda (2011), https://knowledgecommons.popcouncil.org/ departments_sbsr-pgy/577/ 


\section{ADDITIONAL RESOURCES AND READINGS}

Amin, S., J.A. Ahmed, M. Saha, M. Hossain, and E. Haque. 2016. Delaying child marriage through community-based skills-development programs for girls: Results from a randomized controlled study in rural Bangladesh. New York and Dhaka, Bangladesh: Population Council. https://knowledgecommons. popcouncil.org/departments_sbsr-pgy/557/.

Austrian, K., E. Muthengi, A. Wambugu, D. Ghati, and E. Kariuki. 2012. Safe and smart savings for vulnerable girls in Kenya and Uganda: The evolving model, lessons learned, and recommendations. New York: Population Council. https://knowledgecommons.popcouncil.org/ departments_sbsr-pgy/578/.

Jarvis, L. and G. Kabore. 2012. Process evaluation: The Filles Eveillées (Girls Awakened) program for migrant adolescent girls in domestic service in urban Burkina Faso. Ouagadougou: Population Council. https:// knowledgecommons.popcouncil.org/departments_ sbsr-pgy/581/.

Population Council. 2018. NISITU (Nisikilize

Tujengane): Listen to Me, Let's Grow Together. https:// knowledgecommons.popcouncil.org/departments_ sbsr-pgy/464/.

Salem, R., B. Ibrahim, and M. Brady. 2003. Negotiating leadership roles: Young women's experience in rural Egypt. Women's Studies Quarterly 31(3/4): 174-191. www.jstor.org/stable/40003326. 


\section{PopUlation COUNCIL \\ Ideas. Evidence. Impact.}

The Population Council helps strengthen the capacity of different actors to design, implement, and evaluate effective, scalable programs that build the health, social, economic, and cognitive assets of adolescent girls. To download the Council's series of practical tools and resources for girl-centered programming, visit: popcouncil.org/girl-centered-program-resources

\section{GIRL Center}

\section{FOR INNOVATION, RESEARCH. AND LEARNING}

The Girl Innovation, Research, and Learning (GIRL) Center generates, synthesizes, and translates evidence to transform the lives of adolescent girls. popcouncil.org/girlcenter 